HUGO AGUIRRE ARMELIN

\title{
CONTROLE DO CRESCIMENTO CELULAR EM MAMÍFEROS. CÉLULAS EM CULTURA COMO MODELO EXPERIMENTAL
}

Tese de Livre-Docência apresentada ao

Departamento de Bioquímica do Instituto de Química da Universidade de S. Paulo. 
Para Mari, Lia e Hugo 
o trabalho descrito nesta tese foi realizado durante os ültimos três anos na Universidade da California, em La Jolla, onde o autor foi ura "visiting research associate", no laboratório do Dr. Gordon Sato, Department of Blology. Duran te este período a Untversidade de são Paulo proporcionou- the licença com vencimentos em 1971 e 1972 e sem venctmentos em 1973; alēm disso apolo financeiro fol obtido da Fundação de Amparo à Pesquisa do Estado de São Paulo em 1971 (bolsa de es táglo no exterior), da Alfred Sloan Foundation, E.U.A., em 1972 (fellowship) e atravēs de um contato com o Department of Biology, em 1973. O autor agradece as oportunidades oferecidas por estas Instituições.

E preciso abrir um parēnteses nestes agradeclmentos formais para expressar a gratidão pessoal do autor ao genero so apoio dado por Gordon Sato, de cujos "grants" o autor se beneficiou largamente (U.S. Public Health Service, GM 17019; National Science Foundation, 15788GB e National Cancer Institute, CA 15503). Fases criticas do trabalho experimental foram realizadas graças à ajuda desinteressada de Susan Wolbers, uma têcnica de laboratório, com cuja colaboração o autor contou por mais de um ano e meio (1972 e 1973).

A forma final deste texto só fot atinglda graças à ajuda de Mari Cleide (minha esposa), à qual o autor agradece. 


\section{INDICE}

I. INTRODUÇÃO

II. CONTROLE DO CRESCIMENTO E DIVISÃO CELULAR: FATOS EXPERIMENTAIS E CONCEITOS PROSPECTIVOS

a. Cêlulas de cultura como modelos experimentais para o estudo do controle do crescimento e di visão celular

b. Um modelo probabilistico de "ciclo celular" 8

c. Previsões do modelo proposto 13

d. Fatores de crescimento: natureza e conceito 14

e. Fatores de crescimento em cultuxa de cēlulas de mamifero: conceito operacional e significado fisiológico

f. Programa para divisão celular: conceito ilusório ou idēia com valor heurístico 21

III. MATERIAIS E MÉTODOS 25

a. Animais 25

b. Linhagem de tumor transplantável 25

c. Iinhagens de células 26

d. Meios e condições de cultura 27

$\begin{array}{ll}\text { e. Soro } & 28\end{array}$

f. Fracionamento de soro e extração de esterōi$\begin{array}{ll}\text { des } & 28\end{array}$

g. Contagens de cêlulas e medidas de "eficiência de plaqueamento"

h. Processos de dissociação de tecicos para cultura primäria 31

i. Clonagem 32 


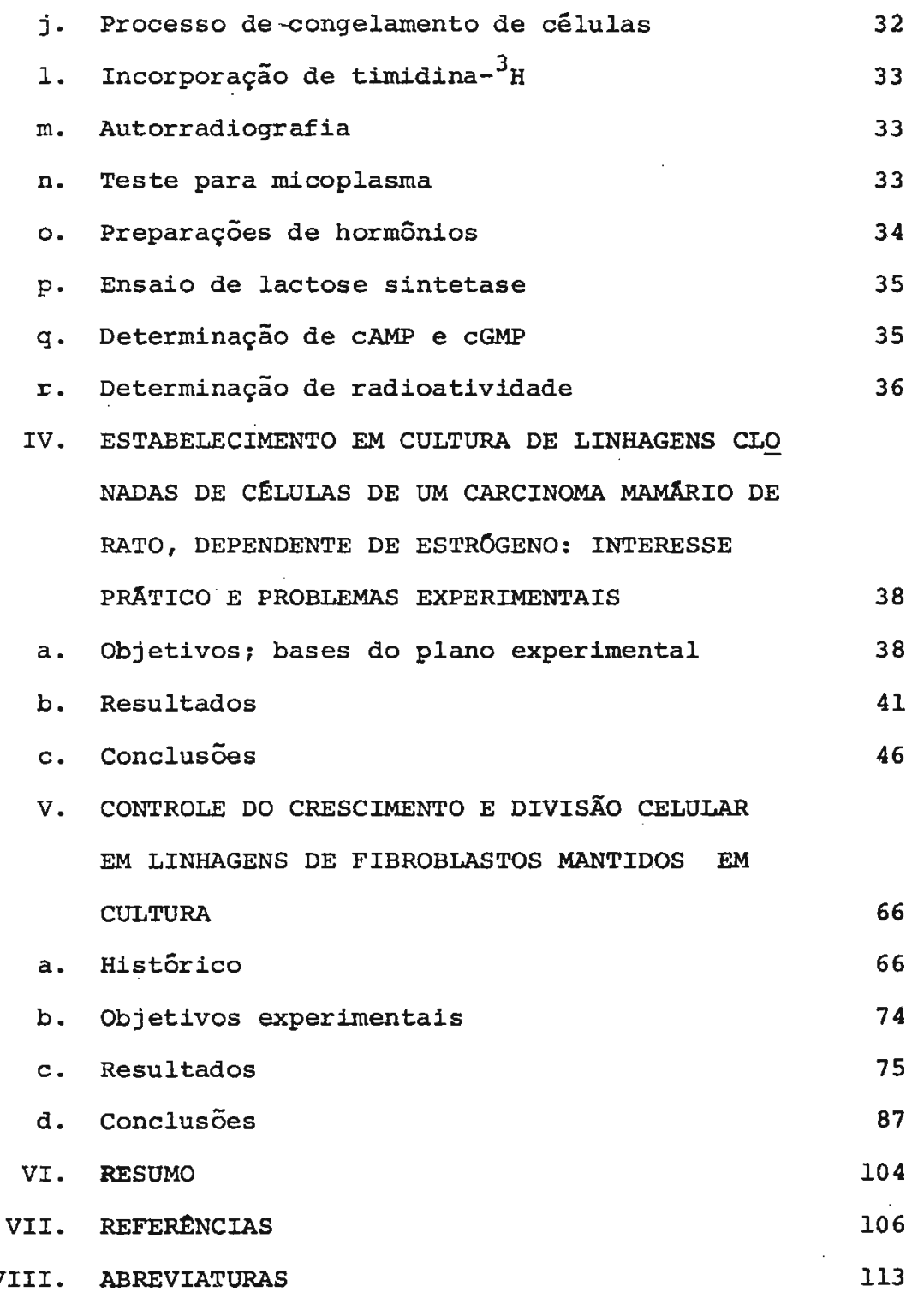




\section{INTRODUCุÃO}

A cultura de cêlulas de mamiferos tem, recente mente, exercido uma grande atração, motivada pela seguinte promessa: ser uma metodologia que permitiria a associação da anālise genëtica ao ataque bioquímico no enfoque aos problemas biolögicos bāsicos dos organismos superiores. Esta motị vação è muito comum entre jovens investigadores, ou mesmo in vestigadores experientes criados dentro da tradição da biolo gia molecular. Entretanto, $j a ̈$ os primeiros contatos com a cultura de tecido são suficientes para frustrar e, eventualmente afugentar a maior parte desta clientela. Simplesmente a cultura de cēlulas de mamifero tem ainda, muito de arte, e seu primitivismo está muito aquëm daquela metodolo gia, que muitos acreditam ser o processo, o qual eficiente mente dissecará os organismos superiores ao seu nivel celular. Não obstante, a cultura de tecidos, apesar de prática.muto antiga, oferece aquela atração de áreas novas, cuja utilidade prātica e arcabouço doutrinārlo ainda não foram totalmente definidos.

Um problema băsico da cultura de tecldo è o fe nômeno do estabelecimento de linhagens celulares. o equacio namento e definição deste problema não passou ainda do primeiro estāgio de descrição fenomenolö́gica. Fibroblastos de galinha, embora amplamente usados, nunca se estabelecem como linhagens estáveis em cultura; o estabelecimento não ocorre mesmo depois da transformação por virus. No outro extremo estão os fibroblastos de roedores, os quals invariavelmente đão linhagens permanentes, as quais em geral são heteroploi- 
seleção clonal deve ser possîvel selecionar as cēlulas portadoras dos "mecanismos regulatörios". Desta forma estamos abandonando como irrelevantes os problemas de "células diploi des","células normais", etc. que tanto tem complicado a literatura de cultura de tecido.

No Capĩtulo II nōs fazemos uma análise de propō sitos e apresentamos alguns conceitos preliminares, numa tentativa de fundamentação doutrinäria; as idēias bāsicas são,en tão, reduzidas a experiências realizāveis, cuja interpretação possivel é adiantada. O Capítulo III é uma descrição mínima de métodos. Os Capitulos IV e V reunem material essencialmen te experimental. Propositadamente, a estrutura foi planejada de tal maneira a permitir que os Capitulos II, IV e $V$ subsistam, independentemente, um dos outros. Tal propósito, foi to mado, na intenção de separar matēria inevitavelmente comprometida com o viēs das idéias elaboradas "a priori" (da qual - Capítulo II è abundante) de matéria experimental. Esta medida pareceu-nos adequada para preservar a validade empiri ca dos resultados independente das eventuais distorções de especulação.

Talvez nós pudessemos introduzir apropriadamente este trabalho, parodiando R. Pollack, o qual numa conversa de café em Cold Spring Harbor, o ano passado, me dizia mais ou menos isso:

If you take a yeast cell and you let it proliferate for a while, you get a bunch of yeast; on the other hand, if you take a mammalian cell and let it proliferate, you might get a man like you. If this fact does not convince you that a mammalian cell is different from a yeast cell you better go to work with yeast. 


\section{$-4-$ \\ II. CONTROLE DO CRESCIMENTO E DIVISÃO CELULLAR: FATOS EXPERIMENTAIS E CONCEITOS PROSPECTIVOS \\ a. Células de cultura como modelos experimentais para o estudo do controle do crescimento e divisão celular}

Praticamente células de qualquer tipo de tecido de mamifero podem ser colocadas em cultura apōs sua aispersão por meio mecânico ou enzimātico (tripsina, colagenase, hialuronidase, etc.). As culturas primārias oriundas destes processos podem exibir propriedades do tecido de origem por dias ou semanas e, en muitos casos, podem ser subcultivadas dando culturas secunaärias viäveis. Estas culturas de curta duração têm sido metodologicamente fundamentais para descobertas básicas: por exemplo, a descoberta e isolamento dos "hypothalamic releasing factors" (BURGUS et al, 1969) e do "sulfation factor" ou somatomedina (SALMON e DAUGHADAY, 1957; HALL e Van WYK, 1973; UTHNE, 1973). Entretanto, para o estu从 do do controle de crescimento, culturas de curta duração têm valor limitado, e o futuro desta abordagem experimental depen de do estabelecimento de linhagens de células permanentes, as quais, em cultura, exibem os "mecanismos regulatörios do cres cimento" que operam "in vivo". Portanto, a definição precisa do que entendemos por "mecanismos regulatörios do crescimento" tem valor critico; entretanto, como mostraremos a seguir, este não é um problema de simples solução.

Em culturas primárias e secundärias,seleção clo nal ocorre porque somente alguns tipos de células se dividem. 
Como regra geral, fibroblastos, do tecido conectivo, dividemse em cultura e usualmente crescem mais que qualquer tipo de cèlula, dominando, desta maneira, a cultura (SATo et al, 1960). Não obstante, è possivel isolar clones funcionais de outros tipos de células, desde que processos adequados de seleção sejam usados (BUONASSISI et al, 1962). Nos últimos dez anos tem sido possivel isolar um grande número de clones dife renclados e estáveis em cultura: cẽlulas hipofisárias secreto ras de ACTH (BUONASSISI et al, 1962), cëlulas adrenocorticaís sensiveis a ACTH (YASUMURA et al, 1966), células intersticiais de rato e camundongo secretoras de esteróis (YASUMURA et al, 1966a; SHIN et al, 1968), cēlulas gliais de rato (BENDA et al, 1968) cēlulas hipofisárias secretoras de hormônio de crescí mento e prolactina (YASUMURA et al, 1966b; TASHJIAN et al, 1968), células de neuroblastoma (AUGUSTI-TOCCO e SATO, 1969) e mioblastos (YAFFE, 1968). O isolamento e subsequente investigação destas linhagens de células demonstraram que mecanismos de ação hormonal (e presumivelmente qualquer mecanismo ao nível molecular) podem ser estudados usando-se clones de células permanentemente estabelecidos em cultura como modelos experimentais.

Em princīpio não hã limitações teōxicas ao 1solamento de linhagens de célúlas clonadas que retenham em cultura os "mecanismos regulatórios do crescimento". Na pxātıca, entretanto, a questão se complica. Sob as condições usuals de cultura primäria, fatores (fatores humorais desconhec1 dos, hormônios clássicos, etc.) que, presumivelmente, regulam o crescimento e a divisão celular, são limitantes o que leva ao aparecimento de uma forte seleção para células que es capam a regulação fisiológica do crescimento. 0 resultado 


\begin{abstract}
$-6-$
disto é que células estabelecidas em cultura são provavelmente independentes dos fatores fisiológicos de crescimento a me nos que precauções sistemäticas sejam tomadas para minimizar a seleção clonal inerente ao processo de estabelecimento em cultura. A abordagem a esse problema precisa ser cuidadosa, pois estamos lidando com argumentos circulares e facilmente poderiamos montar uma armadilha falaciosa: primeiro, nós queremos isolar células que exibem, em cultura, os "mecanismos re gulatōrios de crescimento" operativos "in vivo" (para permitir o estudo destes mecanismos de regulação); segundo, sabe mos que as condições de cultura levam a seleção de células, as quais escapam aos "mecanismos regulatórios de crescimento" (talvez todas linhagens de células estabelecidas, disponí veis atualmente, sejan deste tipo); e terceiro, nenhum dos "mecanismos regulatörios de crescimento" operantes "in vivo" pode ser concretamente definido no momento (nós simplesmente assumimos que eles devem existir, porque o crescimento dos tecidos é altamente regulado no animal). A conclusão ine vitävel a que se chega é, portanto, que qualquer manifestação, em cultura, dos "mecanismos regulatörio de crescimento" pode ser definido apenas operacionalmente. E, como corolärio: o isolamento de linhagens clonadas de células exibindo em cultú ra "mecanismos regulatörios de crescimento", tem que ser abor dado empiricamente, tendo o bom senso como guia.

TODARO e GREEN (1963) foram os primeiros a usar um processo sistemätico no isolamento de linhagens de células que mostram, em cultura, "mecanismos regulatórios de cresci mento". Estes autores desenvolveram então as linhagens de $f \underline{i}$ broblastos de embrião de camundongo com "inibição de contato".
\end{abstract}




\begin{abstract}
$-7-$
- fenômeno de "inibição de contato" foi tomado como uma manifestação dos "mecanismos regulatórios de crescimento" que nor malmente operam "in vivo", e as células que o exibem em cultu ra não desenvolvem tumores em hospedeiros apropriados (AARON SON e TODARO, 3968 ver histärico no Capítulo V, desta tese). Este tipo de célula, entretanto, pode ser transformada por pequenos vïrus de DNA, tal como SV40 ou polioma, abolindo a "inibição de contato", passando a célula a se comportar como uma célula cancerosa. Dadas estas propriedades interessan tes, estas linhagens de fibroblastos de camundongo têm sido um importante modelo experimental nos últimos dez anos. No Capítulo V desta tese nós analisaremos o comportamento deste sistema à luz dos resultados que temos obtido e dos conceitos e idēias, os quais introduziremos ainãa neste capítulo.
\end{abstract}

Além do desenvolvimento de linhagens de fibroblastos, uma outra alternativa para o estabelecimento de linhagens de células retendo "mecanismos regulatórios de crescimento" em cultura, tem sido tentada no laboratório do Dr. GORDON SATO. Neste caso a idéia tem sido tomar tumores dependentes de hormônio (ovarianos, mamärios, prostāticos,etc.) para crescimento em animais de laboratório(BISKIND e BISKIND, 1944; FURTH, 1968; IGLESIAS, 1970), e usā-los como fonte de células, cujo crescimento é dependente de hormônios trópicos (gonadotrofinas, estrōgenos, etc.), responsáveis pelo desenvolvimento dos tecidos parentais "in vivo". A meta final desta empreitada é obter linhagens clonadas e estáveis de cēlu las en cultura, as quais desenvolveriam. "tumores dependentes de hormönio" em hospedeiros apropriados e presumivelmerte $\underline{e}$ xibiriam em cultura "mecanismos regulatórios de crescimento" (pelo menos aqueles que envolvem o hormônio tröpico do qual 
depende o tumor). No Capítulo IV nōs apresentaremos os dados que obtivemos estudando o estabelecimento de uma linhagem de células a partir de un tumor mamărio dependente de estrōgeno para crescer em ratos.

b. Um modelo probabilistico de "ciclo celular" Tradicionalmente o "ciclo celular" tem sido representado da maneira esquematizada na Figura 1 . Este esquema envolve a idēia básica de que a célula passa por uma sèquência de eventos (metabólicos e citológicos) periódicos e deterministicos que caracterizam G1, s, G2 e M (BASERGA, 1968; MITCHISON, 1971; MAZIA, 1974). Tem sido indicado, frequentemente, por diversos autores, que o modelo formal de "c1 clo celular" (sequência de eventos periódicos e deterministicos) não se ajusta aos dados experimentais conhecidos, princi palmente os resultados cinēticos (NACHTWEY e CAMERON, 1968; STEEL, 1972; SMITH E MARTIN, 1973). SMITH E MARTIN (1973) mostraram as vantagens de modelos formais que envolvem pelo menos uma etapa ao acaso (não determinístico); nós também temos considerado a utilidade de um modelo deste tipo (ARMELIN, 1973; 1974, 1974b). O esquema da Figura 2 sumariza nossas idéias. Segundo nosso esquema, num caso geral, a população de células envolve três compartimentos: $R, P$ e T. As cêlulas do compartimento $\mathrm{R}$ estão no "estado celular fundamental" e elas somente saem de $R$ (transição 1 ou 2) por um processo ao acaso; este estado se caracteriza pelo bloqueio ("shut off") do "programa bioquīmico para a divisão celular" ou em outras palavras, as cēlulas estão em repouso. o "programa para divisão celular" consiste da sequência de reações bioquímicas e eventos citológicos precisamente determinada, a qual termina 


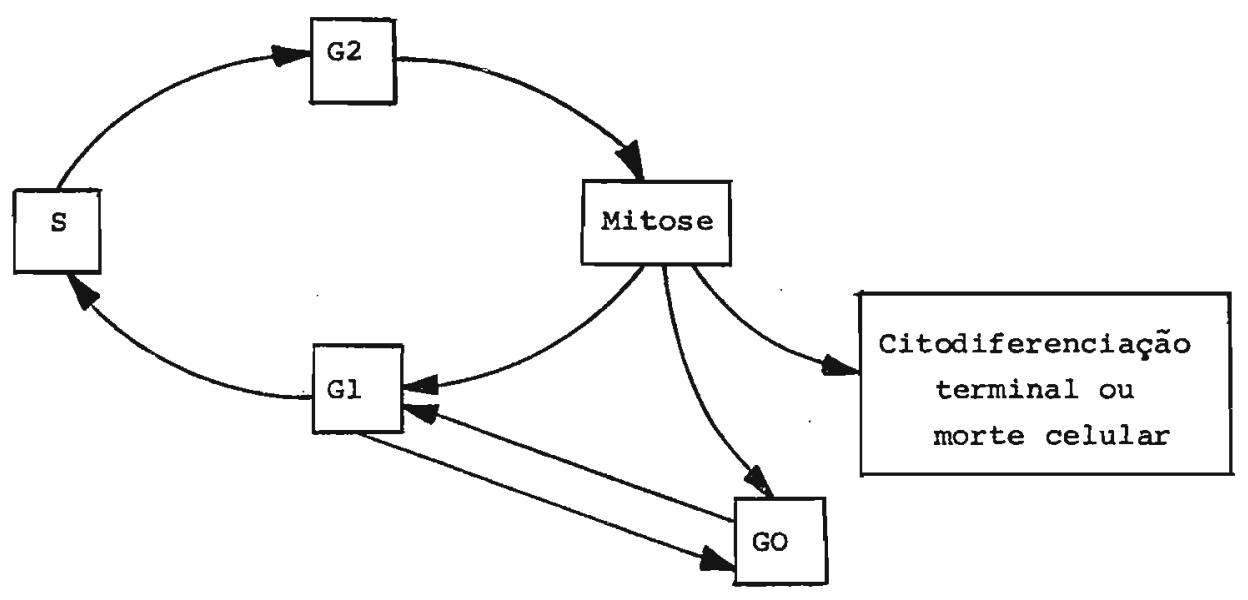

FIGURA 1 - Esquema geral do ciclo celular e dos compartimentos que compōe uma população de células. Os quadros representam os compartimentos das diversas fases celulares; as retas indi cam o sentido das transições que as células podem tomar de um compartimento para outro. As transições que deixam os compartimentos do ciclo de proliferação (isto é, Gl, S, G2 e M) podem ser reversiveis (para GO) ou irreversíveis (para citodiferenciação terminal ou morte celular). G1, S, G2 e M formam o "pool" de células em proliferação; Go forma "pool" de células em repouso, as quais retém a capacidade para divisão. GO é a fase originalmente introduzida por LAJTHA (1963) e larga mente usada na literatura com sentido muitas vezes varlável (BROWN; 1968; TEMIN, 1971; BASERGA, CASTLOW e RAVERA, 1973). 
Compartimento

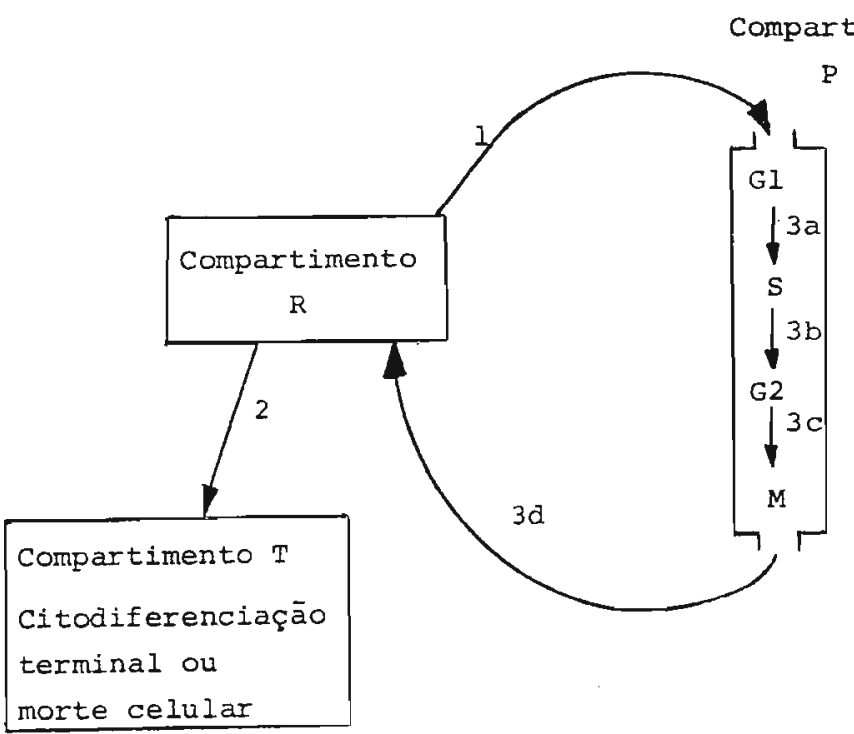

FIGURA 2 - Esquema geral dos compartimentos de uma população de células segundo o modelo probabilistico de ciclo celular pro posto. Os quadros representam os compartimentos da populaçao; Gl, S, G2 e M sāo subcompartimentos do compartimento P. As setas $1,2,3 a, 3 b, 3 c$ e $3 d$ indicam as transições que são permi tidas entre os compartimentos: somente as transições 1 e 2 são ao acaso. 
$-I I-$

com o evento final da divisão da célula em duas células filhas; isto é, trata-se da soma de todas as reações que caracterizam GJ. S, G2 e mitose. Células em $R$ podem sair e entrar em $P$ (compartimento das células em proliferação ou células comprome tidas com o "programa para divisão celular") iniciando o "pre grama para divisão celular". Como a saída de $R \bar{e}$ completamente ao acaso, uma dada célula permanece no estado $\mathrm{R}$ por um período indeterminado de tempo. Há somente una entrada para o compartimento P: o início de Gl(é preciso notar que Gl aqui es tá redefinido; na literatura a definição è ambigua, não havendo concenso).

E depois da mitose as células só tem uma saída: retornar ao estado $R$. O tempo que uma dada célula permanece em $\mathrm{P}$ é um periodo de tempo $\underline{t}$ bem determinado, onde $\underline{t}$ é o tempo necessärio para a célula atravessar G1, S, G2, M e finalmente retornar a $R$. As cēlulas do compartimento $T$ são incapazes de dividir, pois tomaram irreversivelmente o caminho da citodiferenciação terminal ou morte.

- "estado R" descrito no modelo acima tem apli cação geral, por exemplo, aplica-se a: i) "stem cells" como aquelas da linhagem eritrocitäria, as quais podem deixar $R$ em direção a P (Figura 2, seta 1) para replicação, ou podem tomar - caminho da citodiferenciação terminal (Figura 2, seta 2)para atingir o estágio final do eritrōcito; ii) hepatócitos, os quais retêm sua capacidade de replicar, embora sejam completa mente funcionais, e deixam $R$ para proliferar durante a regeneração do fígado; ili) células cancerosas não funcionais, em cultura ou animal, as quais saem de $R$ para proliferar ou para morrer. 
Para o investigador interessado nos "mecanismos regulatörios do crescimento", o modelo apresentado actma im plica que o crescimento de uma população de cëlulas depende de três parâmetros: i) a probabilidade $P_{1}$ com que uma célula deixa $R$ para replicação (transição para p); ii) a probabılidą de $P_{2}$ que determina a saída de células em $R$ no sentido de citodiferenciação ou morte; e iii) o tempo $t$, isto è, o perío do de tempo necessärio para uma dada célula atravessar Gl, $S$, G2, M e retornar a R. Se considerarmos: primeiro, que os resultados experimentais conhecidos indicam que a duração de $S$ e G2 não variam para um mesmo tipo de cëlula (NACHTWEY e CAME RON, 1968) e segundo, que a duração da mitose varia muito poul co, mesmo para tipos diferentes de cëlulas; necessariamente conclui-se que $t$ provavelmente não varia para um tipo particu lar de célula e portanto o controle do crescimento da população desta cēlula será exercido exclusivamente atravës de variaçöes de $\mathrm{P}_{1}$ e $\mathrm{P}_{2}$. Agora se particularizarmos para 0 caso de uma linhagem estabelecida de cẻlulas de mamífero em cultura, que não sofre citodiferenciação terminal e em condiçōes tais que morte celular è negligenciável, o crescimento da população será função somente de $\mathrm{P}_{1}$, a probabilidade da transição do "estado $R^{u}$ para a "fase $\mathrm{P}^{\text {" }}$

Assumindo que a reduçāo efetuada acima ē realis ta podemos usar culturas de células como modelos experimentais e estudar como variaçöes das condiçōes ambientais afetam $\mathbf{P}_{1} e$ como,portanto, controlam a proliferação celular. Neste ponto é importante reunir as previsōes do modelo proposto que podem ser facilmente testadas por experiências simples. 
c. Previsões do modelo proposto

A primeira previsão derivada do modelo è que nōs devemos ser capazes, manipulando as condições ambientais, de levar a célula ao "repouso" (estado R). A caracterização míni ma do "estado de repouso" inclu1: 1) a população não aumenta em nümero; i1) a viabilidade é mantida e iil) a sintese de DNA é ausente ou negligenciāvel. A segunda previsão implica que nós devemos ser capazes de induzir células em repouso a entrarem na "fase prollferativa". O padrão desta transição deve se caracterizar por: i) a sintese de DNA se inicia apös um "lag", isto é, Gl; ii) a duração de Gl è independente do número de células que iniciam sintese de DNA; iii) a variação da frequêncla de celulas iniciando sintese de DNA (a qual mede a magnitude da resposta), depois de um perlodo de tempo no minimo igual a Gl, oscila entre 0 e 1008 da população; iv) o conpromisso bioquímico da célula para o processo replicativo, tor na-se num certo ponto, independente do estímulo inicial; este "ponto sem retorno" deve ser experimentalmente definível.

E razoãvel considerar como as condições amblen tais regulariam a transição entre o "estado $R$ " e a "fase $P "$, embora isto não venha trazer nenhuma alteração às previsões an teriores. De uma maneira geral, os fatores ambientais podem exercer controle negativo (ação inibitória) ou positivo (ação estimulatöria) sobre a proliferação celular. Parece-nos mais atraente a idēia de controle positivo; este viés, entretanto, não exclui a possibilidade da existência de controle negativo. Não obstante não hã motivos para preocupaçōes pois ambas as possibilidades podem ser distinguidas experimentalmente. Fato res que estimulam a proliferação (controle positivo) incluiria 
$-14-$

mos na classe geral de "fatores de crescimento". As previsões do modelo, descritas acima, fornecem uma base racional para a identificação experimental e ensaio quantitativo de "fatores de crescimento". Mas, antes de particularizarmos para o caso de células de namifero em cultura, é interessante levarmos avante uma moderada especulação em torno da possível natureza dos fatores de crescimento.

d. Fatores de crescimento: natureza e conceito E importante notar que o meio intracelular é extremamente complexo, e um controle fino da economia geral, ao nivel bioquimico, è fundamental para manutenção da estabilidade do sistema. Por outro lado a replicação impõe uma alta demanda na economia celular, porque o sistema precisa duplicar a si mesmo para se dividir. Além disso a replicação è um processo de tal complexidade, que sua parada a meio caminho pode ameaçar a sobrevivência da célula. Assim, é provável que a cēlula não se comprometa com o processo repli cativo, a menos que possua os "suprimentos" necessários para completá-10. En vista disso é razoăvel se esperar que da se leção natural tenha, muito cedo, resultado mecanismos de controle, pelos quais, niveis criticos de metabólitos chave servem como "reguladores intracelulares" da iniciação do pró cesso replicativo. Mecanismos băsicos e simples, dessa natú reza, sem düvida, aparecem tanto em organismos inferiores co mo superiores. Entretanto, o meio extracelular de organismos inferiores e superiores é muito diferente. Mecanismos de controle adicionais certamente apareceram, os quais foram su perpostos à economia intracelular básica; estes controles são necessārios para garantir regulação adequada da proliferação 
celular de organismos tão diversos quanto levedura e mamiferos. Organismos unicelulares de vida livre, como bactēria ou levedura, proliferam em função da disponibilidade de nutrientes no meio ambiente. Eles crescem rapidamente em meio rico e lentamente em meio minimo, pois nesta ūltima situação, vias metabólicas, desnecessärias em meio rico, tem que ser ativadas. Por outro lado, para um mutante auxotrófico, crescendo em qualquer meio, a substância a qual elé é inca paz de sintetizar se torna fator limitante para prolifera ção e consequentemente, por definição, a substância è um "f̣a tor de crescimento". Concluimos disto que para microrga nismos, fatores de crescimento são nutrientes. Este fato tor na as cēlulas capazes de responder rapidamente as variações incontroláveis do suprimento nutricional do meio, otimi zando tanto a sobrevivência como a velocidade de prolifera ção.

Em organismos superiores, a célula de mamifero por exemplo, enfrenta condiçōes bem aiferentes: o meio interno é altamente controlado física e quimicamente, para eví tar variaçōes fatais de $\mathrm{pH}$, temperatura, glicose, etc., fora do estreito intervalo fisiológico. Neste sistema altamente regulado, a alocação e utilização de nutrientes são controla das por hormônios clássicos, tal como insulina, e talvez tam bém por outros fatores de natureza hormonal mas ainda desconhecidos. Estes fatores desenvolvem suas funções (pelo menos parcialmente) regulando a atividade de sistemas de transportes, especificos para nutrientes, localizados na membrana celular externa; o papel destes sistemas de transporte da membrana é mediar a disponibilidade de nutrientes no meio intracelular. Some-se a isso o fato de que mamiferos exibem 
$-16-$

un alto grau de controle da proliferação celular: por exem plo, cēlulas de fígado raramente dividem, mas todas são po tencialmente capazes de dividir; eritrócitos maturam conti nuamente, limitados somente pela proliferação das células colunares ("stem cells"); a resposta imunológica envolve uma onda de divisão em linfócitos do tipo B. 0 modo de contro le destes processos especificos para células è questão, ainda, totalmente aberta à especulação. Seguindo nossa linha de raciocinio poderfamos propor uma hipótese, segundo a qual cada tipo de célula tem um fator especifico, cuja função é disparar (controle positivo) o "programa para divisão celular" (regulando a probabilidade da transição do "estado $R^{\prime}$ para a "fase $P$ "). Este fator só é efetivo se os nîveis Intracelulares dos nutrientes forem adequados à replicação; por outro lado, os niveis intracelulares dos nutrientes são dependentes dos "reguladores extracelulares dos sistemas de transporte". Em suma a proliferação celular seria função ex clusiva de "reguladores especificos de proliferação" ("fato res de crescimentos": uma classe de reguladores endócrinos), cuja ação pode ser modulada por "reguladores dos sistemas de transporte". O teste direto das implicações desta hipôtese com experiências "in vivo" é dificil, ou mesmo impossivel atualmente, por dificuldades essencialmente metodolögicas. Com cultura de células as condições experimentals são favorăveis, mas neste ponto nos esbarramos nos problemas levantados já no início deste capitulo: as condições atuais da cultura de células são ainda primitivos, assim como hã falta de uma estrutura doutrinária adequada a interpretação dos resultados. Não obstante, continuando com a anälise con ceitual que estamos levando a cabo, vamos tentar propor um 
critério prätico para abordarmos com experiências simples e as questões elaboradas anteriormente.

e. Fatores de crescimento en cultura de cēlulas de mamifero: conceito operacional e significado fisiológico

O melo de cultura para cēlulas de mamifero con têm: i) uma parte quimicamente definida que, teoricamente, de ve fornecer os nutrientes essenciais de baixo peso molecular em quantidades adequadas; e ii) uma parte complexa que é soro. E errado acreditar que um apropriado enriquecimento nutricional do meio sem soro levaria ao crescimento de qualquer tipo de célula. Isto seria negar a existência de "regu ladores extracelulares", os quais, è razoāvel admitir, são fornecidos pelo soro. A existência de algumas linhagens de cēluias que crescem em meio quimicamente definido não refuta esta afirmação. Tais linhagens são, ou cēlulas que sintẹ tizan reguladores como as células de figado de rato de coon (DULAK e TEMIN, 1973), ou são células especiflcamente selecionadas para crescer independente de "reguladores".

Em bases puramente experimentais pode-se ado tar a seguinte definição operacional de "fator de crescimento": una substāncia que limita o crescimento quando presente em concentrações limitantes. Parece-nos razoāvel assumir que, normalmente, nutrientes extracelulares não são limi tantes de crescimento na situaçāo "in vivo" sendo a prolife ração essencialmente dependente de "reguladores" seja qual for sua natureza e mecanismos ("reguladores dos sistemas de transporte da membrana", "reguladores especificos da prolife 
ração celular", etc.). Nas condições de cultura, entretanto, a situação é bastante diferente: nutrientes extracelulares po dem ser limitantes de crescimento, seja devido a deliberada manipulação da composição do meio ou a deficiências do meio, das quais ainda não se suspeita. A definição operació nal de "fator de crescimento" sugerida acima, não distingue entre nutrientes extracelulares e "reguladores", mas de algu ma maneira é preciso distingui-los experimentalmente. Mais uma vez, é razoável admitir que os efeitos fisiológicamente significantes são aqueles devido aos "reguladores" (tendo em vista a caracterização dos "mecanismos regulatörios do cresci mento"), enquanto que os efeitos devido a baixos níveis de nu trientes extracelulares são essencialmente um fenômeno de cul tura de célula. Dadas as considerações anteriores era fundamental que estabelecessemos um critērio prātico para a busca e caracterização dos "reguladores" de crescimento.

Estão tmplícitos na idēia de "reguladores" algu mas propriedades que podem ser definidas "a priori". Os "reguladores" seriam transmissores de uma mensagem ou sinal e exerceriam sua ação interagindo com receptores específicos.Fi sicamente a interação entre "regulador" e "receptor" seria do mesmo tipo enzima e substrato e o número de receptores deve ria ser pequeno. Conclui-se que as cëlulas que "responderiam" a um dado "regulador" possuiriam por ele alta "afinidade" e baixa "capacidade", propriedade que pode ser medida quantitativamente ao nivel celular ou subcelular, desde que o "regula dor" seja isolado e purificado. Mas, inicialmente, estávamos num estāgio anterior: os "reguladores" da proliferação celular eram postulados e portanto não tinham ainda sido identifi 
$-19-$

cados e muito menos isolados. Neste estāgio o mais importante era a determinação quantitativa de um regulador desse tipo, fase inicial absolutamente necessäria na sua procura. 0 efei to final do regulador $\bar{e}$ a divisão celular, portanto o ensaio de atividade deve medir "quantidade" de divisão seja direta mente, contando células, ou indiretamente, medindo sintese de DNA, sintese de proteína, etc. Levando em conta que deve existir una relação simples entre o efetuador (ou o "regula dor") e a resposta e dadas as propriedades assumidas para o regulador, o resultado mais simples a ser esperado para a curva de resposta em função de concentração de regulador è uma curva do tipo da de Michaelis para enzima. A parte li near da curva determina o intervalo de concentração ütil do "regulador", cujo intervalo deve ser "fisiológico". E razoável assumir que o "intervalo fisiológico" seja semelhante ao observado para os hormōnios clāssicos, isto é, o plateau da curva já deve ser atingido em concentrações de $10^{-11}$ a $10^{-10}$ M. Isto dá uma medida das atividades especificas a serem esperadas. Estas premissas serão muto üteis e de fácil aplica ção para determinar se os hormônios clássicos (cujos isolamen tos e purificações já foram feitos) tem atividade de "regulador de proliferąão".

Na prātica a identificação de "reguladores" e o desenvolvimento de ensaios de atividade è severamente limitado pelas dificuldades técnicas de fracionamento do soro. Em nossa experiência a abordagen prätica a esse problema tem envolviōo: i) uso de fracionamentos padrão que permitem o fracionamento parcial do soro (por exemplo, o fracionamento de Cohn); ii) uso de alguns tratamentos desenvolvidos por nōs 


$$
-20-
$$

(ver Materiais e Métodos); iii) uso de soro de animais com glândulas extirpadas (hipofisectomizados, ovariectomizados, a drenalectomizados e tireoldectomizados).

o ensaio é direto e simples quando é possível de senvolver condiçōes nas quais as cēlulas entram em repouso ("estado R"), condição em que sintese de DNA è nula. Neste caso o ensaio pode ser feito pela medida da sintese de DNA atravēs da incorporaçāo de ${ }^{3} \mathrm{H}$-timidina (ver CapItulo V, ensaio fibroblastos 3T3). Nos casos em que empiricamente não se consegue obter as células em repouso, o compromisso è medir a varıação do tamanho da população com o tempo (ver capítulo IV, ensaio para células de rato).

Independentemente das dificulaades de cada caso - procedimerić padrão que adotamos envolve as seguintes etapas: i) manipulando-se o soro, (concentração, fracionamento, animais operados), desenvolve-se um meio no qual o crescimen to é sub-ótimo, e ii) adicionam-se substâncias ou prepara ções complexas a esse "meio minimo" para fníaiar quantitativa mente "atividade promotora de crescimento".

Hormônios puros (proteinas como insulina, FSH IH e prolactina; esteróides como estradiol, testosterona, tes tosterona desidrogenada, hidrocortisona e progesterona), preparações de hormōnios parcialmente purificadas (obtidas do programa de distribuição do N.I.H. ou comercialmente) e extra tos diversos de vários tecidos tem sido testados para "atividade promotora de crescimento". Atravës de ensaios quantitativos adequados curvas de atividade em função de concentra ção tem sido geradas. Os resultados experimentais tem sido julgados pelo seguinte critério: i) atıvidade de hormônios 


\begin{abstract}
$-21-$
puros è considerada fisiologicamente significante somente se for observada nas concentrações fisiológicas do hormônio; ii) atividade observada a concentrações altas, não fisiolōgicas, é descartada como não significante se a pureza da preparação estã acima de qualquer suspeita; iii) atividade com con centrações altas de preparações impuras de hormônios conheci dos, è sujeita a estudos posteriores no sentido de verificar se a espēcie ativa è um contaminante; iv) atividade devi da a um contaminante é tomada como uma trilha interessante que pode indicar a existência de un fator fisiologicamente atıvo e ainda desconhecido; $v$ ) atividade significante observada em extratos de tecido e investigadas visando cair num dos casos anteriores. Com este exerclcio experimental nos foi possi vel demonstrar que "reguladores da proliferação celular" exí tem de fato, pelo menos en cultura de cēlulas de mamífero(ver ARMELIN, 1973 e Capitulos IV e V desta tese). Se tais reguladores são ativos "in vivo", da mesma maneira como o são em cultura, è uma questão ainda a ser respondida. Porém, inde pendentemente disso, estes reguladores jã estão sendo üteis pa ra investigar os "mecanismos regulatórlos do crescimento" em cultura de cēlula, testando algumas das hipóteses levanta das neste Capitulo.
\end{abstract}

f. Programa para divisão celular: conceito ilusō rio ou idéia com valor heuristico

Na seç̧ão b deste Capitulo fol introduzida a idēia de "programa para divisão celular"; programa este que não pode, atualmente, ser descrito na forma simples de um mapa metabōlico, pois não hă conhecimento bioquimico disponivel para tanto. A idēia porēm, parece intuitivamente correta e 
talvez as evioências experimentais mais interessantes em seu favor não sejem biogúnicas, mas sim os resultados obtidos por HARTWEI e colaboradores (1973) na análise genética do ciclo celular de levedura.

A Figura 3 apresenta. um quadro da distribuição de alguns eventos bioquímicos, ao longo do ciclo celular de cēlulas de mamífero. Não se trata de um levantamente extensi vo da literatura, pelo conträrio é uma composição de informacōes selecionadas para os propósitos deste texto; o quadro iñ clui tanto dados ainda a serem confirmados (eventualmente controvertidos), como dados solidamente estabelecidos pela ex periência. Os pontos a serem destacados são: i) indiscutivel mente certos eventos estão circunscritos a partes restritas do ciclo; ii) no inicio de Gl há manifestaçōes de alteração espẹ cifica de transporte, variação dos níveis dos nucleotidios cíclicos, rearranjo estrutural de membrana e ativação de novos genes; iii) os eventos do inicio de Gl são os mais interessantes, pois è neste periodo que, aparentemente, a parte crítica do controle do crescimento e divisão está operando; daí ser atraente a idéia de procurar os "mecanismos regulatórios do crescimento" entre as "reaçōes de iniciação de Gl".

A dificuldade séria no trabalho com as reações iniciais de GI está em que elas ocorrem num intervalo restri to de tempo (10 a 20 minutos). Não tem sido possível, ainda, estabelecer relaçāo de causa e efeito (ov outra qualquer) entre estas reaçōes. Plém disso a falta de conceitos gerais, métodos e modelos celulares padronizados, frequentemente impe dem a comparação de resultados. Parece-nos que a orientação que temos dado ao nosso trabalho, seja do ponto de vista 
$-23-$

conceitual ou metodológico, oferece promessas de progresso nes sa ärea. 


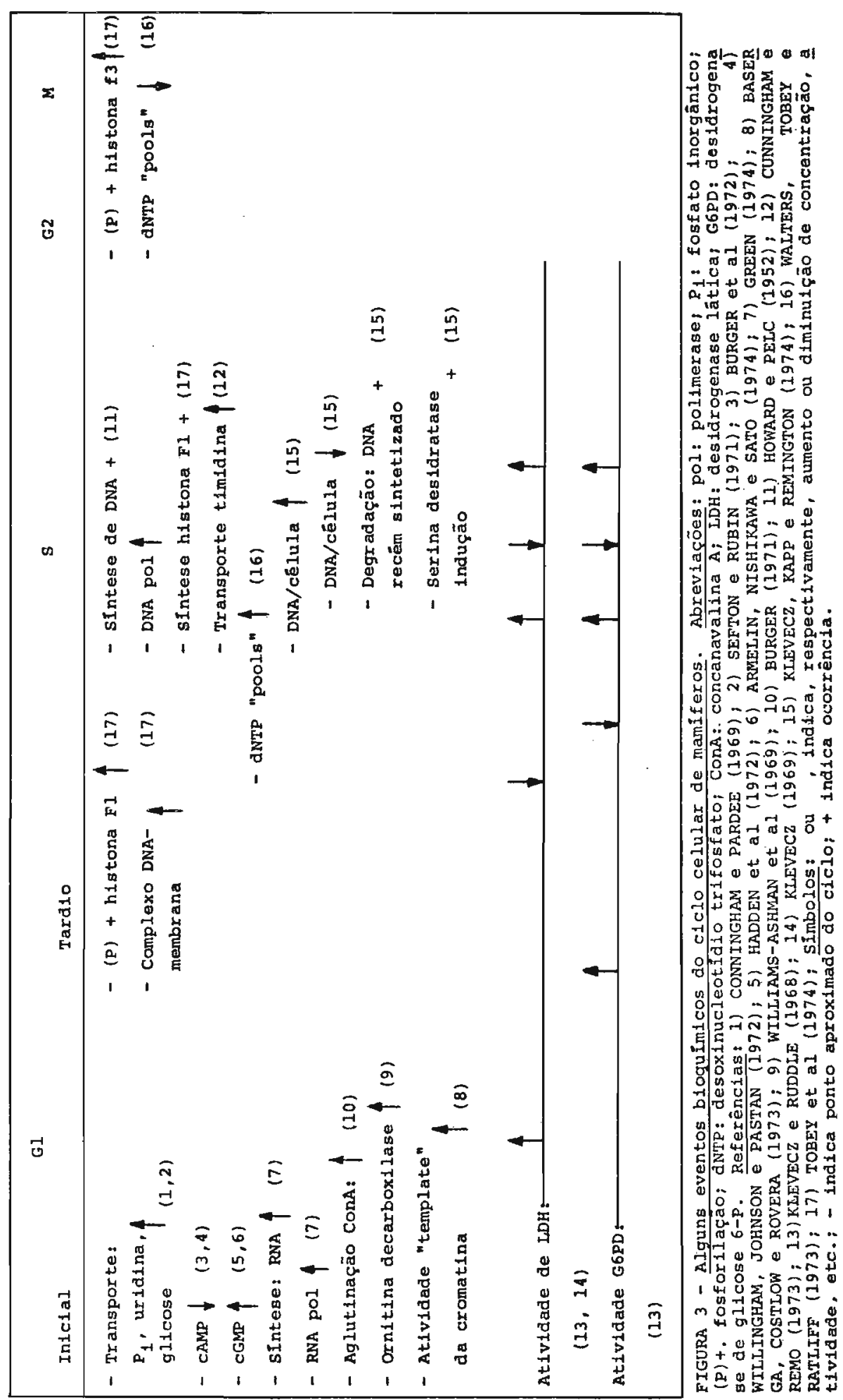




\title{
III. MATERIAIS E METODOS
}

\begin{abstract}
a. Animais
Foram usados ratos de IInhagem AxC (IInhagem cruzada entre irmãos há multos anos, ver IGLESIAS, 1970), aḍ quiridos comercialmente ainda jovens e mantidos em gaiolas isoladas. Animais hlpofisectomizados eram comprados jä operados: ovariectonias e adrenalectomias exam feltas no prōprio laboratório.
\end{abstract}

b. Linhagem de tumor transplantãvel

Obteve-se do Dr. R. Iglesias, Chlle (ver IGLESIAS, 1970), uma linhagem de carcincana mamärio transplantá vel de ratos $\mathrm{AxC}$, o qual só se desenvolvia em animais com al tos nivels de estrōgeno; machos ou fêmeas normais não desenvolviam tumores. O tumor era branco-amarelado, sólldo, mole e raramente necrosado; não apresentava indicações de metāsta se quando injetado sob a pele, alcançando grande tamanho antes de causar a morte do animal (tumores de 50 a 60 gxamas foram comuns em animais alnda vivos); extbla (principalmente quando picado) un "suco" ou secreção leitosa, o que alguns oncologistas experimentais interpretam como indicação de tumor mamärio funcional (sintese de lefte). Transplantes eram efetuados, injetando-se sob a pele $0,2 \mathrm{ml}$ de uma suspensão obtida por picagem do tecido com tesoura, numa solução sali na-fosfato. Níveis altos de estrógeno eram conseguidos pelo implante de pastilhas de $10 \mathrm{mg}$ de estradiol sob a pele do animal, o qual era aplicado ao mesmo tempo que se fazia 
$-26-$

transplante de tumor. Andmais que recebiam estradiol (se transplante de tumor) apresentavam diversas anomalias: acen tuada perda de peso; decréscimo do crescimento em jovens; a. trofia de gônadas em machos; desenvolvimento de glândulas mạ mārias e sobrevida de 4 a 6 meses após o implante. Acrescer te-se a 1sso que o estradiol tambēm leva a hiperplasia da hipöfise (IGLESIAS, comunicação pessoal), embora nossos animais não tenham sido examinados para isso. Animais hipofi sectomizados sobreviviam mito menos ao implante, de una semana a um mês de sobrevivência; durante este periodo de sobrevivência dos hipofisectomizados crescimento do tumor nunca foi observado. Trata-se portanto, provavelmente de tumor cujo crescimento depende de secreção hipofisāria.

\section{c. Linhagens de células}

Diversas sublinhagens de fibroblastos $3 \mathrm{~T} 3$, os quais são provenientes de embriōes de camundongos suiços e estabelecidos por TODARO e GREEN (1963), foram usados: 1) obtida do laboratório do Dr. G. Sato (University of Califor nia, La Jolla); 2) obtida do laboratōrio do Dr. R.W. Holley (Salk Institute); 3) obtida da American Type Culture Colection; 4), obtida do laboratório do Dr. D. Cunningham (Dniversity of California, Irvine), todas estas sublinhagens foram mantiaas isoladas. Uma linhagem de $3 T 3$ transformada por virus (SV40) fal obtida do laboratörio do Dr. R. Dulbecco(Salk Institute), sendo designada sV3T3. Uma amostra da linhagem WI38 de fibroblastos humanos (originalmente desenvolvida por HAYFLICK e MOORHEAD (1961)) foi obtida do laboratório do Dr. P. Price (University of California, La Jolla); es ta linhagem foi usada entre a. $25^{\text {a }}$ e $40^{\text {a }}$ passagem ou subcult 
vo. Estas célolas, que crescem em monocamadas aderidas a superficie de vidro ou plástico, foram rotineiramente subcultivadas antes de chegar a confluêncla. O melo de cultura para manutenção dos estoques foi CFB (ver meios de cultura) e normalmente estogues reserva de cada linhagem forma mantidos em nitrogênio İquido.

\section{d. Meios e condiçōes de cultura}

Os meios de cultura normalmente possuem uma parte qumicamente definida e uma parte complexa, que é soro; eventualmente adiciona-se também un tampão argânico para ajudar a estabilização do pH. Neste trabalho a parte quimicamen te definida foi sempre o meio minimo de Eagle modificado por Dulbecco (DME), mas com apenas $1,2 \mathrm{~g}$ de bicarbonato de sōdio por litro; o meio era comprado em mistura pronta, em pō, de Grand Island Biological Co. (GIBCO), Nova York. Melo dito $10 \%$ em soro significa $90 \%$ de DME mais $10 \%$ em soro, volume a volume. o meio padrão (CFB) para crescimento de estoque teve a seguinte composição: $85 \%$ de DME, $12,5 \%$ de soro de cavalo (C) e 2,58 de soro de feto bovino (FB), o qual foi o meio mais rico usado agui. Um soro muito usado neste trabalho fol soro de vitelo (V) e $108 \mathrm{~V}$ ou $18 \mathrm{~V}$ significa 108 soro de vitelo mais 908 DME ou 18 de soro de vitelo mais 998 DME, respectivamente. Frequentemente o tampão AEPEs lácido N-2-hidroxie tilpiperazina-N'-2-etanosulfônico) fol usado no melo na concentração de $15 \mathrm{mM}$.

As cēlulas eram cultivadas em placas de petri ou frascos de plástico, especialmente tratados para cultura de tecido, fornecidos por Falcon Plastics, California. As cultu 
ras eram mantidas a $37^{\circ} \mathrm{C}$, em câmara úmida e atmosfera de 58 de $\mathrm{CO}_{2}$ e 958 de ar.

Para subcultivo as cêlulas eram destacadas da placa por tripsinização atravês da seguinte solução: $\operatorname{NaCl} 8,2$ $\mathrm{g}, \mathrm{KCl} 0,2 \mathrm{~g}, \mathrm{Na}_{2} \mathrm{HPO}_{4} \cdot 7 \mathrm{H}_{2} \mathrm{O} 2,16 \mathrm{~g}, \mathrm{KH}_{2} \mathrm{PO}_{4} \mathrm{O}, 2 \mathrm{~g}, \mathrm{Na}_{2} \mathrm{EDTA} \cdot 2 \mathrm{H}_{2} \mathrm{O}$ $0,29 \mathrm{~g}$, fenol vermelho $15 \mathrm{mg}, 1 \mathrm{~g}$ de Tripsina (1-300, Nutri tional Blochemicals) dissolvidos em l litro de àgua bidestila da.

\section{e. Soro}

Soro era adquirido comercialmente de GIBCO, Nova York ou Flow Laboratories, Colorado; diferentes partiaas podem variar consideravelmente entre si e não existe ainda um processo padrão para caracterizā-las. como rotina o soro era Inativado a $55^{\circ} \mathrm{C}$ por 30 minutos, com agitação moderada; sendo en seguida misturado ao DME e esterilizado por filtração em filtros Mililpore ou velas de porcelana (filtros Pasteur). 0 soro era normalmente guardado congelado a $-15^{\circ} \mathrm{C}$, passando, eventualmente, por diversas descongelaçöes. Melos prontos (cor ou sem soro), no entanto, nunca eram congelados, permanecendo em geladeira e evitando-se estocar por mais de dols meses.

f. Fracionamento de soro e extração de esteróides Alëm de processos tradicionais para fracionamen to de soro dois tratamentos foram particularmente úteis: 1) passagem por coluna de carboximetilcelulose (CMC) e 2) extração com carvão ativado. o primeiro estã descrito em detalhes em NISHIKAWA, ARMEIIN e SATO (1974) e sumeriamente envolve as seguintes etapas: soro, inativado por calox, è diallsado 
$-29-$

contra âgua (24 horas; duas trocas; aproximadamente 30 volu u mes) até condutividade menor que $0.8 \mathrm{mmoh}$ en segulda $0 \mathrm{pH}$ é ajustado para 6,5 com $\mathrm{HCl} 1 \mathrm{~N}$; O pequeno precipitado que forma nestas condiçōes è eliminado por centrifugação $10.000 \mathrm{xg}$ por $10 \mathrm{minutos}$ (representa menos que 18 da proteina total); o soro resultante è agora passado en coluna de CMC (previamente equilibrada com tampão fosfato de södio $5 \mathrm{mM}, \mathrm{pH}$ $6,5)$; nestas condições 1 a 28 da protelna total è adsorvida e pode ser eluida com o mesmo tampão fosfato mas contendo $\mathrm{NaCl} 0,2 \mathrm{M}$. A fração retida em CMC contēm diversos fatores que promovem o crescimento de células en cultura e para efelto de descrição vamos chamä-la CMC-F. O soro depols de passa do pela coluna torna-se pobre em fatores de crescimento para determinados tipos de célula.

O segundo tratamento, isto é, a extração com carvão, foi desenvolvido para se obter soro isento de esteröis. o protocolo estabelectdo fol: soro (não inativado) era extraido com $10 \mathrm{mg} / \mathrm{ml}$ de Norit A (Sigma Co.) e $1 \mathrm{mg} / \mathrm{ml}$ de Dextran. T40 (Pharmacia) por 30 minutos, a $55^{\circ} \mathrm{C}$ com agita ção vigorosa; as particulas de dextran cobertas de carvão, são em segulda eliminadas por centrifugação e filtração. A eficiência de extração de esterōis foi determinada usando-se diversos hormôntos esteróis radioativos como marcadores; um sumärio dos dados obtidos è apresentado na Tabela I. Como os dados indicam, o nivel de esteröls é reduzido de aproximadamente 100 vezes; tiroxina, no entanto, è ineficlentemente extraida. Evidestemente esta extração não ë especifica para es terōis, multas outras substâncias podem se adsorver ao carvão, certamente ácidos graxos adsorvem-se de maneira eficien te (CHEN, 1967). Este processo, no entanto, mostrou-se mais 
adequado que a extraçäo com solventes orgänicos e cromato grafia em sephadex. Embora o carvão não extraia proteinas (pe Io menos de maneira quantikativamente significante), o soro depois da extraçāo torna-se pobre em alguns fatores de cresci mento, cuja atividade são é reconstituỉa pela aảção de este röis, mas sim pela adição de certos fatores proteicos (con forme será indicado en outras partes desta tese).

g. Contagens de células e medidas de "eficiência de plaqueamento"

Células foram rotineiramente contadas em "Coul ter counter": depois de tripsinizadas, as células eram suspensas em salina fosfato (livre de $\mathrm{Ca}^{2+}$ e $\mathrm{Mg}^{2+}$ ) e contadas no intervalo de 500 a 15.000 cëlulas/ml. As contagens do "Coulter" neste intervalo eram lineares e comparäveis com contagens diretas feitas en hemocitômetro e microscópio. Mediaas de eficiência de plaqueamento (ensaio de frequência de células capazes de formar colónia e que é usado neste trabatho como ensaio de viabilidade) foram feitas de acordo com o seguinte protocolo: células (numa suspensão de células isoladas), eram contadas em hemocitômetro (eventualmente en "Coulter") e plaqueadas ("single cell plating") na concentração de 200 a 400 células por placa (placa de 10 cm de diâmetro); cres cimento era permitido por 7 ou 8 dias e então as placas eram. recolhidas, as colônias fixadas com formol (10\%) e coradas com "crystal violet" $(0,1 q)$; colônias com pelo menos cinquenta cế lulas eram contadas. Nestas experiências o meio CFB dá os maiores niveis de eficiência de plaqueamento, para algumas li Ihagens praticamente $100 \%$ de células desenvolvem colónias.Por esse motivo este meio tem sido usado em nossas experiências 
como meio rico de referência en relação ao qual outros são aferidos.

h. Processos de dissociação de tecidos para cultura primäria

Cëlulas de tecidos podem ser dissociadas por meios fisicos (picagem com tesoura, passagem por malhas de uma rede, etc.) e ou tratamento enzimātico (tripsina, colagenase, hialuronidase, etc.). Em nossa experiência tripsina foi usada na mesma concentração usacia para subcultivos; colagena se dissolvida em solução salina ou em meio de cultura (proteinas de soro "inibem" proteases contaminantes da preparaçāo). Para o caso do tumor mamārio de rato, em foco nesta tese, o tratamento enzimātico revelou-se desaconselhāvel,pois levava a alto rendimento em fibroblastos (critério morfológico). O processo adotado para plaqueamento foi o seguinte : pedaços de tecido umedecidos em meio (CFB) eram picados extensivamente com tesoura e depois suspensos em meio CFB e pas sados diversas vezes por pipeta de ponta fina. Nesse proces so o tecido conectivo (estroma) mais resistente permanecia em pedaços relativamente grandes e o tecido mamärio tinha a tendência a se desmembrar em células isoladas ou grupo com pequeno nümero de cēlulas. Os pedaços relativamente grandes, rapidamente sedimentavam por gravidade eo sobrenadante enri quecido em cēlulas mamárias era recolhido: estas cēlulas eram plaqueadas com densidade moderada para se obter pequenas colô nias aderidas a placa e isoladas umas das outras. 
i. Clonagem

Cêlulas eram clonadas pelo seguinte métodosefetuava-se um plaqueamento a baixa densidade $(50$ a 100 cêlulas por placa de $10 \mathrm{~cm}$ ) a partir de uma suspensāo de células isoladas ("single cell plating"); permitia-se o crescimento de colônias; colôntas que se desenvolviam a partir de uma ünica célula eram então isoladas por tripsinização, com a ajuda de um pequeno cilindro de aço inoxidävel com graxa de silicone de um lado ("cloning ring"), o qual permitia 0 isolamento da colônia das demais colônias presentes na placa. o processo era repetido mais uma vez antes de admitir com rigor que uma população era realmente um clone.

\section{j. Processo de congelamento de células}

Células eram rotineiramente congeladas em CFB com 58 de glicerol (eventualmente $5 \%$ de DMSO). Para tanto, cé lulas eram tripsinizadas imediatamente antes do congelamento, suspensas no meio com glicerol, numa concentração em torno de $10^{6}$ células por ml e colocadas em ampolas (vidro ou plästico) em aliquotas de $1 \mathrm{ml}$. As ampolas seladas eram colocadas em geladeira por 30 minutos e depois no reservatório de nitrogênio líquido, a alturas progressivamente mais pröximas da superficie do nitrogênio (o que propicia congelamento lento), sendo finalmente imersas no líquido. Um outro processo relativamente mais simples envolve a passagem da geladeira diretamente para um congelador de $-70^{\circ} \mathrm{C}$ (Revco), por pelo menos 24 horas e depois imersāo em nitrogênio líquido. O des congelamento era efetuaco simplesmente por retirada das ampo las do nitrogênio e imersão imediata em água a $37^{\circ} \mathrm{C}$ (desconge 
$-33-$

lamento rāpido); após equilíbrio a ampola era aberta e 7 suspensão de células era plaqueada com $10 \mathrm{ml}$ de CFB, sendo o melo trocado 12 a 24 horas depois. Para as linhagens de célu las usadas neste trabalho congelamento e descongelamento eram efetuados mantendo-se viabilidade alta ( 808 ou mais).

\section{Incorporação de timidina- ${ }^{3} H$}

Timidina- ${ }^{3} \mathrm{H}$ era adicionada ao meio em concen trações de $I \times 10^{-8}$ a $1 \times 10^{-6} \mathrm{Me} 0,2$ a $1 \mu \mathrm{C} / \mathrm{ml}$; depois da Incorporaçāo as cēlulas eram tratadas com ācido tricloroacēti co 108 a frlo (três lavagens; este tratamento acarreta ao mes mo tempo fixação e extração dos "pools" solūveis em ācido), dissolvidas em NaOH $0,5 \mathrm{~N}$ ( 12 horas a $\left.37^{\circ} \mathrm{C}\right)$ e precipitadas com

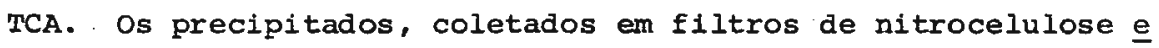
ram contados em cintilador com tolueno-POPOP-PPO.

\section{m. Autorradiografia}

Depols da incorporação do precursor radioativo as cëlulas eram fixadas e os "pools" solūvets eram extraĩdos com TCA 108 a frio (três lavagens, 30 minutos cada); após o tratamento com TCA as placas eram lavadas com etanol 1708 e 958) e secadas ao ar. As placas secas eram cobertas com "stripping film" (Kodak ARlo) e expostas por tempo adequado.

\section{ת. Teste para micoplasma}

Micoplasma è um contaminante comum de células de mamifero em cultura sendo um dos problemas mais sērios que afligen os investigadores neste campo de trabalho. A detecção destes contaminantes exige cultura em meios e condições 
$-34-$

apropriaias, sendo processos tediosos e pouco prāticos como rotina. Felizmente hà um processo eficiente e simples de detecçāo indireta atravēs de autorradiografia após a incorporação de timidina- ${ }^{3}$ H (NARDONE et al, 1965; STUDZINSKI, GIERTHY e CHOLON, 1973). Neste trabalho o processo autorradiográfico foi usado como rotina: as culturas eram submetidas à incorporação de timidina- ${ }^{3}$ H por 12 horas (pulsos tornam dificil a de tecção de pequenas contaminações) e em seguida eram processadas para autorradiografia. Em caso de contaminação o autorra diograma apresenta grãos sobre o citoplasma da célula; se a infecção for pequena os nücleos celulares aparecem normalmente marcados, mas em contaminações acentuadas os nücleos apare cem corn pouca marcação ou nāo são marcadoś, apesar das cēlu las estarem crescendo e se dividindo.

o. Preparaçōes de hormōnios

Preparações impuras de hormônio luteinizante (LH), estimulador do foliculo (FSH), de crescimento (GH), estimulador de tixóide (TSH) e prolactina foram fornecidos gratuitamente pelos U.S. National Institutes of Health (NIAMD, Hormone Distribution Program). Amostras de LH altamente puri ficada foram obtidas do NIH e também como presente do Dr. D. Gospodarowicz (Salk Institute). O fator de crescimento epi dérmico ou epitelial (EGF) foi um presente do laboratörio do Dr. H. Herschman (University of California, Los Angeles).Esta preparaçōes eram dissolviaas em salina fosfato (pH 7,0) a 100 $\mu \mathrm{g} / \mathrm{ml}$ e mantidas congeladas. Insulina de porco cristalina (Sigma Co.) era mantida em soluçāo estoque, salina, pH 3,5 , $100 \mu \mathrm{g} / \mathrm{ml}$, congelada. Hormōnios esterōides puros eram mantidas em solução estogue de etano1958, a $500 \mathrm{\mu g} / \mathrm{ml}$, na geladeira. 
p. Ensaio de lactose sintetase

A lactose sintetase (UDP-galactose; glicose B $1 \rightarrow 4$ galactosiltransferase) è uma transferase de grupos ga lactosídicos, que só se encontra nas cēlulas secretoras das glândulas mamärias, a qual catalisa a seguinte reação: UDP-D-galactose + D-glicose + lactose + UDP Nesta tese esta enzima foi tomada simplesmente como indicado ra da função das células secretoras das glândulas mamărias. Seu ensaio foi efetuado seguindo protocolo de BABAD e HASSID (1966). Como substrato foi usado UDP-D-galactose- ${ }^{14} \mathrm{C}$ (marcado apenas em galactose); a atividade foi seguida pela passagem da mistura de reação em resina aniônica (Bio-Rad Ag, 200 a 400 mesh, forma cloreto, previamente lavada com lactose). Se a reação se processa ${ }^{14} \mathrm{C}$ passa pela coluna na forma de lactose e UDP-gal é retida; a presença de hidrolases que podem levar a liberaçāo de gal- ${ }^{14} \mathrm{C}$ era controlada. Mistura de reação: $20 \mu \mathrm{l}$ de $\mathrm{MnCl}_{2} 0,3 \mathrm{M}, 10 \mu \mathrm{l}$ de D-glicose $0,3 \mathrm{M}, 30 \mu \mathrm{l}$ de UDPgal- ${ }^{14} \mathrm{C} 2 \times 10^{-5} \mathrm{M}(250.000 \mathrm{cpm})$ e $90 \mu 1$ de Tris-HCl $0,0.2 \mathrm{M}$, pH 7,5; após a reação adicionava-se à mistura $850 \mu \mathrm{l}$ de TrisBCl e passava-se por uma coluna de $0,5 \times 1,2 \mathrm{~cm}$; a radioativi dade retida pela coluna era quantitativamente eluida com $2 \mathrm{ml}$ de $\mathrm{HCI} I \mathrm{~N}$.

q. Determinação de cAMP e cGMP

O método usado foi o radioimunoensaio de STEINER, PARKER e RIPNIS (1972). Anticorpos e derivados iodados $\left({ }^{125} I\right)$ foram adquiridos da Collaborative Res. InC.;CAMP, dibutiril CAMP e CGMP foram obtidos da sigma ou Calbiochem; $3^{\prime}, 5^{\prime}$-nucleotidio ciclico fosfodiesterase de coração de bol 
(BUTCHER e SUTHERIAND, 1962) Ioi comprada da Sigma. A fixação das cẻlulas e extração dos nucleotidios foram efetuados com TCA 10\%; TCA foi posteriormente eliminado atravês de extração com ëter; seguia-se, normalmente, liofilização do extrato, o qual era então dissolvido em pequena quantidade de acetato de sódio, $\mathrm{pH} 6,2,0,05 \mathrm{M}$, e guardado congelado a $-15^{\circ} \mathrm{C}$. Nos casos em que os nucleotidios foram purificados, usou-se troca iônica como processo, segundo o protocolo de MURAD, MANGANIELLO e VAUGHAN (1971). Os niveis de nucleotidios foram expressos em termos de picanoles por nümero de cEE Iulas (determinado em placas paralelas) ou proteína total (determinada pelo mētodo de LOWRY et al, 19:51, apōs a extração com TCA) e ou RNA total (determinado pelo mêtodo de FIECK e MUNRO, 1962).

\section{r. Determinação de radıoatividade}

Neste trabalho os compostos marcados radioativamente continham ${ }^{125} \mathrm{I}, 3_{\mathrm{H}}$ ou ${ }^{14} \mathrm{C} .{ }^{125} \mathrm{I}$ foi medido num contador Nuclear Chicago para raios $\gamma \cdot{ }^{3} \mathrm{H}$ e ${ }^{14} \mathrm{C}$ foram determi nados num espectrômetro de cintilação. IIquida. A solução cintiladora normalmente usada foi tolueno-POPOP-PPO; mas em casos em que a amostra estava em soluçāo aquosa usamos a mistura solução tolueno-POPOP-PPO (duas partes) mais triton X100 (uma parte). 
TABELA I

Eficiências de extraçāo de alguns hormônios por carvão ativo

\begin{tabular}{|c|c|c|c|}
\hline \multirow[t]{2}{*}{ Esteröides } & \multirow[t]{2}{*}{$\begin{array}{l}\text { Concentração do } \\
\text { composto radio- } \\
\text { ativo acidiona- } \\
\text { do }(M)\end{array}$} & \multicolumn{2}{|c|}{$\begin{array}{l}\text { ò da radioativi- } \\
\text { dade inicial ex- } \\
\text { traída às tempe- }\end{array}$} \\
\hline & & $4^{\circ} \mathrm{C}$ & $55^{\circ} \mathrm{C}$ \\
\hline Estradiol & $2,5 \times 10^{-8}$ & $90 ; 90^{*}$ & 97 \\
\hline Estradiol & $2,5 \times 10^{-10}$ & & 97 \\
\hline Testosterona & $4 \times 10^{-8}$ & $62 ; 83^{*}$ & 99 \\
\hline Estrona & $2,5 \times 10^{-8}$ & & 99 \\
\hline Progesterona & $2 \times 10^{-8}$ & & 98 \\
\hline Hiarocortisona & $2,3 \times 10^{-8}$ & $30 ; 95^{*}$ & 99 \\
\hline Conjugados $-{ }^{3} \mathrm{H}$ & & & \\
\hline Estradiol-glicuronideo & $3,3 \times 10^{-8}$ & & 98 \\
\hline Testosterona-glicuronideo & $2,5 \times 10^{-8}$ & & 92 \\
\hline Estrona-sulfato & $2,5 \times 10^{-8}$ & & 95 \\
\hline Tiroxina- ${ }^{14} \mathrm{C}$ & $5,5 \times 10^{-6}$ & & 71 \\
\hline Salina + estradiol- ${ }^{3} \mathrm{H}$ & $2,5 \times 10^{-8}$ & 99,8 & 99,8 \\
\hline
\end{tabular}

Protocolo: os compostos radioativos for am adicionados a amostras de soro, as quais foram incubadas a $4^{\circ} \mathrm{C}$ para equilíbrio com 0 "pool" endógeno, por pelo menos 2 horas (15 minutos é suficiente): Amostras de $2 \mathrm{ml}$ de soro foram tomadas, misturadas a 0,2 ml da suspensão de carvão, extraía a temperatura indicada imediatamente filtradas em filtros Millipore de nitrocelulose. o filtrado foi usado para medir radioatividade em mistura tolue no-triton.

* Soro aquecido a $55^{\circ} \mathrm{C}$ por 30 minutos antes da adição do compos to radioativo. As extrações a $4^{\circ} \mathrm{C}$ dão una indicaça da ligaça de alta afinidade do composto radioativo a proteinas carregado ras especificas de esteróides presentes no soro (ver WESTPHAL, 1967 e MILGRAM e BAULIEU, 1969). Os dados da tabela são médias de duas determinaçōes independentes. As absorbânclas do soro a $280 \mathrm{~m} \mu$ antes e depols da extração foram $0,580 \pm 0,005$ e $0,580 \pm$ 0,040 (diluído 100 vezes, diversas extraçöes) respectivamente, 0 que indica não haver extração significante de proteinas. 
IV. ESTABELECIMENTO EM CULTURA DE IINHAGENS CLONADAS DE CELULAS DE UM CARCINOMA MAMARIO DE RATO, DEPENDENTE DE ESTROGENO: INTERESSE PRATICO E PROBLEMAS EXPERIMENTAIS

a. Objetivos; bases do plano experimental

Experiências endocrinológicas clässicas de extirpação de órgãos em animais experimentais, mostraram que o desenvolvimento das glândulas mamärias è dependente de secreçōes da hipófise, ovário e cortex adrenal. Por outro lado a terapia de administração de hormônios a ratos triplamente operados (hipofisectomizados, ovariectomizados e adrenalectomizados), mostraram que os hormónios prolactina, estrógenos e glucocorticoides são necessários para o completo desenvolvimento do tecido mamário (LYONS, LI e JOHNSON, 1958). Além disso neoplasias de mama, tanto no homem como em roedores, são Erequentemente dependentes de hormōnio para crescer; daí a extirpaçāo de glândulas endōcrinas, em mulheres portadoras de câncer mamärio, levar a parada do crescimento ou regressão do tumor. Diversas linhagens de tumores mamärios, dependentes de hormônios e transplantáveis em ratos existem hä algum tempo (FURTH, 1970; IGLESIAS, 1970) e alguns estāo à aisposição de investigadores interessados. Tais tumores representam fon tes convenientes de células, a serem usados como material ini cial para desenvolvimento em cultura de linhagens celulares, cujo crescimento seria dependente de hormônio. A meta final deste projeto era a obtençāo de linhagens, clonadas e estäveis en culturas, as quais desenvolvem "tumores 
dependentes de hormônio" em hospedeiros apropriados. As facilidades metodolögicas da cultura permitiriam o uso de linhagens deste tipo como modelos experimentais de utilldade para estudos de interesse prático imediato, como a terapia do câncer mamärio, ou de interesse bāsico, tanto para a endo crinologia (estudos do mecanismo de ação de hormônios especí ficos) como para a biologia celular geral (estudos dos mecarismos regulatórios de crescimento celular).

Este Capitulo descreve os resultados obtidos no estudo do estabelecimento en cultura de cēlulas mamārias, a partir de tumor dependente de altos niveis de estrógeno em animais com hipöfise, transplantáveI em ratos AxC e desenvolvido por R. IGLESIAS (1970). A abordagem experimental planejada envolvia o uso do processo de "passagens alternadas de células em cultura e em animal", desenvolvido por BUONASSISI, SATO e COHEN (1962) e aplicāvel ao estabelecimen to de linhagens de células diferenciadas em cultura a partir de tumores funcionais. A base racional deste processo é sim ples: i) a norma geral é fibroblastos proliferarem rapidamen te em cultura suplantando outros tipos de cēlulas (que se dí videm lentamente ou não se dividem), eliminando-as; ii) na primeira passagem de um tumor em cultura as cēlulas neoplāsticas são selecionadas para as que melhor subrevivem e proliferam em cultura; estas representam em geral uma parcela pequena da populaçāo; iii) durante o mesmo pẹ ríodo os fibroblastos normais proliferam, mas antes que estes "sufoquem" as células neoplásticas sobreviventes, a cultura é reinoculada no animal hospedeiro; iv) no animal as cee lulas neoplāsticas são favorecidas, pois os fibroblastos, sen do rormais, estão sob o controle endōgeno do crescimento, 
$-40-$

enquanto as células neoplāsticas desenvolvem um novo tumor; - qual está agora enriqueçido nas células neoplásticas que melhor sobrevivem nas condições de cultura; v) civersas pas sagens cultura-animal podem ser feitas para efetuar seleção progressiva e na etapa final as células neoplásticas seleclonadas tem que ser clonadas; finalizando-se assim o proces so de isolamento e estabelecimento das células en cultura.t importante lembrax que uma vez isoladas e clonadas as cêlulas precisam ter a sua identidade provada bioquimicamente a travēs da expressão, en cultura, de uma função bioguImica especifica do tecido de origem; a morfologia e estrutura em cultura è um critērio pobre de identificação, embora, as ve zes, seja o único disponível.

No caso do tumor mamärio em estudo as cultu ras primärias eran fettas em meio CrB suplementado como os hormônios: prolactina, insulina, hidrocortisona, progestero na e estradiol (desde que pretendia-se favorecer o cresci mento de cēlulas dependentes de hormônio). As culturas prí märias eram inoculadas em animais machos normals e machos com implante de pastilhas de estradiol, para testar o eventual aparecimento de tumores autônomos, um evento relativamente comum nestes tipos de tumores. Como meios minimos (meios carentes nos hormônios estimulantes) foram adotados meios preparados com soro de cachorro ou rato hipofisectomi zaco ou com soro de vitelo extraldo com carvão ativo (ver Métodos). As culturas erara examinadas diariamente ao microscöpio de fase, usando-se critērio morfológico como guia de rotina: classificando-se as cêlulas como epiteliais (pro váveis células mamārias) e fibroblásticas; o critērio bioquímico adotado para identificação das cëlulas foi 
$-41-$

a procura de atividade de lactose sintetase, uma enzima expecifica das cēlulas acinosas do tecido manärio. f importan te lembrar que o ponto indeterminado do protocolo adotado $\bar{e}$ - nivel dos hormôntos adicionados ao meio das culturas primárias; è provável que o crescimento das cēlulas dependa de concentrações e combinações crîticas dos hormônios, esta ques tão, entretanto, não tinha soluçāo "a priori", devendo ser enfrentada empiricamente por tentativa e erro.

b. Resultados

1. Seleção por passagens alternadas em cultura e animal

Culturas primárias, mantidas por até 25 dias, quando injetadas em animais ( 1 a $2 \times 10^{7}$ células por animal) deram "tumores dependentes de hormônio", cujo crescimento foi imediato, conforme as curvas da Figura $4 a$ e b indicam. Nestas culturas o fato mais relevante foi a necessäria presença de células epiteliais tỉpicas para se observarem os tumores dependentes em animais. Uma observação nāo antecipada fol o aparecimento de tumores de desenvolvimento tardio (FIgura 4a: 7 a 8 meses; $4 b: 3$ a 4 meses) em animais controle. Estes tumores autônomos eram transplantáveis, desenvolvendo-se sem pe ríodo de latência mesmo em animais hipofisectomizados, confor me a Figura $4 f$ e g mostram. Eram tumores esbranquiçados, solidos, duros e fibrosos; histologicamente (cortes corados com hematoxilina e eosina) mostraram tecido fibroso, claramente distinto do adenocarcinoma de tumor orlginal; a explicação adotada foi que se tratava de un fibrosarcoma oriundo da 
$-42-$

transformação de fibroblastos normais, a qual ocorreu provavel mente em cultura. Tal evento é de ocorrência conhecida e até provāvel, levando em conta que nas culturas primärias fibro blastos foram mantidos crescendo em alta densidade (ver AARONSON E TODARO, 1968 e SANFORD, 1968). Embora o aparecimento do fibrosarcoma tenha tornado o mētodo de passagens alternadas cultura-animal ineficiente, o tumor dependente pode ser mantido estável através de transplantes sucessivos animal-ani mal (ver Figura 4c, d e e), mesmo depois da terceira passa gem em cultura. Após a quarta passagern em cultura o tumor autônomo mostrou menor período de latēncia e maior velocidade de crescimento (Figura $5 \mathrm{a}$ e b). Na quarta passagem em cultura foi testado se BUDR adicionado ao meio de cultura pri mária influenciaria a capacidade tumorogênica das células (fa to relatado por SIIAGI, 1971, para melanonas): conforme a Figura $5 a$ e b indicam nenhum efeito foi observado.

\section{Seleção de células epiteliais en cultura}

As células epiteliais presentes nas culturas pri márias eram, provavelmente, as células mamárias. Era de se esperar que tais células não crescessem nos meios deficientes em hormōnio (soro de animal hipofisectomizado ou soro ex traido com carvão); portanto era razoāvel tentar a seleção des tas células epiteliais em meios deficientes, através de agentes COMO FUDR (POLLACK, TODARO E GREEN, 1968) Ou BUDR (PUCK e KAO, 1967) que matam especificamente cëlulas que sintetizam DNA. Entretanto, diversas tentativas por este processo levaram, invariavelmente, a seleção de fibroblastos. A explicação para este insucesso parece ser dupla: primeiro fibroblastos tem sua replicaçāo diminuỉa em soro hipofisectomizado ou extrāido com 
$-43-$

carvão (ARMELIN, 1973) e segundo cēlulas cancerosas na ausēncia de "reguladores" não entram en repouso ("estado R"), mesno que a população não cresça (ver secçōes seguintes). Em vista disso a seleçăo das células epiteliajs en cultura de via seguir outro processo.

Foi possivel notar que em presença da solução de tripsina, normalmente usada para subcultivo, fibroblastos se descolavam da placa mais rapidamente (5 a 10 minutos) que as células epiteliais (10 a 20 minutos). Esta velocidade di ferencial de descolamento foi usada para enriquecer a população em cēlulas epiteliais; posteriormente colônias encontradas (inspeção microscópica) "puxas" em cëlulas epiteliais eram isoladas e as populaçöes oriundas do cultivo destas cēlulas eram submetidas a clonagem.

Culturas prinárias do 38 ciclo de passagem por cultura foram tratadas com tripsina e deram populações altamente enriquecidas em células epiteliais. Estas culturas selecionadas, mostraram-se altamente "responsivas" a prolactina (impura) para crescer em meio com soro de cachorro-hipofi sectomizado, conforme a Figura 6 indica. Entretanto, não foi possivel clonar estas células e culturas clonadas e estáveis nunca foram obtidas.

No 48 ciclo de passagem do tumor em cultura, as culturas primärias obtidas resultaram,pelo método de tripsina,em excelentes culturas de células epiteliais, as quais foram clonáveis, àariōo culturas cionadas e estáveis indefinida mente. 
3. Comportamento das linhagens clonadas: efeito de hiarocortisona

o crescimento das cēlulas clonadas em meio com soro extraído com carvão (Figura 7, Tabelas II e III) e com soro de animal hipofisectomizado ê altamente dependente da adição de esterōis a cultura. o requerimento é específico para glucocorticoides (hidrocortisona), os quais são ativos em concentrações perfeitamente fisiológicas conforme as curvas de dose da Figura 8 indicam. Os hormônios proteicos insulina e prolactina não tiveram efeitos significantes seja no crescimento (Tabelas III e IV) seja na eficiência de plaqueamento (Tabela III) destas células. O soro, entretanto, contẻm fatores absolutamente necessários a sobrevivência das cëlulas, fatores esses que não podem ser substituíos por hor mônio; conforme a Tabela II indica $2 z$ de soro de vitelo mesmo com hidrocortisona dá eficiência de plaqueamento essencialmente nula. A população das células clonadas em meio com soro extraído com carvão pode ter crescimento nulo, enquanto a adição de hidrocortisona ao mesmo meio dá crescimento rápi do, como a Figura $7 b$ indica. Apesar do crescimento nulo da população as células não entram em repouso ("estado $R^{\text {") }}$, conforme a alta incorporação de ${ }^{3} \mathrm{H}$-timidina en DNA mostra(Fí gura $7 b)$. O crescimento lento ou nulo da população è éevido a morte de células, conforme è mostrado diretamente pelas me didas de eficiência de plaqueamento (Tabelas II e III); notar que fibroblastos ( $3 \mathrm{~T} 3$ ) também crescem pouco em soro extraído (ARMELIN, 1973), mas a eficiência de plaqueamento não é afetada (ver Tabela II). Estes resultados mostram que hidrocortisona tem, operacionalmente, dupla função: è fator de "sobrevivência" (meio 108 VC; eficiência de plaquearnento) e é fator de 
"crescimento" (acelera crescimento em $108 \mathrm{~V}$, onde EP ë alto).

As linhagens de cēlulas clonadas foram testadas para a atividade de lactose sintetase, seja na presença ou na ausència de prolactina e en diversos meios, os resultados foram sistematicamente negativos. Para a sërie de clones estudada o nümero médio de cromossomos por célula foi 69 . As mesmas cêlulas quando inoculadas em animais $\left(10^{7}\right.$ células animal), desenvolvem tumores em animais normais, machos ou fê meas, mas tem a tendência a não dar tumores em animais hipofisectomizados e adrenalectomizados (tempo de observação limi tado pela curta sobrevivência dos animais operados, em torno de 1 mês).

4. AMP e GMP cíclicos: efeitos da adição ao meio de cultura e niveis intracelulares

A adição de dibutiril cAMP ao meio de cultura antagoniza a ação estimulatória de hidrocortisona e esta ação antagonizante è potenciada pela adição conjunta de teofilina (um inibidor de fosfodiesterase), conforme a figura 9 mostra; - efeito do nucleotídio cíclico e ou teofilina é aumentar a incidência de morte e não o bloqueio do crescimento e divisão celular. Os niveis intracelulares de cAMP e cGMP foram medidos para células em 108 vc com ou sem hidrocortisona (Tabela v); na presença do hormônio o nível de cAMP è baixo (o que concorda com a regra para cêlulas cancerosas), mas na sua ausência os niveis podem ser altissimos; CGMP não varia signifi cantemente. Evidentemente, estas correlaçōes não mostram que os altos niveis de cAMP sejam a causa da morte da célula, mas são sugestivas; assim como os resultados não implicam que $\circ$ 
decrēscimo do nivel de cAMP seja necessariamente consequência direta da ação de hidrocortisona.

A adição de cGMP ao meio com 108 VC provocou um incipiente aumento da população, efeito cuja significância ë dificil de considerar, mas se comparado ao efeito da hidrocortisona fica sem dūvida negligenciăvel (Tabela vI).

\section{c. Conclusōes}

1. O estudo descr1to aqui dá uma dimensão das li mitaçöes do processo de estabelecimento de linhagens de cëlulas en cultura, dado o empirismo ao qual esta tarefa estā sujeita. Uma tentativa de esgotar as possibilidades racionais de ataque do problema fol feita; os resultados mostra ram que i) o processo de passagens alternadas de cêlulas da cultura para o animal, de BUONASISSI e colegas, embora aparentemente ïtil, tem limitaçōes sērias e ii) os processos de seleção com agentes como BUDR e FUDR, dependem de conse guir que as células desejadas entrem em repouso e è possị vel que cēlulas cancerosas nāo entrem em repouso quando pri vadas de reguladores. O processo de seleção com tripsina uma observação que não podia ser artecipada, acabou forne cendo elementos experimentais para seleção de células epite liais. Embora este processo tenha sido interessante nada diz "a priori" qual a sua utilidade em outros casos.

2. Dentre as implicações co estudo do comportamento dos clones, um dos mais interessantes è que a dificuldade encontrada em conseguir que estas células entrem em repouso ("estado $R$ "), talvez venha do fato de que células 


$$
-47-
$$

neoplästicas nāo entram en repouso quando privadas de "regula dores" do crescimento. $E$ interessante comparar estes resultados e esta sugestão com o que descrevemos para fibrobiastos transformados por virus, no Capitulo seguinte lo mesmo problema è abordado com um pouco mais de minucia em ARMELIN, 1974).

3. Parece válido concluir que este estudo mostra que é possivel desenvolver clones estabelecidos em cultura,a partir de tumores dependentes de hormōnio em animal. Clo nes deste tipo prometem ser úteis para o estudo de mecanis mos hormonais e suas implicaçōes nas neoplasias. 
$-48-$

TABELAS E FIGURAS 


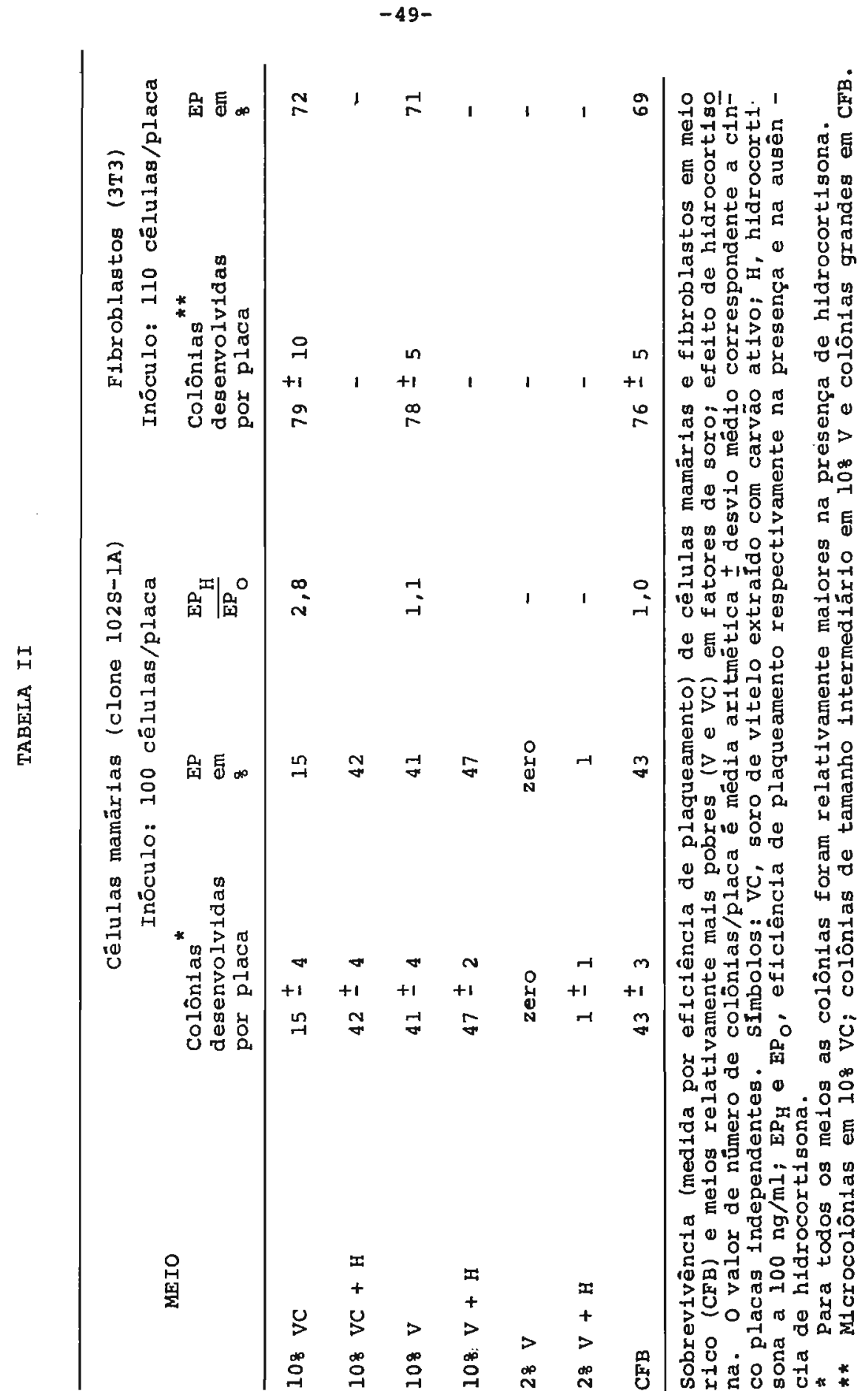




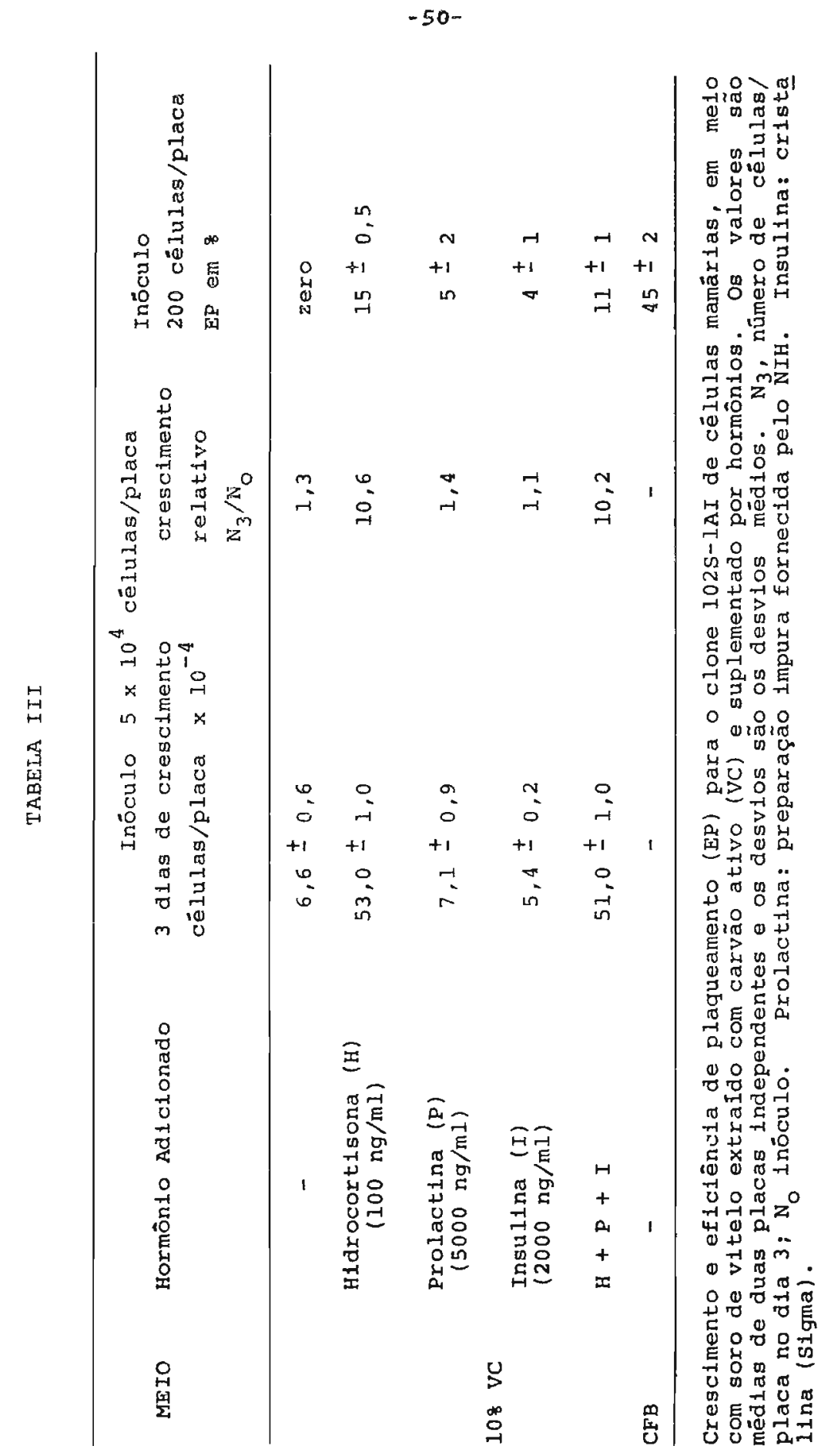




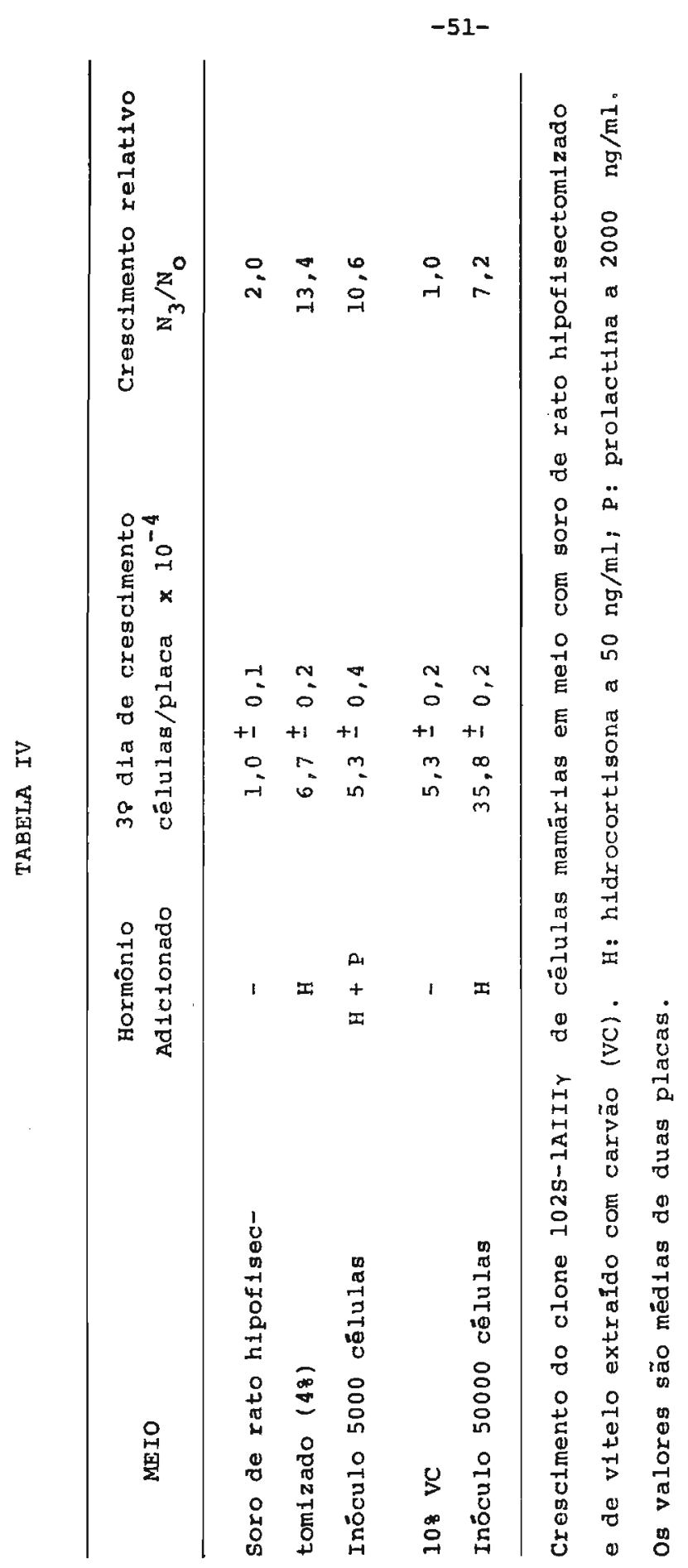


TABELA V

\begin{tabular}{|c|c|c|}
\hline \multirow[t]{2}{*}{ MEIO } & Niveis intr & em pmoles/mg \\
\hline & CAMP & CGMP \\
\hline $10 \% \mathrm{VC}$ & $17,0-100$ & $0,22 \pm 0,06$ \\
\hline $\begin{array}{c}108 \mathrm{VC}+\mathrm{hidrocortisona} \\
50 \mathrm{ng} / \mathrm{ml}\end{array}$ & $9,0 \pm 0,2$ & $0,20 \pm 0,01$ \\
\hline
\end{tabular}

Niveis intracelulares dos nucleotídios ciclicos no clone $102 \mathrm{~S}$ IA de cëlulas mamárias, em meio com soro de vitelo extraído com carvão ativo, 24 horas depois do plaqueamento. Culturas esparsas: $10^{4} / \mathrm{cëlulas} 1 \mathrm{~cm}^{2}$. Protelnas 1350-1600 $\mathrm{\mu g}$ e RNA 33-40 $\mu$ g por $10^{6} /$ células em presença de hidrocortisona; Proteỉnas 1600-1800 $\mu \mathrm{g}$ e RNA 46-47 $\mu \mathrm{g}$ por $10^{6} / \mathrm{células} \mathrm{na} \mathrm{au-}$ sência do hormônio. O meio foi retirado das placas por suc ção, as células foram lavađas por suç̧ão com salina fosfato e TCA 10\%, frio foi adicionado imediatamente (a lavagem e adi ção de TCA tomou 30 segundos por placa). As placas com TCA foram incubadas a $2^{\circ} \mathrm{C}$, por 30 minutos; em seguida o TCA foi recolhido e nova extração com TCA foi feita, sendo as duas extrações combinadas. Proteina e RNA foram determinados após a extração com äcido nas cêlulas fixadas que permaneceram a deridas a placa. 
$-53-$

TABELA VI

\begin{tabular}{lcc}
$\begin{array}{c}\text { Meio } 10 \% \mathrm{VC} \\
\text { Suplementado com: }\end{array}$ & $\begin{array}{c}\text { Células/placa } \times 10^{-4} \\
\text { (Inöculo } 10^{4} \text { células) } \\
\text { - }\end{array}$ & $\begin{array}{c}\text { horas } \\
96 \text { horas }\end{array}$ \\
\hline Hidrocortisona $50 \mathrm{ng} / \mathrm{ml}$ & 15 & 16 \\
CGMP $10^{-5} \mathrm{M}$ & 42 & 88 \\
CGMP $10^{-4} \mathrm{M}$ & 24 & 20 \\
CGMP $10^{-3} \mathrm{M}$ & 30 & 24 \\
\hline Efeito da adição de cGMP sobre o crescimento do clone & $102 \mathrm{~S}$ \\
IA de células mamárias. & 26 & 20 \\
meio no momento do plaqueamento nas concentrações indicadas.
\end{tabular}


FIGURA 4 - Crescimento de tumores em animais inoculados com cêlulas "passadas" em cultura. As cēlulas foram inocula das sob a pele e na altura da cintura escapular do animal à direita; as pastilhas de estradiol foram implantadas tambèm sob a pele mas na altura da cintura pélvica. o desenvolvimento dos tumores foram seguidos por apalpação do animal semanalmente; o tamanho do tumor era estimado medindo-se dois diâmetros do tumor (por apalpação) em centime tros; tumores transplantados ou de animais que morriam eram dissecados e pesados. Tamanhos de tumor lançados em unida des arbiträrias, mas tamanho 4 corresponde a um tumor pesan do de 40 a $50 \mathrm{~g} . \square-\square$ animal macho com estradiol; $0-0$ macho normali $\triangle \Delta$ hipofisectomisado; $M$ significa animal que morren naturalmente; $C$ animal sacrificado tumor colocado em cultura; T animal sacrificado tumor transplantado para outro hospedeiro.

FIGURA 4a: células inoculadas depois dá segunda passagem em cultura (15 dias); 4b: cēlulas inoculadas após a $3{ }^{\circ}$ passa gem em cultura ( 25 dias); $4 c$, d e e: são uma sërie de très transplantes seguidos de um dos tumores dependentes de estradiol, cujo crescimento estă indicado em $4 \mathrm{~b} ; 4 \mathrm{f}$ e $4 \mathrm{~g}$ uma série de dois transplantes seguidos do tumor independente in aicado em $4 \mathrm{~b}$. 


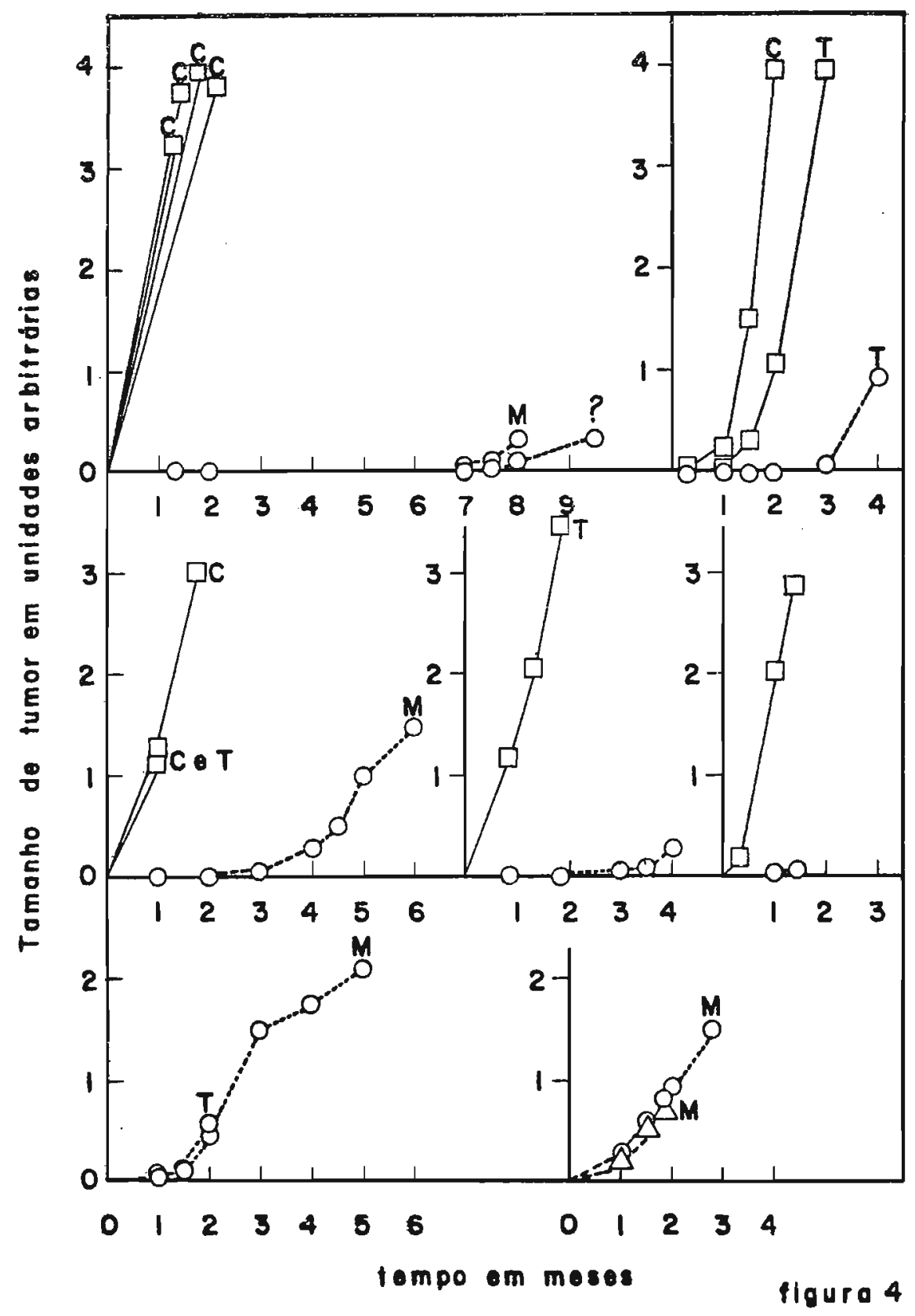


$-56-$

FIGURA 5 - Crescimento de tumores em animais após a guarta passagem em cultura. 5a: cêlulas inoculadas apōs 6 dias em cultura; 5b: o mesmo que 5a, apenas que dois dias antes da inoculação as cêlulas foram mantidas em meio contenđo $30 \mathrm{\mu g} / \mathrm{ml}$ de BUDR e no escuro; o crescimento em cultura não foi afetado por BUDR. Demais informações na Figura 4. 
$-57-$

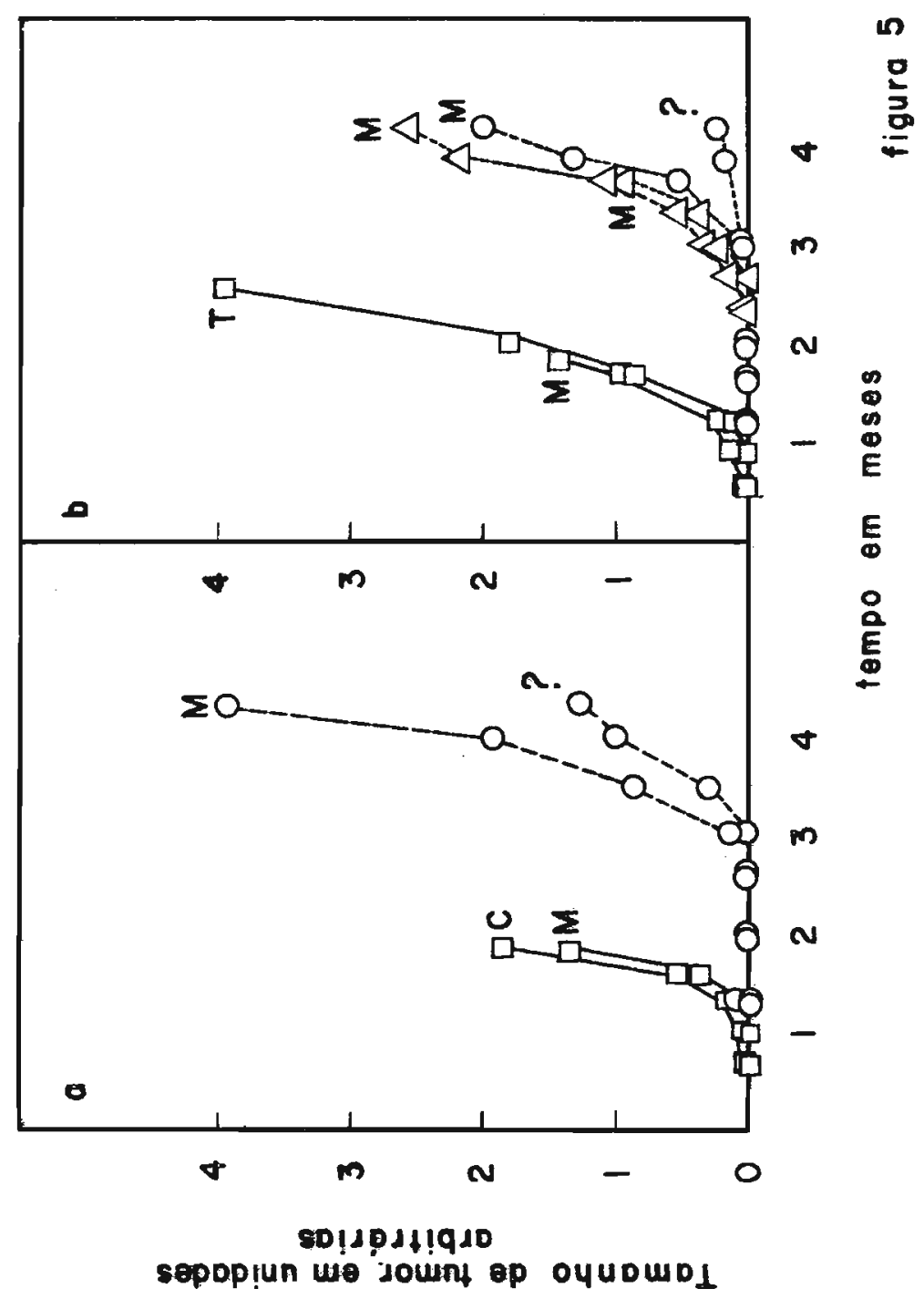


$-58-$

FIGURA 6 - Crescimento de cēlulas epiteliais não clonadas em meio com 108 de soro de cachorro hipofisectomizado. Cé lulas epiteliais nāo clonadas ( $89 \mathrm{~s}$ ), selecionadas pelo mé todo da tripsina três dias antes, foram tripsinadas e pla queadas em meio com 108 de soro hipofisectomizado suplementado com $5000 \mathrm{ng} / \mathrm{ml}$ de prolactina impura (ovina, Sigma) - - i suplementado com $5000 \mathrm{ng} / \mathrm{ml}$ prolactina, $1000 \mathrm{ng} /$ $\mathrm{ml}$ insulina e $1000 \mathrm{ng} / \mathrm{ml}$ estradiol 0--0; e sem suplementaçäo nenhuma $\Delta--\Delta$ (neste caso contagens significantes sô foram obtidas nos dias 9 e 11 ). 


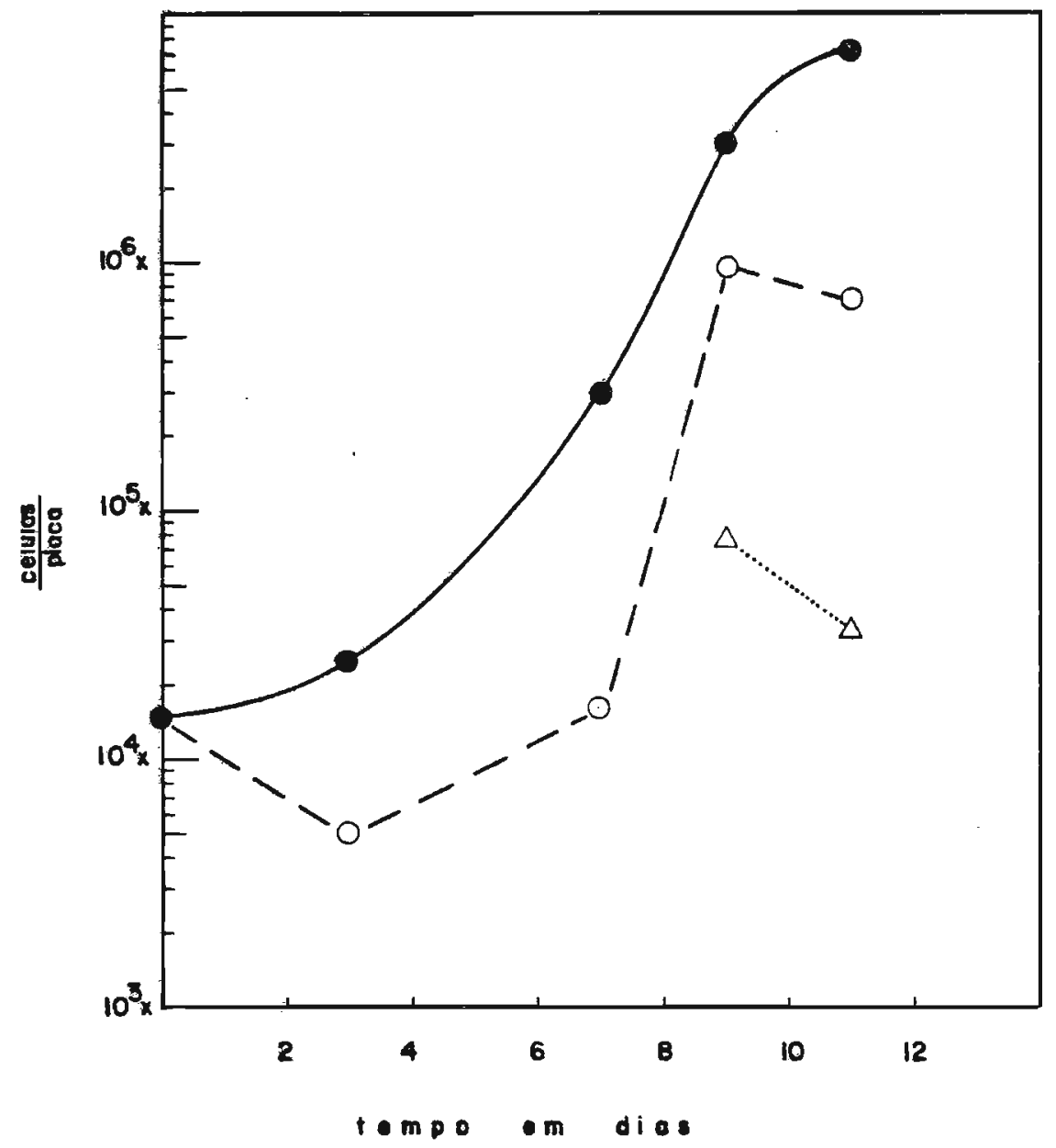

flgura 6 
$-60-$

FIGURA 7 - Crescimento de células clonadas em meio com $10 \%$ de soro de vitelo extraído com carvão. 7a: células do clone 102S-1AIII foram plaqueadas em meio com 108 vC suplementado com $100 \mathrm{ng} / \mathrm{ml}$ hidrocortisona, $100 \mathrm{ng} / \mathrm{ml} \mathrm{proges-}$ terona e $100 \mathrm{ng} / \mathrm{ml}$ estradiol $\longrightarrow$ ou em melo $10 \%$ vC sem suplementação $0 \longrightarrow 0$. $7 \mathrm{~b}:$ clone $1025-1 \mathrm{~A}$ plaqueado em meio 108 VC mais $50 \mathrm{ng} / \mathrm{ml}$ hidrocortisona $\mathrm{DC}$ e em 108 VC não suplementado $0-0$. As atividades especificas indica das no gräfico referem-se a incorporações de ${ }^{3} \mathrm{H}$-timidina $\left(10^{-5} \mathrm{M}, 1 \mu \mathrm{C} / \mathrm{ml}\right)$ por 12 horas entre os dias 2 e 3 . 


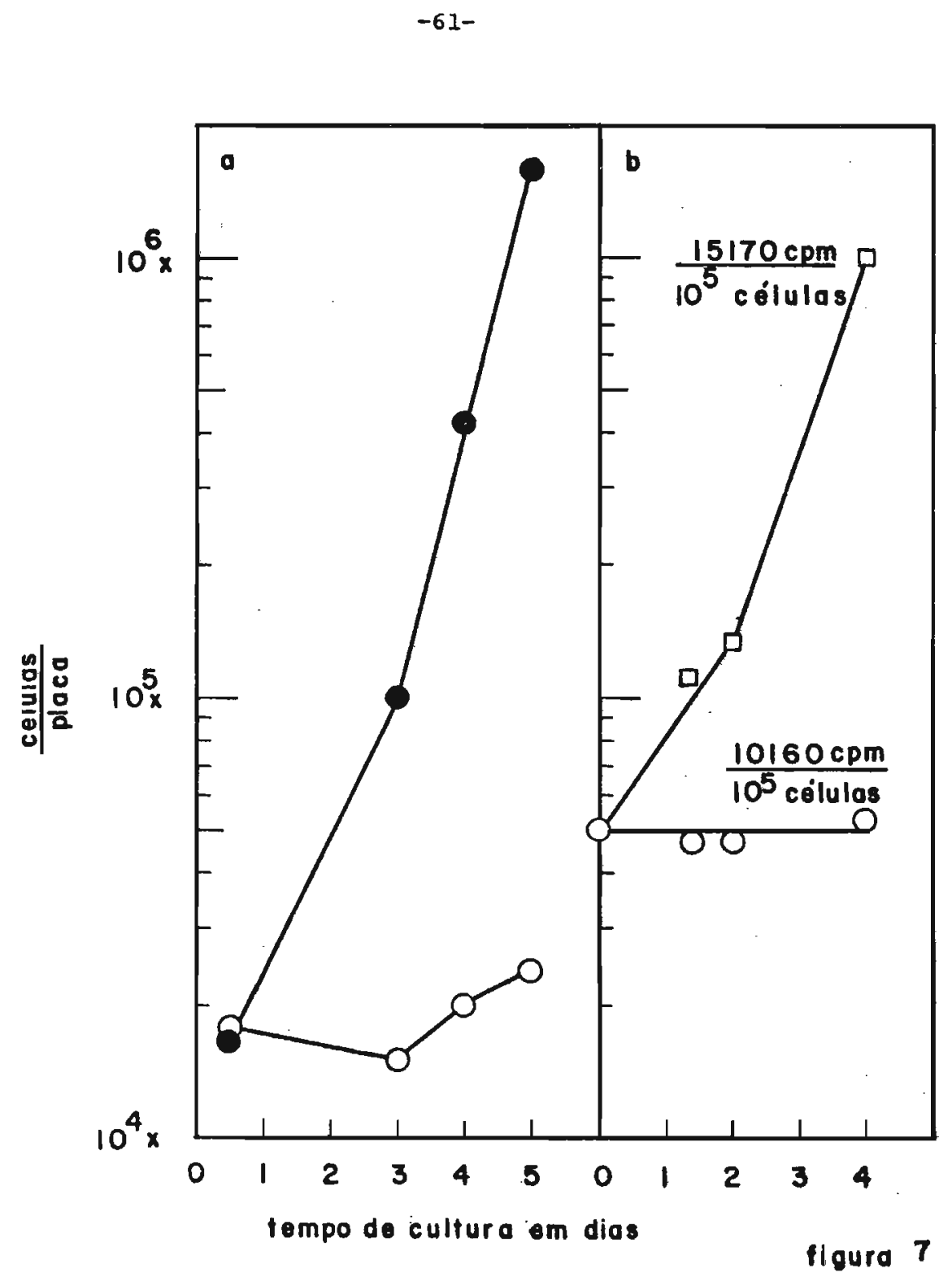


FIGURA 8 - Efeito de diferentes esteröides sobre o crescimento de células clonadas em meio com 108 de soro de viteIo extraido com carvão; curvas de dose. Células do clone 1025-1A foram plaqueadas em meio 108 VC suplementado com um dos esteröides indicados no gräfico; depois de cinco dias de incubação as cēlulas for am contadas e valores de células por placa foram lançados contra a concentração de hormônios em $\mathrm{ng} / \mathrm{mI}$. 


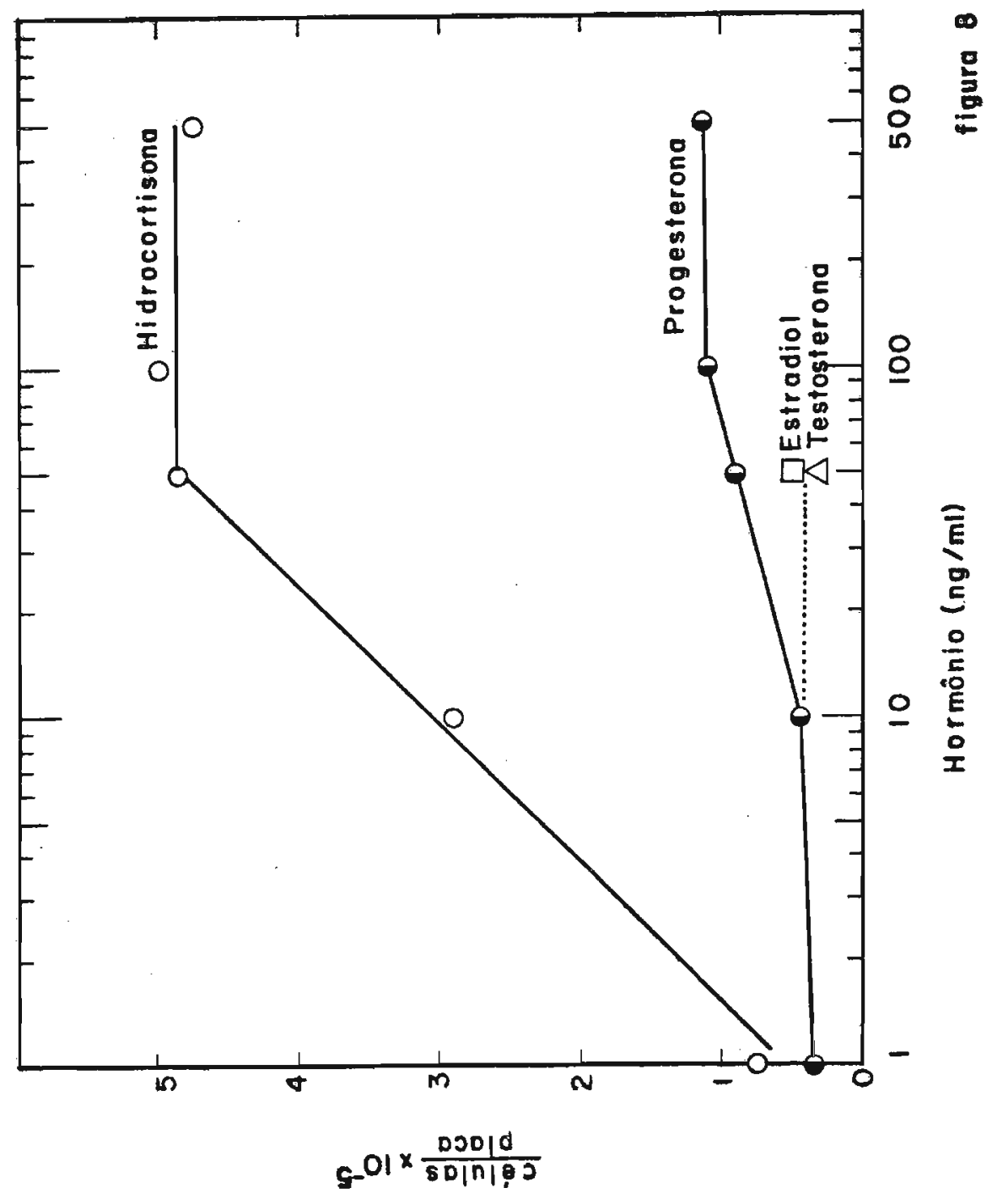


$-64-$

FIGURA 9 - Efeito de hidrocortisona, dibutiril-cAMP e teofilina no crescimento de células clonadas. Células do clone 102S-1A foram plaqueadas em melo 108 VC suplementa dos conforme 1ndicado nos gräficos. H: $50 \mathrm{ng} / \mathrm{ml}$ de hidro cortisona; Di: dibutiril CAMP $10^{-3} \mathrm{M} ; \mathrm{T}^{-3}$ e $\mathrm{T}^{-4}$ : teofilina a $10^{-3}$ e $10^{-4} \mathrm{M}$, respectivamente. 


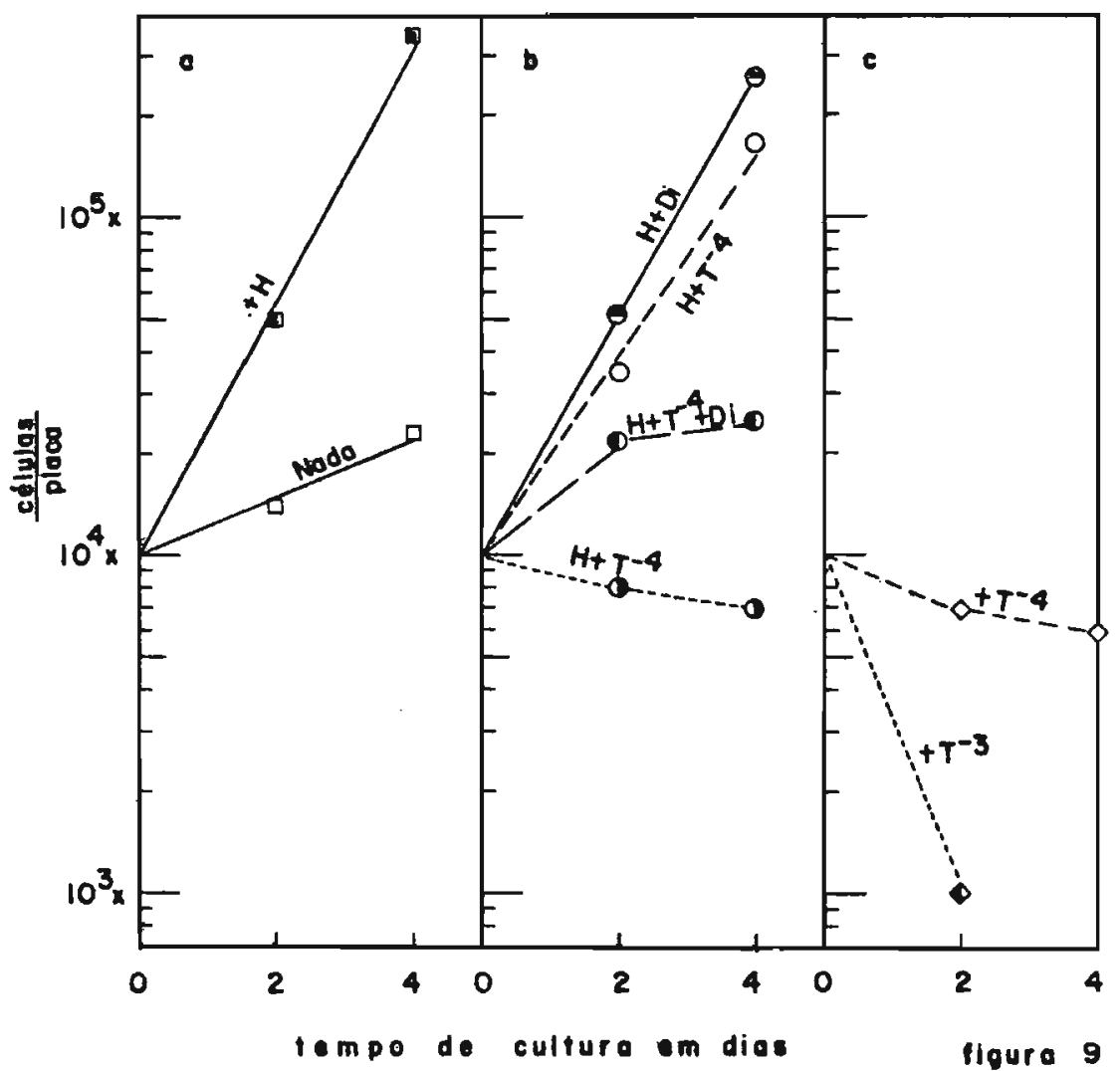


V. CONTROLE DO CRESCIMENTO E DIVISAO CELULAR EM LI NHAGENS DE FIBROBLASTOS MANTIDOS EM CULTURA

\section{a. Histōrico}

\section{Fibroblastos $3 \mathrm{~T} 3$}

TODARO E GREEN (1963) estabeleceram em cultura por um protocolo empirico e sistemätico, a linhagem de fibro blastos 3T3, proveniente de embriōes de canundongos suiços. 0 nome 3 Tr3 originou-se do protocolo: inóculo de $\underline{3} \times 10^{5}$ células transferidos a cada $\underline{3}$ dias. Estas células crescer em monocama das e em meio contendo $10 \%$ de soro de vitelo o crescimento pára quando a camada de células se torna confluente e as células entram em "repouso" parando o "ciclo celular" no inicio de Gl (TODARO, LAZAR e GREEN, 1965). Este fenômeno foi chamado "ini biçāo de contato", nome por sinal cunhado antes do desenvolvimento da linhagem de cêlulas 3т3 (na verdade este nome foi ini cialmente usado no sentido de "inibição de movimento por conta to" e não "inibição de crescimento", ABERCROMBIE e HEAYSMAN, 1954), e implicando que o contato entre as células de alguma maneira levava a inibição do crescimento. E importante ressaltar que já nesta época tinha se observado que células cance rosas não apresentavam "inibição de contato" em cultura. Posteriormente, AARONSON e TODARO (1968) desenvolveram novas linhagens de 3 T3 mas a partir de embriões de camundongos Balb/c. Sendo estes animais de una linhagem geneticamente pura, foi possivel testar a capacidade tumorogênica das linhagens de fibroblastos, verificando-se que as linhagens com "inibi ção de contato" (Balb/c 3T3) não desenvolvem tumores em 
animais. Enquanto isso linhagens sem "inibição de contato", por exemplo Balb/C 6T6, causam tumores quando injetados nos animais. Estas verificações experimentais sugeriram que a "inibição de contato" é uma manifestação em cultura do controle normal do crescimento e as células que 0 exibem são normais. Convem lembrar, no entanto, que 3т3 não é uma cēlu la normal pois tem um cariötipc, aberrante, é quase tetraploi de contendo cromossomos anormais. Não obstante 3 T3 passou a ser um modelo celular dos mais estudados como exemplo do fi broblasto "normal".

2. "Inibição de contato" e fatores do soro

Praticamente todo o esforço experimental devotado nos últimos 15 anos ao estudo do controle do crescimento celular, estava de alguma maneira comprometido com a tentativa de compreensão do fenômeno de "inibição de contato". Antes de levar em conta o fenômeno em si é bom lembrar que um dos seus aspectos è altamente persuasivo, trata-se do observado na experiência de ferimento e cicatrização ("woundhealing") em cultura (DULBECCO, 1970). Nesta experiência uma monocamada confluente de cēlulas "inibida por contato" è ferida, isto è, uma faixa de cêluías de aproximadamente $1 \mathrm{~mm}$ de largura è raspada, rompendo assim a camada continua de célula; nesta operaçâo o meio de.cultura não é mudado. Seguese a isso um fenômeno fascinante: as cëlulas do boráo do "corte" feito na monocamada começam a se dividir atē que a monocamada seja refeita (cicatrização); entretanto, nas partes intatas da monocamada nenhuma célula entra em divisão.Não obstante o interesse gerado em torno da "inibição de contato", 
- seu estudo deu regularmente resultados muito decepcionantes. En 1968 HOLLEY e KIERNAN mostraram que células 3T3 podem conti nuar a crescer depois de confluentes, formando multicamadas em pilhadas se a concentraçāo do soro for aumentada alëm de $10 \%$; eles mostraram, na verdade, que o tamanho da populaçāo quando - crescimento estaciona è função da concentração do soro no meio. Estas observaçōes mostram: primeiro que o contato por si mesmo não leva a nenhuma inibição; segundo que o fato reprọ dutivel de que as células paravam de crescer quando chegavam ã confluência era consequência fortuita do häbito de cultivä-las sempre em 108 de soro; e terceiro sugere que o crescimento ẽ funçāo da concentraçāo de algum fator presente no soro. A outra contribuição a mostrar quāo enganoso è o "conceito de inibição de contato" veio de CECCARINI e EAGLE (1971a; 1971b): es tes autores mostraram que o tamanho da populaçäo, quando 0 crescimento estaciona, è tambēm função do pH do meio; em pH apropriado as células "normais" ficam superconfluentes mesmo em 108 de soro. Em face desses desenvolvimentos experimentais a hipótese que parecia mais ūtil è a que propōe estarem as células "normais", em cultura, sob estrito controle de fatores do soro. Para testar esta hipōtese, a purificação e isolamento dos fatores postulados tornou-se absolutamente necessärio. Embora algum progresso tenha sido feito(JANCHILL e TODARO,1970; PAUL et $a 1,1971$; LIPTON et al, 1971), de maneira geral esta tarefa foi, atē o momento, totalmente insuperāvel, dadas as dificuldades práticas da anāilse bioquỉmica do soro (HOLLEY e RIERNAN, 1971). A consequência disto fol que os fatores de crescimento do soro continuaram como enti dades de existência duviōosa e a função do soro no crescimento das células em cultura continuou nebulosa. 
Um fato importante que contribuiu para aumentar a atração de 3T3 como modelo experimental, foi a possibilida de de transformação destas cēlulas pelo pequeno vĩus de DNA SV40 ("simian virus 40") ; ver SAMBROOK, 1972. 3T3 "normal" quando transformada por SV40 em cultura passa a exibir o comportamento de uma célula cancerosa; em outras palavras, de al guma maneira o controle do crescimento è subvertido (TODARO e GREEN, 1964; TODARO, GREEN e GOLDBERG, 1964). A transformação envolve a integração do genoma do vírus no genoma da cēlu la e o fenótipo da célula transformada depende da expressão de algumas "early messages" do virus integrado(SAMBROOK,SHARP e KELLER, 1972). Dado que o virus tem genoma muito pequeno $\left(3,4 \times 10^{6}\right.$ daltons de DNA), suficiente para codificar apenas 7 ou 8 proteinas de tamanho médio, supunha-se que ele pode ria ser uma ferramenta "simples" e eficiente para explorar as funções celulares ao nível molecular (DULBECCO, 1971).Esta, sem dúviáa, parecia uma alternativa inteligente à opção custo sa da análise bioquimica de sistemas tão complexos como o soro ou a célula. Entretanto, esta esperança parece, a luz dos resultados atuais, que foi excessivamente otimista, não obstante continua como abordagem vălida e promissora, apenas não tāo auto suficiente como se pensava de início.

4. Proteases e controle da divisão celular M. BURGER (1971) observou que se células 3T3 "normais", confluentes e em repouso eram tratadas por um perío do breve com tripsina, a baixas concentraçōes, seu crescimento era iniciado e a duplicaçāo da população ocorria depois de um 
$-70-$

periodo definido de tempo. O efeito imediato do tratamento triptico é tornar as cêlulas aglutinäveis pela aglutinina do germe de trigo (ou, tambēm, por concanavalina A), propriedade não exibida pela cëlula "normal" em repouso, mas sempre exibida pela célula transformada. Baseado nestas observa Çöes BURGER propos que proteases digerem proteinas que, nas cêlulas em repouso, "cobrem" receptores (indicado pelo efeito da aglutinina ou da concanavalina A) expondo-os; tais receptores uma vez expostos podem entrar em contato com fatores do meio e desta maneira o crescimento e divisão celulares são desencadeados. As células transformadas teriam seus recepto res permanentemente expostos dai o crescimento "descontrolado"; por outro lado quando as cêlulas chegam a confluēncia os receptores säo recobertos. Esta teoria e seu autor gozaram por algum tempo de grande popularidade, entretanto, parece, agora, tratar-se de hipötese completamente errada. Primeiro, diversos iaboratōrios tem sido incapazes de repetir os resultados de BURGER, isto é, desencadear crescimento em 3 T3 3 com tripsina CCONNINGHAM e TRASH, 1974; HOLLEY e KIERNAN, 1974; ARMEIIN, resultados nāo publicados); apesar do tratamento trīptico tornar $3 T 3$ "normal" e em repouso aglutinăvel pela aglutinina ou por concanavalina A como nas experiēncias de BURGER. Segundo, a quantificação dos receptores para concanavalina A mostrou que o seu nümero näo varia ccm o tratamen to proteolitico, fato que deveria ser esperado se os recepto res fossem expostos pela ação da protease. Ao que tudo indi ca os receptores apenas se rearranjarn formando aglomerados em consequēncia da açào da tripsina (NICOLSON, 1971; 1973). 0 ponto importante, entretanto, è que o rearranjo dos recepto res para concanavalina $A$, presentes na membrana, "per se"não é suficiente para desencadear o crescimento e, portanto,este 
provavelmente, não é o evento iniciador do crescimento e divisāo celular.

5. Fator de crescimento de origen hipofisäria

En julho de 1971 nōs começamos a estudar as exigências de 3 in 3 para crescer em cultura. A razāo da escolha de 3T3 fora porque estas células mostram uma transiçāo muito nitida entre o estado de "repouso" e a fase de "proliferação". Um ensaio quantitativo para esta transição foi eslaborado e uma anälise sistemātica dos fatores que influenciam nessa transiçāo foi iniciada. Dessa investigaçāo resultou um desenvolvimento experimental oportuno e significante: o tecido hipofisārio possui un fator proteico que desencadeia crescimento em $3 \mathrm{~T} 3$, comportando-se como lama proteina reguladora do crescimento, a qual è diferente de todos os hormônios proteicos clāssicos da hipófise e ét făcil de purificar;além disso glucorticoides, em concentrações fisiológicas, agem como potenciadores da atividade dessa proteỉna (ARMELIN, 1973). Estas observações tinham, pelo menos, duas implicaçöes de nature za fundamental: primeiro, do ponto de vista prático ofereciam um caminho mais simples e realizävel a curto prazo, para o isolamento e purificação de um fator regulatório do crescimen to, do que o fracionamento do soro;e,segundo,do ponto de vista conceitual sugeria uma natureza definida para os fatores de crescimento de cēlulas de mamifero, ou seja, reguladores de natureza hormonal, talvez uma nova classe de fatores endöcri nos; hipótese excitante e de interesse básico, a qual merecia estudos cuidadosos.os resultados nossos jä foram completamente confirmados em outros laboratörio (GOSPODAROWICZ, 1974, HOLIEY e KIERNAN, 1974) e ao que tudo indica parecem ser fatos experi mentais incontestāveis. Sua significāncia para a fisiologia 
"in vivo" ẻ, evidentemente, questão ainda a ser respondida.

6. Mecanismos intracelulares de controle de crescimento

E razoável assumir que sejam quais forem os fatores extracelulares que interfiram com o cxescimento celular, eles necessariamente terão o seu efeito mediado por algum mecanismo intracelular. E comum admitir que tal mecanismo seja muito simples e talvez envolva apenas um mediador cujo nivel intracelular determinaria a velocidade de proliferação. Temse encontrado evidências experimentais em favor de dois tipos de mediadores: nutrientes e nucleotidios ciclicos. CUNNINGHAM e PARDEE (1969) mostraram, que um dos primeiros efeitos obser váveis na estimulaçäo com soro de $3 T 3$ "normal" e em repouso é a ativaçāo do transporte de nutrientes bāsicos como fosfato $\underline{i}$ norgānico,glicose e uridina; ao mesmo tempo os mesmos autores notaram que a atividade de transporte em 3 T3 transformada por virus permanece constantemente alta. Estes resultados e outros semelhantes (SEFTON e RUBIN, 1971; WEBER, 1973) tem sido inter pretados como indicando que o crescimento celular é simplesmen te determinado pelos niveis intracelulares de alguns nutrientes fundamentals e o controle do crescimento é exercido atravës dos sistemas de transporte; um autor que levou esta hipötese ao seu extremo fol HOLIEY (1972). Um problema com esta hipōtese è que è muito difícil de testā-la na prātica de maneira simples e não ambígua. Uma discussão mais ampla desta hipōtese e opçōes alternativas já foram apresentadas em outras seç̧ões desta tese (ver Capítulo II.d). outro tipo de raciocinio admite que a variação dos niveis intracelulares dos nutrientes è fenômeno 
$-73-$

secundărio, embora obrigatörio. A hipōtese aqui assume que existe um mediador central e os candidatos a essa função, que recentemente ganharam mais popularidade, säo os nucleotidios ciclicos; CAMP e CGMP. As evidências experimentais em favor disso são, por ordem cronolōgica: i) a adição de cAMP e teofilina ao meio de cultura de fibroblastos transformados por virus primeiro, induz a morfologia de fibroblastos "normal" e segundo inibe o crescimento da população (JOHNSON, FRIEDMAN e PASTAN, 1971; SHEPPARD; 1971; HSIE e PUCK, 1971); ii) as linhas celulares cujas velocidades de crescimento em cultura são mais altas correspondem os niveis intracelulares de CAMP mais baixos, assim como a transformação por vỉrus leva a diminui çäo do nỉvel de CAMP (OTTEN JOHNSON e PASTAN (1971); OTTEN et al (1972); iii) nos primeiros minutos depois da ativaçāo do crescimento em Iinföcitos com hemaglutinina o nivel intracelü lar de CGMP eleva-se abruptamente (HADDEN et al, 1972), o mesmo sendo observado para 3 T3 ativada com reguladores de crescimento (ARMEIIN, NISHIKAWA e SATO, 1974) ou com ésteres de forbol (ESTENSEN et al, 1974).

Quanto a observação de que cAMP e teofilina inibem o crescimento de fibroblastos transformados em cultura parece ser uma interpretação apressada: realmente o nucleotílio inibe o aumento de população, mas em grande parte a inibição se deve a indução de morte das células (ver resultados no Capí tulo anterior e neste). Isto tornaria a primeira evidência experimental citada acima invalidada. Jã as correlaçōes obser vadas entre as variações dos nivels intracelulares de cAMP e CGMP e o crescimento, são ainda evidências circunstanciais. 
b. Objetivos experimentais

Dados os antecedentes que o histórico anterio indica tornou-se oportuno e importante levar avante a caract rização do fator proteico de origem hipofisäria, o qual podi se mostrar como um protótipo de proteina reguladora do cresc mento de fibroblastos. Levando em conta as vantagens que sistema $3 T 3$ oferece como modelo experimental este poderia le var a informações bãsicas de interesse geral na regulação d crescimento e divisão celular em mamiferos.

Especificamente os seguintes pontos foram colo cados para investigação: i) determinação da atividade do fa tor na ausência de soro; ii) verificar se hä sinergismo co hormônios clāssicos, principalmente insulina; iii) medir tempo de duraçāo de Gl e o tempo de crescimento e duplicação da célula em diferentes condições; iv) verificar se o fato "induz" a célula a ficar "bioquimicamente comprometida" co a sintese de DNA e v) medir o efeito do fator no nivel intra celular de CAMP e CGMP, assim como verificar o efeito de adi ção do fator e os nucleotíios ao meio de cultura. Supunha se que os pontos $i$ e iv deveriam fornecer elementos para a $c$ racterização experimental de um protótipo de "regulador extr celular do crescimento"; ao mesmo tempo as informaçōes a se rem obtidas serviriam para testar algumas das predições do $\mathrm{m}$ delo de "ciclo celular" proposto nas secçōes b e c do Capitu $10 \mathrm{II}$. As experiências referentes ao ponto $\mathrm{v}$ poderiam traze. alguma informação interessante para a definição dos mecanis mos intracelulares de controle do crescimento. A secção se guinte relata os resultados obtidos na tentativa de execução deste plano experimental. 
c. Resultados

1. Efeito da ausência de soro na sintese de DNA de células "normais" e transformadas

Tanto células 3 T3 "normais" como as transformadas por virus (SV3T3) necessitam de soro para sobreviver e crescer em cultura. Mas, o efeito da retirada do soro do meio de células que crescem ativamente, tem uma diferença fun damental entre os dois tipos de célula: nas primeiras 6 a 8 horas depois da retirada do soro a sintese de DNA em 3 TT3 permanece alta, mas cai em sequida e é nula depois de 12 horas; em SV3T3, entretanto, a sintese de DNA não mostra tendência a diminuição. A ausência de síntese em células "normais" não é devido à morte mais rápida destas células na falta de soro, pois a sintese de DNA pode ser reiniciada, depois de 12 hcras, se ur "regulador de iniciação", apropriado, for adicionado ao meio de cultura; por outro lado, o mesmo "regulador"não tem efeito sobre a sintese de DNA em célula transformada, conforme os resultados da Tabela VII indicam. Estes resultados podem ser, inicialmente, interpretados da seguinte maneira: cēlulas 3T3 "normais"levam avante replicação de DNA já inicia da, mesmo na ausência de soro, mas para a iniciação de sintese dependem de "reguladores" fornecidos pelo soro: já células transformadas são independentes de "reguladores de ini ciação" para iniciar síntese de DNA.

2. Fatores extraidos da hipófise: natureza e especificidade

Como nös descrevemos anteriormente (ARMEIIN,

1973 ) extratos do tecido hipofisärio possuem um fator ou 
$-76-$

fatores proteicos, os quais estimulam a iniciação de sintese de DNA em fibroblastos e constituem espécies químicas diferentes dos hormônios hipofisārios clássicos. Preparações impuras de LH bovino fornecidas pelos National Institutes of Health (NIH-LH-B8 e B9 sāo, particularmente, ricas em espê cies ativas). NIH-LF-B8, aparentemente, contēm diversas espẹ cies ativas com pI de neutro $(6,6)$ a básico $(8,7)$, como "ele trofocusing analysis" indicou (K. NISHIKAWA e H.A. ARMELIN, re sultados não publicados). Resultados ainda mais claro em favor de diversas espēcies ativas foram obtidos pela extração direta do tecido pituitārio fresco. As extrações foram feitas segundo um processo baseado no método estabelecido para se paração das gonadotropinas (ver Tabela VIII). Este processo permite a obtenção de uma fração (fração 5 da Tabela VIII) 10 a 20 vezes mais ativa que NIH-IH-B8; esta fração, quando cromatografada em carboximetilcelulose, dá atividades que se separam claramente (ver Tabela VIII), indicando a presença de diversas espēcies químicas independentes. Portanto, o tecido da pituitäria fornece atividades, as quais aparentemente envolvem diversos fatores independentes. Esta mistura de diver sas entidades quimicas mostra atividade, a qual não è específica para as espécies animais: extrações de origem bovina e ovina estimulam células de camundongo, rato, coelho e homem; elas também estimulam diversos tipos de cêlulas: fibroblastos (ARMELIN, 1973; GOSPODAROWICZ, 1974; HOLLEY e KIERNAN, 1974), condrócitos (CORVOL et al, 1972; R.L. JONES, comunicação pessoal), células gliais (GOSPODAROWICZ, 1974; NISHIKAWA, ARMELIN e SATO, 1974) ovarianas (ARMELIN e SATO, 1973) e adre nais (H. MASUI, comunicação pessoal); resultados que sugerem ausência de especificidade por tipo de célula. Não obstante 
$-77-$

a mistura de fatores hipofisärios poderia constituir uma população de fatores, os quais isoladamente seriam especificos para cada tipo de cēlula, entretanto, os dados nossos e os de outros investigadores, que nos fol dado saber não são suficientes para decidir esta importante questão.

GOSPODAROWICZ (1974), por um processo ainda não totalmente divulgado, purificou uma proteina a partir das fra ̧̧ōes básicas obtidas de CMC pelo método indicado na Tabela VIII; esta é una proteína bäsica de peso molecular 13.000, a qual o autor descreve como um fator de crescimento para flbro blastos. Para simplificar a descrição de resultados neste Ca pitulo, NIH-LH-B8, NIH-LH-B9 ou qualquer outra fração hipofisārla serão chamados FI (significando fração impura); o fator de GOSPODAROWICZ para flbroblastos será chamado FP(significan do fração pura).

3. Iniciação de sintese de DNA em células "normais" na ausência de soro

Conforme os resultados descritos na seç̧ão 1 in dicaram as células"normais" tendem a entrar em repouso quando privadas de soro. Para obter células em repouso ("estado R") em meio com baixa concentraçāo de soro (MBCS) ou na completa ausēncia de soro, para fins de ensaio de "reguladores" da ini ciação da sintese de DNA, o seguinte protocolo foi elaborado: 


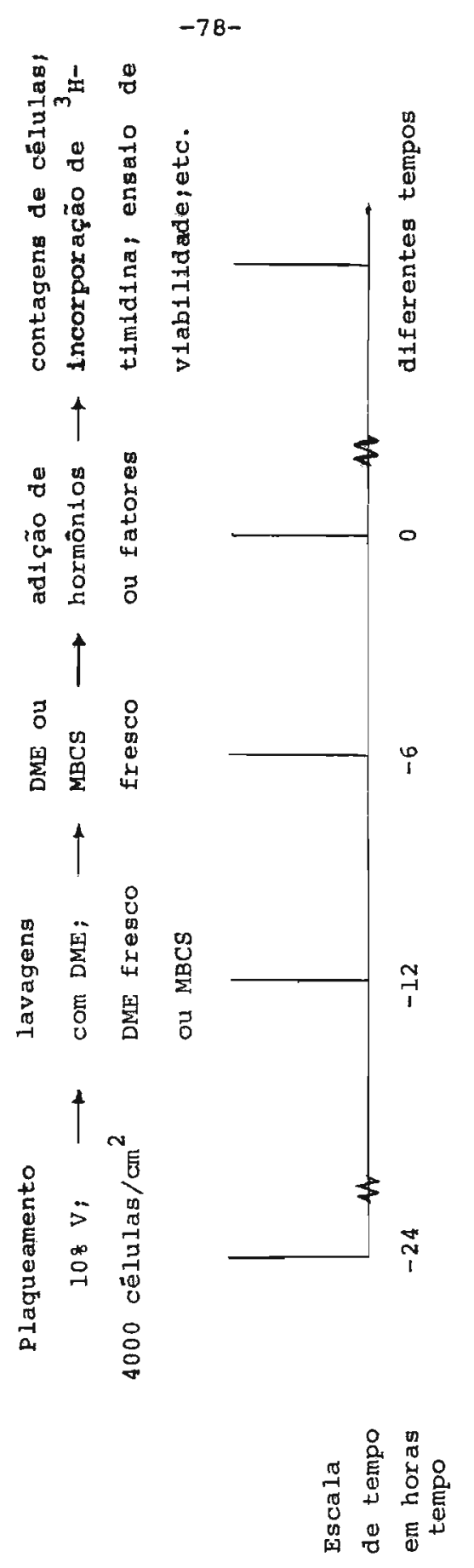


$-79-$

A mistura de fatores da hipöfise (FI), insulina e hidrocortisona estimulam a iniciaçāo da sintese de DNA em células 3 T 3 en repouso, mesmo na completa ausência de soro. A Figura 10 mostra a estimulação da incorporação de ${ }^{3} \mathrm{H}$-timidina em DNA por diferentes combinações destes fatores. Todos os fatores foram adicionados juntos no tempo zero. Insulina e hidrocortisona não tem atividade isoladamente ou juntas, mas ambos aumentam a atividade de FI (Figura $10 \mathrm{~b} e \mathrm{c}$ ); enquanto FI tem atividade quando adicionado sozinho. se antes da adição de FI, as células forem incubadas com insulina e hidrocortisona (12 ou 24 horas), a resposta è a mesma que quan do todos os fatores são colocados juntos como na Figura 10a.. A Figura 11 reune os resultados obtidos com o uso de FP(fator hipofisärio purificado). O fato importante nestes resultados é que FP, insulina e hidrocortisona estão funcionando em concentrações fisiolögicas e na completa ausēncia de soro. E in interessante comparar estes resultados com efelto do fator epiäermico ou epitelial de crescimento (EGF); este fator é uma proteina encontrada em glāndulas salivares de roedores, a qual foi purificada até homogeneidade e foi descrita como um fator que promove crescimento de células epiteliais, princi paimente epidērmicas (COHEN, 1962). Entretanto, foi possivel verificar que EGF estimula a sintese de DNA em fibroblastos de camundongo (ARMELIN, 1973) e humanos (HOLIENBERG e CUATRECASAS, 2973), em concentrações fisiolögicas; esta ativí dade, no entanto, era muito baixa, sendo discutivel e sua sig nificância. Tentando verificar o significado do efeito de EGF em fibroblastos nös investigamos se insulina e hidrocorti soma tinham, tambēm, algum efeito sinergistico com este fator. Os resultados foram sistematicamente negativos sugerindo que 
$-80-$

não hā nenhum sinergismo entre EGF, Insulina e hidrocortisona na estimulação da sintese de DNA em fibroblastos.

E importante lembrar que jà hà algum tempo tinha sido observado que a atividade estimante do soro podia ser parcialmente substitulda por insulima (TEMIN, 1967; CLAR KE et a1, 1970; HERSHKo et a1, 1971; ASUA et a 1, 1973). Em todos estes casos, entretanto, jarsulina sō era ativa em con centrações muito altas, algumas ordens de magnitude maior que os niveis fisiológicos; fato que coloca dúvidas no significado deste efeito. Dúvidas deste tipo não existem no caso do efelto sinergistico de insulina descrito aqui.

4. Medidas de $G 1$ e do tempo de crescimento e dupli cação da célula

Dado que FI, insulina e hidrocortisona estimulam as células a iniciarem síntese de DNA a pergunta que se colocou foi: a duração de Gl e o tempo de crescimento e duplicação da cêlula variam com a presença ou a concentração do soro? Me didas destes parâmetros foram efetuadas e os dados obtidos apa recem na Tabela IX. Como se pode notar a duração de Gl é completamente independente da presença de soro. Jā o tempo de duplicação é independente da concentração do soro por um grande intervalo de concentração, mas em meio inteiramente isento de soro a divisão não se completa; este ponto vai ser retomado abaixo na secção 6 .

Deve-se acrescentar que foi tambêm verfficado que a duração de Gl è também independente da concentração de "reguladores", como indicaram experiênclas efetuadas com concentrações de FI inferiores à concentração "saturante". 
$-81-$

5. Frequência de cēlulas estimuladas a inicior sīn tese de DNA

Desde que a duração de Gl não varia, era razoāvel esperar que as diferenças na magnitude de resposta verifi cadas nos resultados das figuras 10 e 11 , fossem devidas a va riações da frequência de cêlulas estimuladas. As frequências de cēlulas estimuladas em diversas condições foram medidas por autorradiografia; os resultados obtidos aparecem na Tabe la $\mathrm{X}$ (ver tambēm Figura 12a). Os resultados mostram que os efeltos sinergisticos de insulina, hidrocortisona e 0,258 de soro são devidos a un nümero mator de células que intciam sinn tese de DNA. Estes resultados são claramente opostos à suges tão de GOSPODAROWICz (1974).

\section{6. "Terminação" e divisão celular \\ Os dados da Tabela IX mostraram que a sintese} de DNA E infciada na ausêncla de soro, mas a população não au menta nestas condiçöes; restava saber se o bloquelo do cresci mento ocorria num ponto definido de S, G2 ou M. Para verificar isso experiências cinéticas foram feltas seguindo-se a sintese de DNA (Figura 12a), o crescimento da população de cế lulas (Figura 12b) e a viabilidade celular (Figura 12c). 958 das cēlulas que receberam hormônios mais soro no tempo zero, iniciaram sintese de DNA (Figura 12a) e começaram a se dividir a 23 horas (Figura 12bj, a 26 horas a população jä tinha dobrado. 418 das cēlulas tratadas somente como hormônios no tempo zero estavam sintetizando DNA a 16 horas (Figura 12a); nestas condições o nümero de cëlulas aumentou muito pouco, mas um surto de divisão ocorreu menos de duas horas depols da 


$$
-82-
$$

adiçāo de soro; tendo o resultado sido o mesmo para soro adicionado a 24 or a 30 horas (Figura 12b). Os incrementos em nümero de células foram os máximos esperados considerando a quantidace de células que iniciaram sintese de DNA (418 - Figura 12a). A viabllidade celular durante este tipo de experiência foi medida pela capacidade de desenvolver colônta (Fí gura 12c). Na ausência de soro a viabilidade cal progresstva mente; os hormônios aiminuer a velocidade da morte celular mas eles não são suficientes, para garantir a sobrevivência - aumento em viabilidade para as células, as quais receberam soro a 24 e 30 horas, indica que a descendência das células que se dividiram era viável. Estes resultados mostram que as células que iniciam crescimento (começo de Gl) progridem até - fim de G2 ou começo de mitose, mas a eficiente "terminação" do processo depende de um fator do soro.

7. Desencadeamento do crescimento celular e "com prometimento bioquimico" para iniciar sintese de DNA

Os resultados apresentados nas secçōes anteriores, sugerem que existem reações iniciais as quais determinam - desencadeamento do crescimento celular e ou o "comprometi mento bioguímicon para iniciar sintese de DNA; sugestão esta que coloca a interessante possibilidade de que os "reguladores extracelulares de iniciação"sejam necessārios apenas para des desencadear as reaçōes intciais, podendo ser eliminados em se guida. Para un teste inicial desta hipótese fizemos tratamen tos curtos das células com FI, lavando-as extensivamente en seguida e acompanhamos a iniciação da síntese de DNA pela incorporação de ${ }^{3}$ H-timiaina. Verificamos que para células em repouso, em meio com 0,58 de soro, FI é eficiente mum 


\begin{abstract}
$-83-$
tratamento tão curto quanto 10 minutos; alërn disso tratamentos mais longos como 30 e 60 minutos dão zesultados iguais, conforme a Figura 13 claramente mostra. Estes resultados sugeriram que o "desencadeamento" ou "comprometimento bioquimico",como aventado acina,talvez exista e ocorre nos primeiros minutos de ação dos "reguladores". Entretanto, quando a mesma ex periência foi feita com cêlulas em repouso em meio isento de soro nenhuma estimulação da sintese de DNA foi observada: FI sozinho ou em combinação com insulina e hidrocortisona foram tentados em tratamentos que vartavam de 10 a 60 minutos;insulina e hidrocortisona foram testados antes, durante e ou após - tratamento com FI, mas em nenhum caso houve estimulação sig nificante da sintese de DNA. Não vemos nenhuma explicação sim ples para esse comportamento e certamente mais experiências são necessárias para entendermos esse problema.
\end{abstract}

8. Nucleotidios cíclicos e o mecanismo de ação dos reguladores

A adição de dibutiril-cAMP $\left(10^{-3} \mathrm{M}\right)$ ou teofilina $\left(10^{-3} M\right)$ ou ambos ao meio de cultura de $3 T 3$ e SV3T3, espar sos e crescendo em $108 \mathrm{~V}$, levou à inibição do crescimento da população; observação que concorda com o descrito por SHEPPARD (1971) e pelo laboratório de PASTAN (JOHNSON et al, 1971). Foi possivel notar, entretanto, que no caso dos fibroblastos transformados, parte considerāvel do efeito inibitörio deve-se à morte celular, enquanto que os fibroblastos "normais" tiveram inibição de crescimento sem apreciável perda da viabilida de. Isto mostra que, primeiro, sv3T3 se comporta de maneira semelhante as células neoplästicas de origen mamäria, objeto do estudo descrito no Caoítulo IV, e, segundo, SV3T3 não 
"readquire" o comportamento de células "normais" quando tratado com CAMP, conforme anterlormente sugerido (SHEPPARD, 1971; Jomnson et al. 1971).

Os nifeis intracelulares de CAMP e cGMP de célu las 373 era repouso (meio $0,58 \mathrm{~V}$ ), foram medidos nos primeiros 30 minutos depols da adlção de FI e hidrocortisona ao meio de cultura; resultados são apresentados na Tabela XI. Os resultados indicam que os niveis de CAMP caem enquanto os de cGMP aumentam; hidrocortisona não tem nenhum efeito sozinha, mas tem o efeito de aumentar a atividade de FI, o que acompanha - observado para a estimulação de sintese de DNA. Os resulta dos encontrados para CAMP estavam dentro das expectativas,vis to que os dados da literatura recente eram equivalentes. Por outro lado, o aumento de CGMP não era necessariamente esperado; quando nós estaxamos obtendo nossos primeiros resultados, - laboratörio de Goldberg (HADDEN et al, 1972) publicou o pri meiro resultado deste tipo na literatura: estes investigado res verlficaram que quando linföcitos são atıvados para crescer cam fitohemaglutinina, o nivel de cGMP tem um aumento brus co logo nos primeiros minutos de tratamento. Nossos resulta dos com fibroblastos concordaram com os obtidos para linföci tos e foram os primeiros observados com "regulador" de cresci mento de caracteristicas fisiológicas. E interessante mencio nar que os niveis de CGMP foram baixos (2 a 3 vezes 0 nivel das células en repouso) no fim de Gl ( 10 horas), e no melo de S (15 horas), tendo sido estes os üntcos tempos medidos alẻm do Infcio de Gl. E desnecessário dizer que lsto não prọa que cGMP è o intermodiărio intracelular dos "reguladores" de iniciação do crescimento; estes resultados, entretanto,mog traram que o aumento de. CGP e um dos primeiros 
$-85-$

eventos bioguimicos do início de $\mathrm{Gl}$, pelo menos para linfócitos e fibroblastos.

Se CGMP fosse o iniciador intracelular primärio do crescimento (sendo o aumento de cGMP o evento que torna a cēlula "bioquimicamente comprometida" com a sintese de DNA) era de se esperar que a adição deste nucleotídio ao melo de cultura, levaria à estimulação de sintese de DNA em cēlulas "normais", em repouso. Pudemos observar que cGMP, a $10^{-6} \mathrm{M}$ no meio de cultura, aumenta de 3 a 4 vezes o nivel basal de sintese de DNA em $3 T 3$, mantida em meio $0,58 \mathrm{~V}$, mas este efeito não aumenta com a concentração de CGMP (até $10^{-3} \mathrm{M}$ ) e na mesma experiência FI $(500 \mathrm{ng} / \mathrm{ml})$ causou uma estimulação de 19 vezes o nivel basal da sintese de DNA. Neste tipo de expe riência os resultados mostraram claramente que, quantitativamente, CGMP não mimetiza os "reguladores" extracelulares, res ta saber qual o significado do pequeno efeito estimulatório de CGMP; infelizmente não temos resposta clara para isso. Deve-se levar em conta que dibutiril-cAMP usado nas mesmas condiçōes $\left(10^{-3} \mathrm{M}\right.$ no meio de cultura), tambēm tem pequeno efeito estimulatório, e a adição de DicAMP $\left(10^{-3} \mathrm{M}\right)$ mais cGMP $\left(10^{-6} \mathrm{M}\right)$ dá o mesmo resultado de CGMP sozinho, is to é, pequenos efeitos estimulatörios são observados com ambos nucleotídios, mas quando colocados juntos os efeitos não se somam.

Finalmente, como nota de rodapé a esta secção de resultados trazemos os dados reunidos na Tabela XII. Estes dados foram obtidos através de experiências, nas quais nos valemos do fato de que tratamentos curtos com FI(como des crito acima em 7), estimulam sintese de DNA em 3T3, em melo $0,5 \% \mathrm{~V}$. Resposta a duas perguntas foram visadas nestas 
experiências: primeiro, tratamentos curtos com cGMP, segulndo o mesmo protocolo usado para FI, tem algum efeito?; segundo, qual a consequência da adição de DicAMP, durante ou depois do tratamento com FI, para a estimulação da sintese de DNA causada por FI? Quanto à primeira questão a resposta é clara: cGMP não tem nenhum efeito na sintese de DNA e portanto não mimetiza FI em tratamentos curtos. Já a resposta à segunda questão não fol tão clara. Se tomarmos os dados normalizados estes sul gerem que: 1) DicAMP junto com FI por 10 minutos causa pequena inibição, a qual aumenta se o tratamento for por 180 minutos; ii) jā a adição de DicAMP ao meio após o tratamento com FI, Ie va a completa inibição se o tratamento for por 10 minutos, mas causa o aumento do efeito estimulatório de FI se o tratamento for por 180 minutos. Evidentemente, neste estägio, qualquer interpretação destes resultados será preliminar, não obstante, os dados e o tipo de experiência são interessantes e merecem ser explorados. Se assumirmos que o efeito de DicAMp se deve exclusivamente ao aumento do nivel intracelular de cAMP (pre missa não necessariamente verdadeira), podemos dizer que entre as implicações novas que os dados acima sugerem, estão: i) a queda do nível de caMp não está entre os eventos mais ini ciais de GI, mas a gueda é un evento necessário que ocorre nos primeiros 30 minutos; ii) parece que entre os efeitos diretos de FI está a queda do nível de cAMr, pois a adição de DicAMP apös 10 minutos causa 1008 de inibição ras a adição junto com FI por 180 minutos causa apenas $50 \%$ de inibição. Certamente estas implicaçōes podem e devem ser testadas na prática. 


\section{a. Conclusōes}

1. Um dos objetivos präticos deste trabalho era a caracterização experimental de "regulador de cresci mento", cuja existência, embora provăvel, era essencialmen te postulada. Parece-nos justo dizer que os resultados apresentados formam um substrato experimental sölido, qualificando o fator proteico de origem hipofisária como un protótipo de proteina reguladora do crescimento de fibroblastos em cultura. Muito interessante foi a demonstração de que insuli na e hidrocortisona agem sinergisticamente com este fator em concentrações fisiolögicas; dentro do que nós sabemos, resultados claros indicando o efeito de insulina ou hidrocortisona no crescimento celular, em concentrações fisiológicas, nun ca foram descritos.

2. Os resultados mostraram que: i) o crescimento de cēlulas "normais" è primariamente dependente de fatores que regulam a iniciação do crescimento por "controle positivo"; Ii) a duraçāo de Gl e o tempo de crescimento e duplicação, parecem ser parâmetros intrísecos da célula e indepen dentes dos reguladores extracelulares do crescimento; iii) o conceito de "comprometimento bioguímico" (embora não tenha sido experimentalmente demonstrado no inicio de GI) pode ter significado real e certamente è uma ferramenta ütil na elaboração racional do ataque prātico. Estes fatos sem dūvida estão de acordo com algumas das previsões do modelo do ciclo celular sugerido no Capitulo II.

3. A descoberta de que CGMP tem seu nivel grandemente elevado no inicio do crescimento celular tem duplo in teresse: i) contribui para a caracterizaçāo das reações do 
Inicio de Gl, caracterização essa necessária para elucidar os mecanismos intracelulares que regulam o crescimento, e ii) è interessante para o estudo da função geral de CGMP no metabolismo, pois este nucleotidio, embora descoberto a mais de 10 anos e ser de ocorrência geral, contrariamente a cAMP ainda não tem função metabólica conhecida (ver ROBISON, BUTCHER e SUTHERIAND， 1971).

4. Os resultados mostraram que cëlulas transformadas por vĩrus não tem a tendência de entrar em repouso, quando privadas de soro, parecendo terem a iniciação da sintese de DNA independente de reguladores extracelulares. Estas observaçōes tem interesse imediato para a compreensão do compor tamento das células cancerosas. 
TABELA VII

\begin{tabular}{llc}
\hline Célula & $\begin{array}{l}\text { Regulador } \\
\text { adicionado } \\
\text { ao DME }\end{array}$ & $\begin{array}{l}\text { 3 H-timidina incorporada entre } 12 \text { e } 24 \\
\text { horas depois da transferengia para } \\
\text { meio soro, em cpm/10 células }\end{array}$ \\
\hline SV3T3 & nenhum & 11.000 \\
FI & 10.000 \\
3 nT3 & nenhum & 250 \\
& FI & 9.200 \\
\hline
\end{tabular}

Efeito da ausência de soro no meio de cultura sobre a sintese de DNA em fibroblastos "normais" (3T3) e em fibroblastos transformados por virus (SV3T3). As células foram plaqueadas em $108 \mathrm{~V}, 24$ horas depois foram lavadas extensivamente com meio sem soro (DME) e incubadas com DME ou DME + FI (1000 ng/ml). ${ }^{3} \mathrm{H}$-timiaina $\left(1 \times 10^{-5} \mathrm{M}, 1 \mu \mathrm{C} / \mathrm{ml}\right)$ fol adicionada ao meio 12 horas depois da passagem para DME e incorporaçāo foi permitida pelas 12 horas seguintes. 
$-90-$

TABELA VIII

\begin{tabular}{|c|c|c|}
\hline $\begin{array}{l}\text { Nūmero da } \\
\text { Eração }\end{array}$ & Fraçōes & $\begin{array}{l}\text { Atividades especi- } \\
\text { ficas (unidade/ } / \text { g) }\end{array}$ \\
\hline 1 & $\begin{array}{l}\text { Sobrenadante } \\
\mathrm{pH} 4,0 ;\left(\mathrm{NH}_{4}\right)_{2} \mathrm{SO}_{4} 0.25 \mathrm{M}\end{array}$ & 0,08 \\
\hline 2 & $\begin{array}{l}\text { Sobrenadante } \\
\mathrm{pH} 7,0 ;\left(\mathrm{NH}_{4}\right)_{2} \mathrm{SO}_{4} 0,15 \mathrm{M}\end{array}$ & 0,18 \\
\hline 3 & $\begin{array}{l}\text { Precipitado } \\
\left(\mathrm{NH}_{4}\right)_{2} \mathrm{SO}_{4} 2,2 \mathrm{M}\end{array}$ & 0,11 \\
\hline 4 & $\begin{array}{l}\text { Precipitado } \\
\left(\mathrm{NH}_{4}\right)_{2} \mathrm{SO}_{4} 4,9 \mathrm{M}\end{array}$ & 0,70 \\
\hline- & NIE-IE-B8 & 1,00 \\
\hline 5 & Fraçāo colocada na coluna de CMC & 13,00 \\
\hline 6 & $C M C-F_{1}$ & 20,0 \\
\hline 7 & $C M C-F_{2}$ & 1,0 \\
\hline 8 & $C M C-E_{3}$ & 3,5 \\
\hline 9 & $\mathrm{CMC}-\mathrm{F}_{4}$ & 1,0 \\
\hline 10 & $C M C-F_{5}$ & 6,0 \\
\hline
\end{tabular}

Veja legenda à página seguinte. 
$-91-$

LEGENDA DA TABELA VIII

Atividade estimulatōria da iniciaçāo de sintese de DNA em fraçōes extraídas do tecido hipofisārio. As fraçōes foram obtidas segundo o processo de D. GOSPODAROWICZ, o qual é baseado em métodos estabelecidos para purificação de LH e FSH (PAPKOFF et al, 1965; GOSPODAROWICZ e PAPKOFF, 1966; PAPKOFF, GOSPODARO WICZ e LI, 1967). Sumariamente, O processo envolveu as seguin tes etapas: homogeneização do tecido hipofisário bovino congelado em $\left(\mathrm{NH}_{4}\right)_{2} \mathrm{SO}_{4} 0,15 \mathrm{M}, \mathrm{pH} 4,5$ (fraçāo 1); residuo removido e sobrenadante feito $\mathrm{pH} 3,0$ com $\mathrm{HPO}_{3} 0,5 \mathrm{M}$; precipitado eliminado e sobrenadante ajustado a pH $6,5-7,0 \mathrm{com} N a O H ~ I N$ (fracão 2); adicionado $\left(\mathrm{NH}_{4}\right)_{2} \mathrm{SO}_{4}$ para $2,2 \mathrm{M}$, precipitado recolhido (fração 3): sobrenadante feito. $\left(\mathrm{NH}_{4}\right)_{2} \mathrm{SO}_{4} 4,9 \mathrm{M}$, precipitado re colhido (fração 4) e sobrenadante eliminado; precipitados dissolvidos em āgua, dialisados contra ăgua e liofilizados; liofi lizado de $\left(\mathrm{NH}_{4}\right)_{2} \mathrm{SO}_{4} 4,9 \mathrm{M}$, dissolvido en água, feita $\mathrm{pH} 3,5$ com $\mathrm{HPO}_{3} \mathrm{O}, 1 \mathrm{M}$, sobrenadante eliminado, precipitado recolhido, aissolvido em água, ajustada para $\mathrm{pH} 7 ; 0$ com NaOH 0,I M, diali sada contra ägua e liofilizada; liofizado anterior dissolvido em fosfato de sódio $0,005 \mathrm{M} \mathrm{pH} \mathrm{6,0,} \mathrm{material} \mathrm{insolüvel} \mathrm{eli-}$ minado (Eração 5), e cromatografado em carboximetilcelulose (CMC); eluição: $F_{1}$, não adsorvida (fração 6 ); $F_{2}$, fosfato de sódio $0,05 \mathrm{M}, \mathrm{pH}^{\mathrm{H}, 0}$ (Eração 7); $\mathrm{F}_{3}$. fosfato $0,1 \mathrm{M}, \mathrm{pH} 6,0$ (fração 8) $\mathrm{F}_{4}$, fosfato $0,1, \mathrm{pH} 6,0, \mathrm{NaCl} 0,1 \mathrm{M}$ (fração 9); $\mathrm{F}_{5}$ fosfato $0,1, \mathrm{pH} 6,0 \mathrm{NaCl} 1 \mathrm{M}$ (fraçāo 10). Atividades medidas pela incorporação ${ }^{3} \mathrm{E}$-timidina de acordo com o protocolo das Figuras 10 e 11. Atividades especificas em unidades arbitrārias por micrograma; NIH-LH-B8 tomada como referência, tendo atividade especifica igual a um por definiçāo. Se o ensaio é efetuado em meio com 0,58 de soro em vez de 08 , os resulta dos são essencialmente os mesmos. 
TABEIA IX

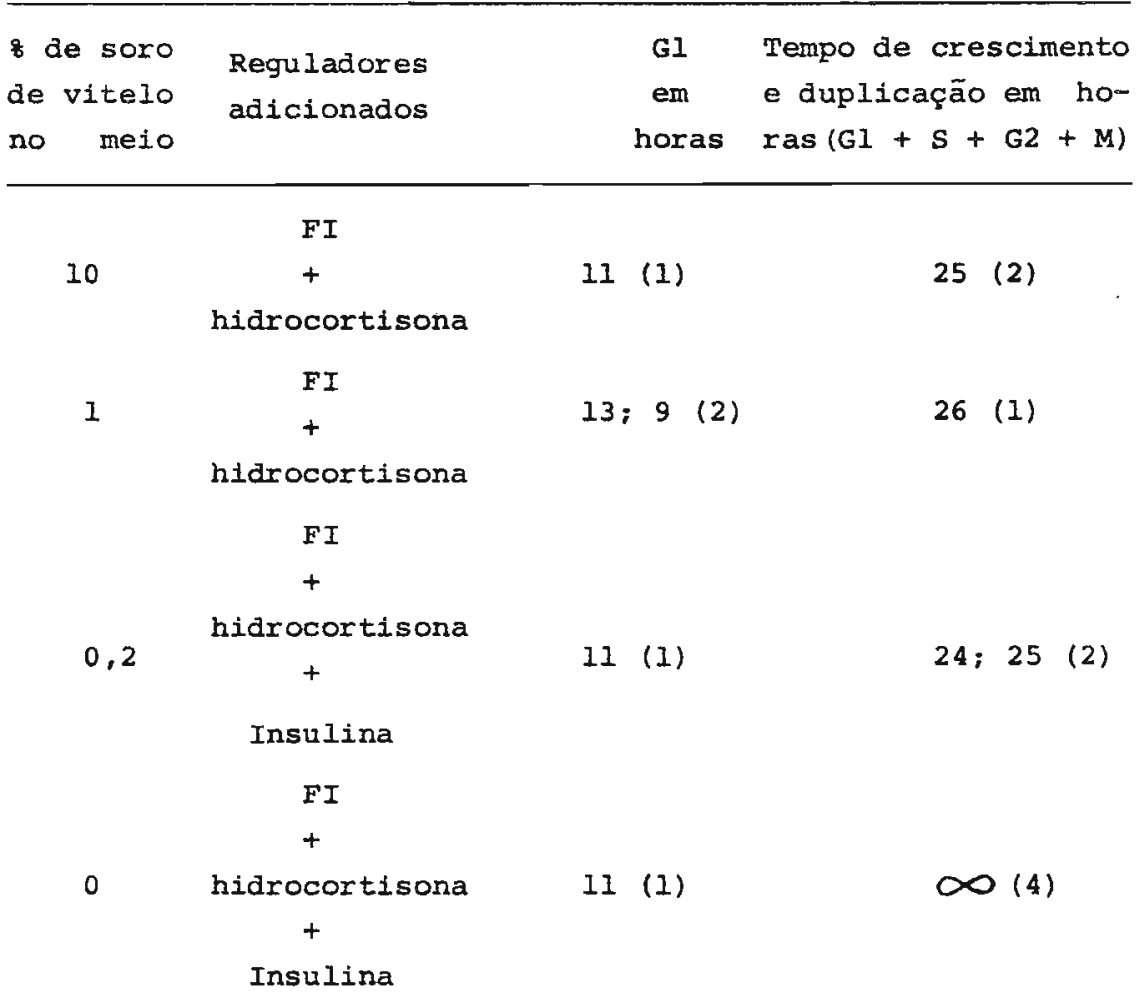

Estimativas do tempo de duração de Gl e do tempo de crescimento e duplicação das células (G1 + S + G2 + 1 ). Na experiência com 108 de soro de vitelo, as cêlulas foram plaqueadas e incubadas por 8 dias (sem mudança de meio); depois deste tempo o crescimento era nulo e neste ponto as células foram reestimula das com FI e hidrocortisona. Nas experiênclas com 18, 0,28 de soro as células foram plaqueadas inicialmente em 108 de soro, algumas horas depois transferida a $1 \%, 0,28$ ou $0 \%$ de soro e incubadas por 24 horas para as células entrearem em repou so, neste ponto os hormōnios foram adicionados. processo para

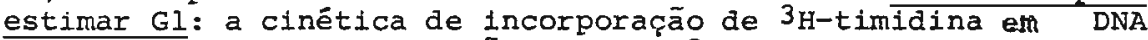
foi seguida depois da adição dos hormōnios (tempo zero); as medidas de incorporaçāo em cpm foram colocadas em gráfico em fun ção do tempo; os pontos entre os tempos 12 e 18 horas foram usados, tirando-se a reta média entre eles, a qual fol extrapo lada ao eixo dos $\mathrm{x}$, o ponto de intersecção deu a estimativa dê Gl. Processo para estimar o tempo de duplicacão: o tamanho da população em número de cellulas por placa, foi seguido em função do tempo apōs a adição dos hormônios; nas placas que não receberam hormônio o tamanho da população não variou; nas placas com hormōnio a populaçāo permanece constante até 23 a 25 horas e então aumenta bruscamente; o tempo correspondente ao aumento de 50 foi tomado como a estimativa do tempo de duplicação. Concentração dos hormônios: FI $1000 \mathrm{ng} / \mathrm{ml}$; hidrocortisona $100 \mathrm{ng} / \mathrm{ml}$ e insulina $50 \mathrm{ng} / \mathrm{ml}$. Os números entre parênteses indicam numero de experiências feitas. 
$-93-$

TABELA $\mathrm{X}$

\begin{tabular}{lc} 
Adiçöes ao DME (no tempo zero) & z de nücleos marcados \\
\hline Nenhuma & zero \\
Hidrocortisona (H) & 3 \\
Insulina (I) & 9 \\
Fator hipofisärio impuro (FI) & 0,4 \\
I + H & 31 \\
FI + F & 26 \\
FI + I & 49 \\
FI + I + H & 98 \\
FI + I H + O,258 soro de vitelo & 8 \\
O,258 soro de vitelo & 98 \\
108 soro de vitelo &
\end{tabular}

Frequências das cēlulas estimuladas a Iniciar sintese de DNA medida por autorradiografia. ${ }^{3} \mathrm{H}$-timidina foi incorporada en tre 12 e 24 horas depois da adição dos fatores às células em repouso no meio em soro (DME); após incorporação as placas foram processadas para autorradiografia. Os nücleos foram contados num microscópio de fase; duas placas por ponto; 200 a 300 núcleos contados por placa; FI: $1000 \mathrm{ng} / \mathrm{ml}$; hidrocort sona: $100 \mathrm{ng} / \mathrm{ml}$; insulina: $50 \mathrm{ng} / \mathrm{ml}$. 
TABEIAA XI

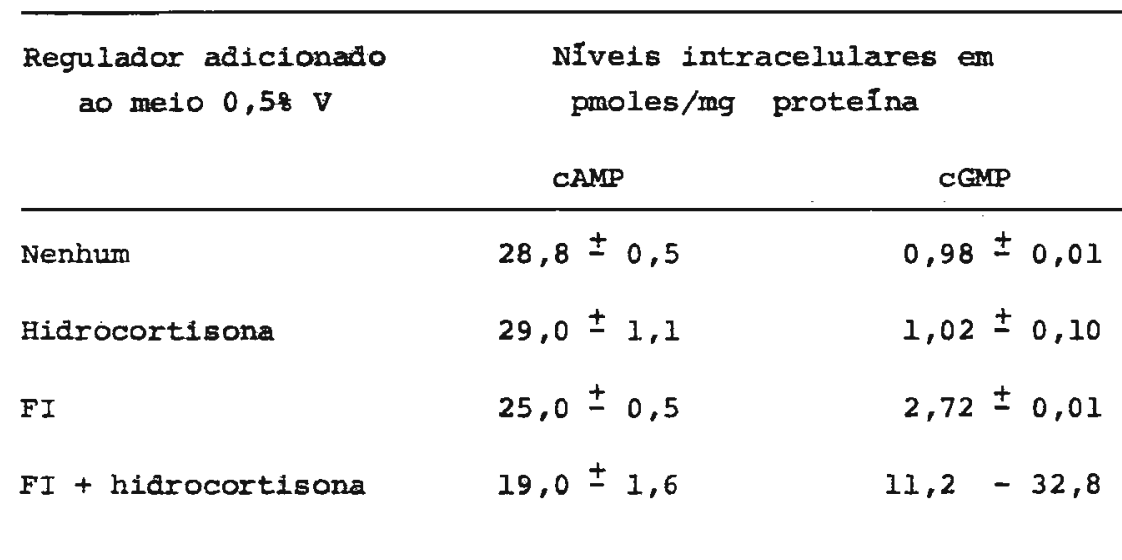

Medidas dos niveis intracelulares de cAMP e CGMP en células em repouso ("estado $R^{\prime}$ ), estimuladas pelo fator hipofisário (FI) e hidrocortisona. Células esparsas em repouso, em meio $0,58 \mathrm{~V}$ foram estimuladas com FI $(1000 \mathrm{ng} / \mathrm{ml})$ e ou hidrocorti sona (100 $\mathrm{ng} / \mathrm{ml})$, os quais foram adicionados à cultura no tempo zero; 30 minutos depois as cēlulas foram fixadas e ex traidas com TCA 108 , a $2^{\circ} \mathrm{C}$. Os dados da Tabela são médias de duas medidas experimentais totalmente independentes. A eficiência da extração foi estimada pela recuperação de

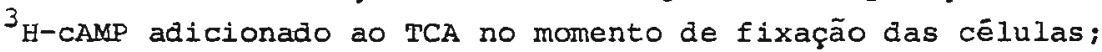
a medida de eficiência foi feita num grupo de placas parale las, dando $68 \pm 28$, esta estimativa foi assumida como válida para todas as extrações da mesma experiência e usada para a correção de todos os valores finais. Na experiência, cujos dados aparecem na Tabela, os nucleotídios não foram se parados antes do imunoensaio. No imunoensaio as "ativida des" de cAMP e de cGMP aumentavam linearmente com $\circ$ volume do extrato. Na experiência da Tabela as "atividades" de CAMP e CGMP foram 90 a 958 eliminadas com a fosfodiestera se de coração bovino, mas apenas dois extratos foram testa dos e o resultado considerado välido para os demais. 


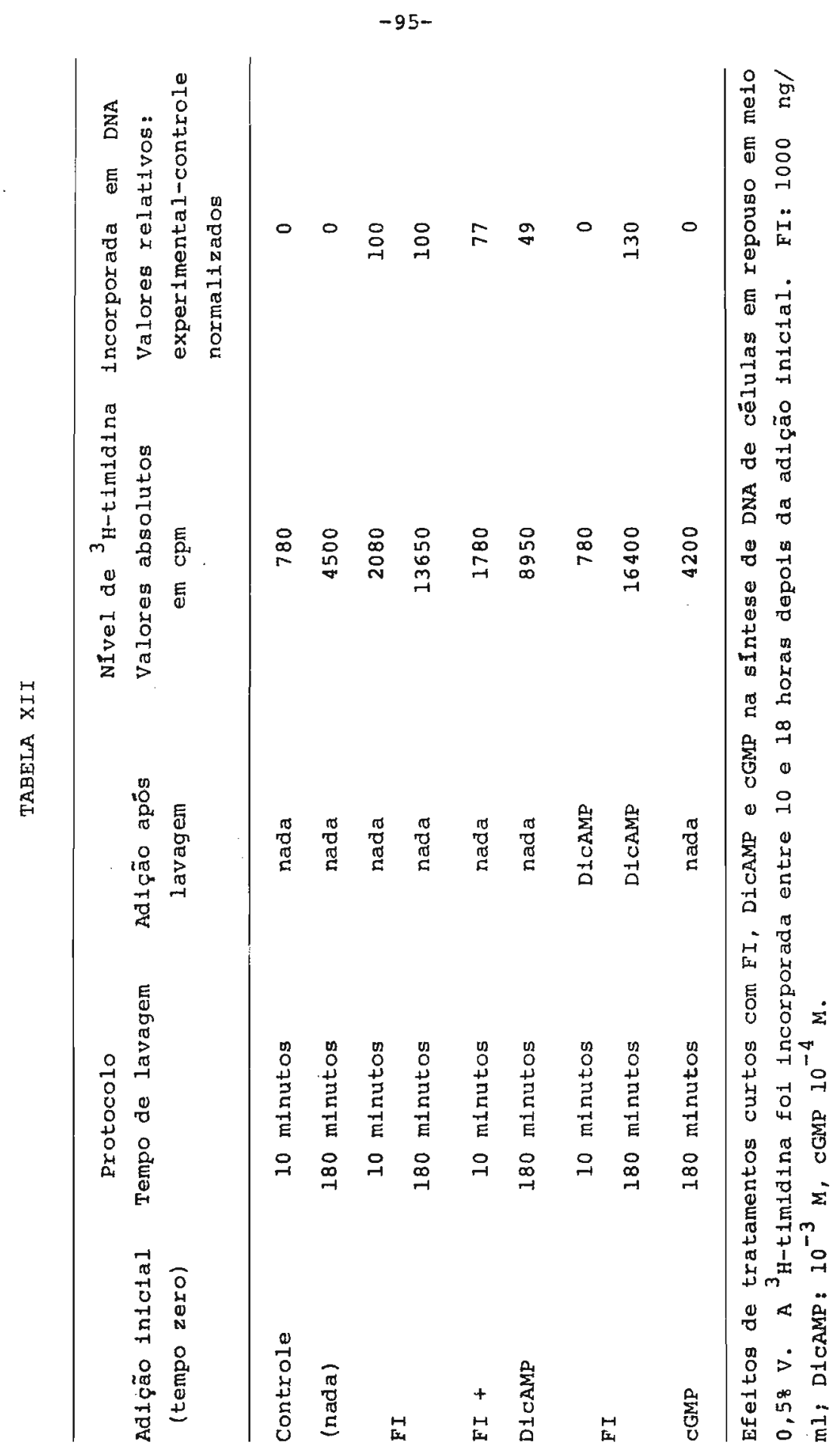


FIGURA 10 - Ensaio de atividade estimuladora da iniclação de sintese de DNA para FI, hidrocortisona e insulina em melo isento de soro. Experiência efetuada segundo o protocolo descrito no texto (Resultados 3). ${ }^{3} \mathrm{H}$-timidina: $10^{-8} \mathrm{M}$; I $\mu \mathrm{C} / \mathrm{ml}$; incorporação por 12 horas (do tempo 12 as 24 horas). 10a: melo com hiorocortisona $100 \mathrm{ng} / \mathrm{ml}$, insulina $50 \mathrm{ng} / \mathrm{ml} e$ quantidades crescentes de FI; 10b: meio com FI $1000 \mathrm{ng} / \mathrm{ml}$ e quantidades crescentes de hidrocortisona; 10c: meio com FI $1000 \mathrm{ng} / \mathrm{ml}$, hidrocortisona $100 \mathrm{ng} / \mathrm{ml}$ e guantidades cres centes de insulina. 


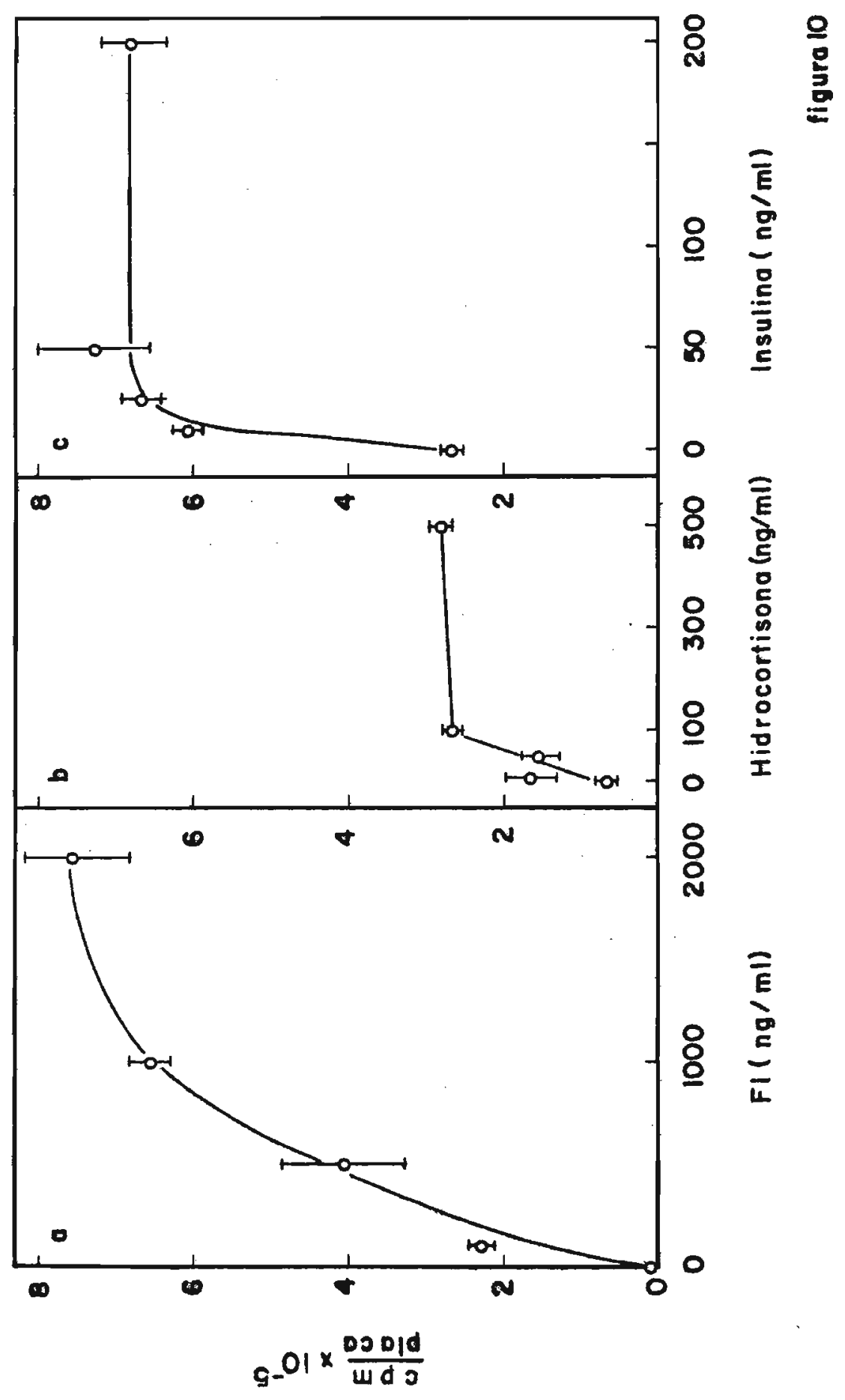


$-98-$

FIGURA 11 - Comparação das atividades de FI e PF em meio 1sento de soro. Protocolo: conforme Figura $10 .{ }^{3}$ H-timidina: $10^{-8} \mathrm{M}, 0,5 \mu \mathrm{C} / \mathrm{ml} . \quad \triangle \triangle \quad \mathrm{PF}$ (fator hipofisário puro,ge nerosamente fornecido por $\mathrm{D}$. Gospodarowicz); 0 mais hiarocortisona $100 \mathrm{ng} / \mathrm{ml}$ e insulina $50 \mathrm{ng} / \mathrm{ml} ; \leadsto \mathrm{CF}$; o- CF mais hidrocortisona $100 \mathrm{ng} / \mathrm{ml}$ e insulina $50 \mathrm{ng} / \mathrm{ml}$. 


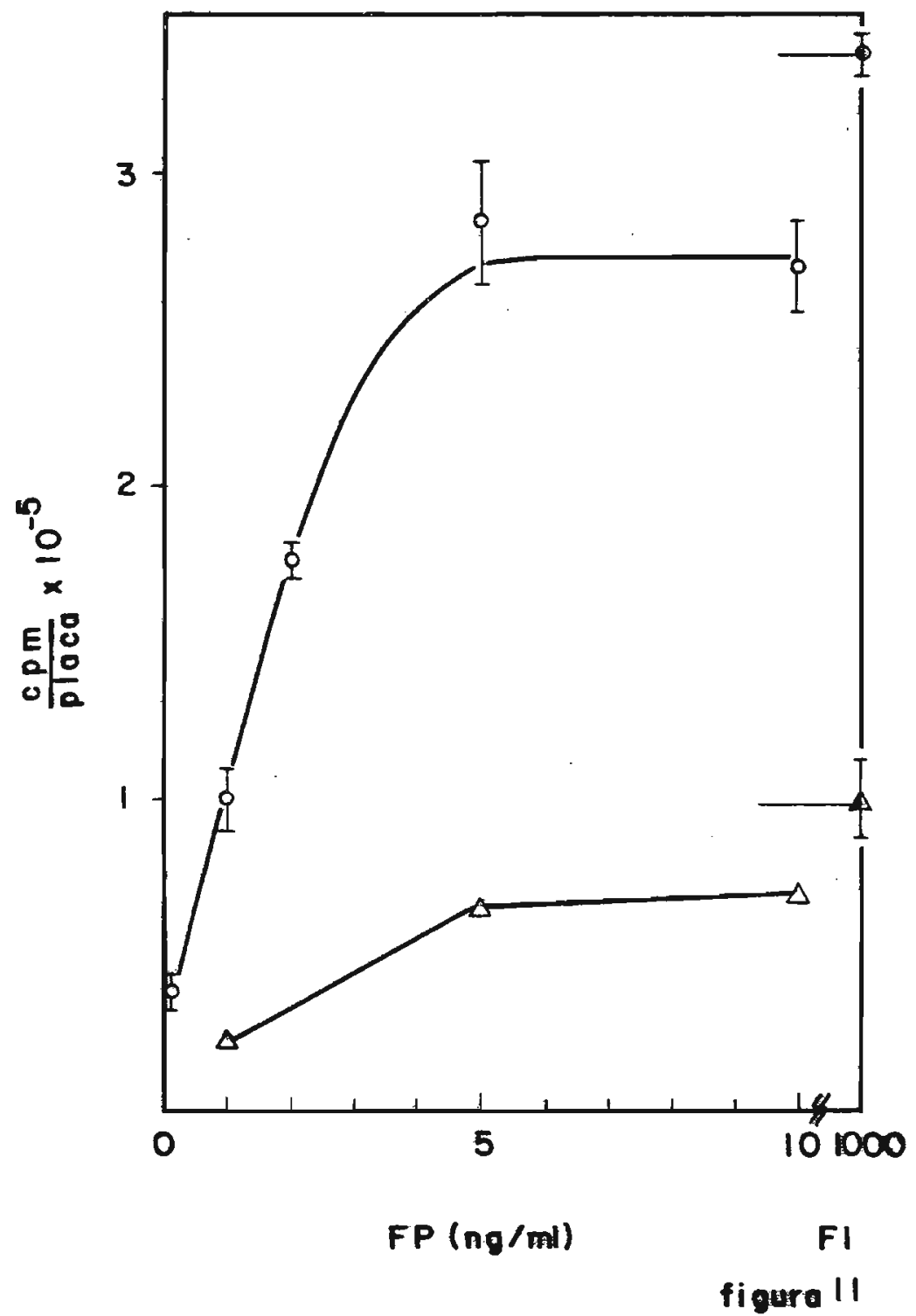


FIGURA 12 - Iniciação de sintese de DNA, "terminação" da divisão celular e sobrevivência em meio isento de soro. As células foran plaqueadas e transferldas para melo sem soro de acordo com o protocolo descrito em Resultados 3 . 12a: pulsos de 20 minutos de ${ }^{3}$ H-timidina; (958), (418) e (08) indicados na figura representam \& de núcleos marca dos, medidos por autorradiografias para 0 pulso de ${ }^{3} \mathrm{H}$-timi dina efetuado no tempo 16 horas. 12b: Contagens de células em "Coulter Counter". 5c: Sobrevivência celular medida pela capacidade de desenvolvimento de colônia (eficiência de plaqueamento); nos tempos indicados as células foram tripsinizadas e aliquotas de cada placa foram ret1radas em condiçōes estēreis; as suspensões de cēlulas foram imediatamente contadas em "Coulter Counter"; após as contagens foram efetuadas diluições apropriadas das ali quotas (recolhidas antes das contagens) e as células foram plaqueadas em meio rico (CFB), em densidades de 250 a 400 cẻlulas/placa; depols de 8 dias de crescimento as colônias foram contadas. O nümero de colónias desenvolvido por placa foi determinado e a razão de colônias por placa sobre o número de células plaqueadas por placa foram lançadas no gráfico em função do tempo. o o controle, sem adições; 0 - FI e hormônios adicionados no tempo zero; $\Delta-\Delta 0,28$ de soro, FI e hormôntos adiclonados nc tempo zero; $4-\lambda$ FI e hormônios no tempo zero e 0,28 de soro a 24 horas; $\square-\square$ FI e normônios no tempo zero e 0,28 de soro a 30 horas. As setas, nos gräficos, ind1cam o tempo de adição de 0,28 de soro de vitelo. 


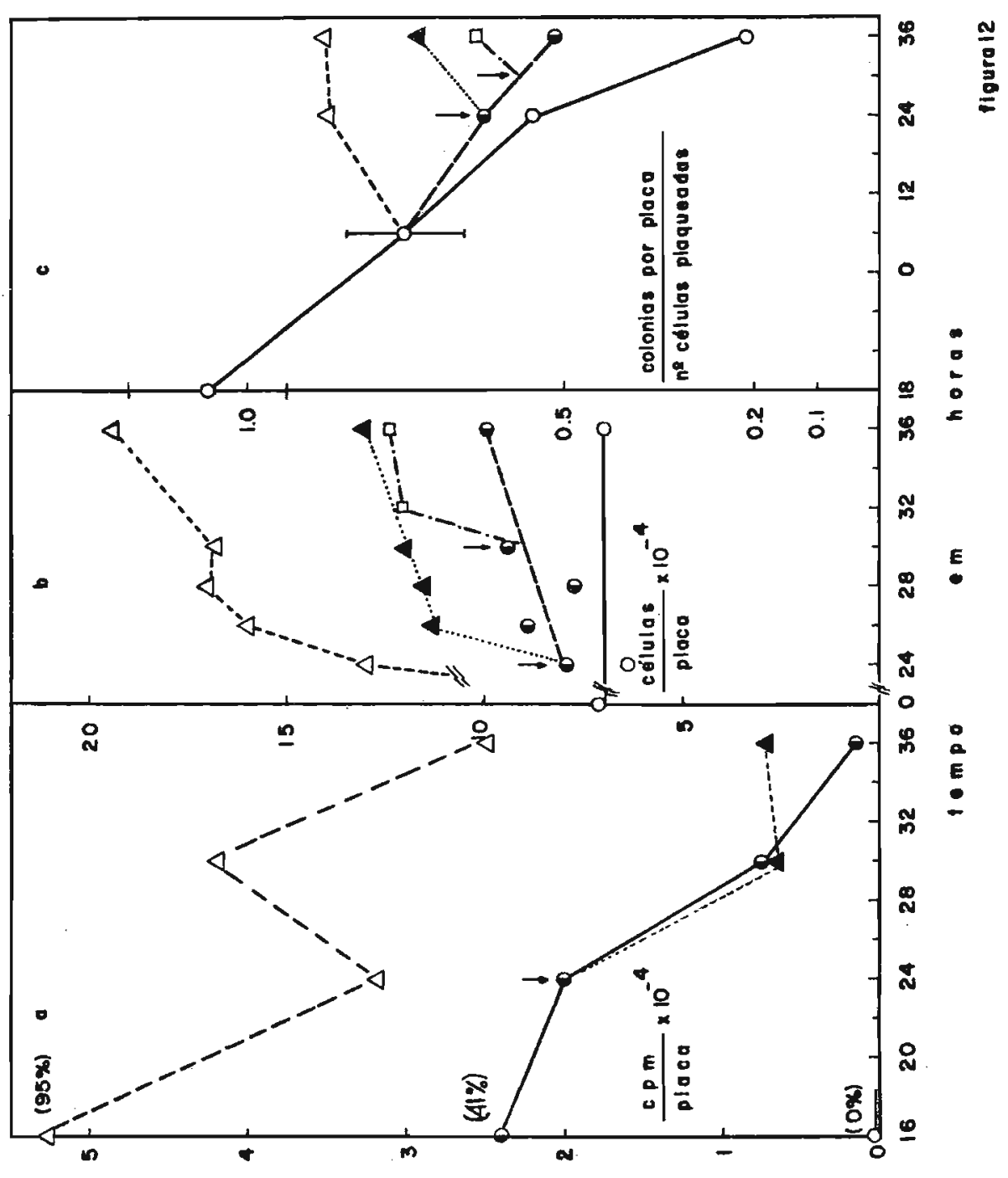


FIGURA 13 - Estimulação da sintese de DNA em células em repouso em $0,58 \nabla$, através de tratamentos curtos com FI. As células foram plaqueadas para repouso em $0,58 \mathrm{~V}$ segundo 0 protocolo indicado em Resultados 3. FI foi adicionado a $1000 \mathrm{ng} / \mathrm{ml}$, no tempo zero; em algumas placas FI foi mantido por todo o tempo da experiência (๑); em outras placas FI foi retirado atravēs de sucção do meio, lavagem das células por sucção cam $0,58 \mathrm{~V}$ por quatro vezes, e finalmen te adicionandio-se meio fresco $0,5 \% \mathrm{~V}$. Tempos de tratamen to com FI: $0--10$ minutos, $\Delta-\Delta \quad 30$ minutos e $\downarrow-\downarrow$ 60 minutos. Controles: $0-0$ sem FI e sem lavagens; $\square-\square$ sem FI, mas com lavagens a 60 minutos. A sintese de DNA foi seguida pela incorporação de ${ }^{3} \mathrm{H}$-timidina $\left(10^{-6} \mathrm{M}, 1 \mathrm{kC}\right.$ ) ml), a qual foi adicionada quatro horas depois da adição de FI e foi mantida durante toda experiência. 


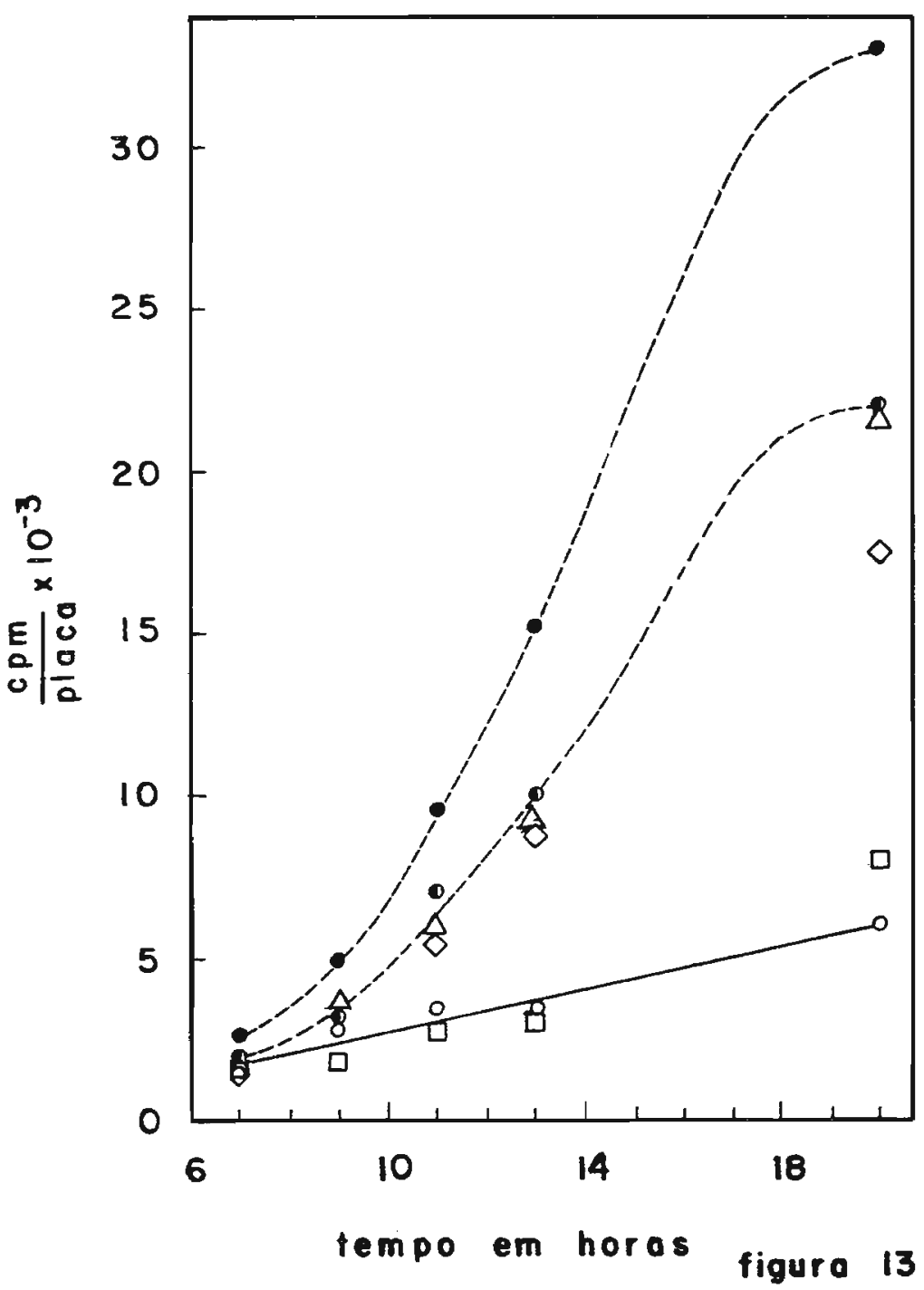


VI. RESUE⿻

A finalidade básica deste trabalho fol o estudo do controle de crescimento e divisão celular em organismos superiores, utilizando cēlulas de mamffero em cultura como modelo experimental. Como os fundamentos conceituais para este tipo de trabalho não tinham, ainda, sido estabelecidos, fol felto um esforço para criar bases doutrinärias sólldas que, adequadamente, fundamentassem este tipo de investigação.

Do ponto de vista teórico, alguns conceitos pre liminares foram sugeridos; os pontos principais sendo: i) 0 estabelecimento de linhagens de células em cultura envolve a seleção clonal de células capazes de crescer nas condlções de cultura; o crescimento depende dos "mecanismos regulatōrios do crescimento", os quais controlam o crescimento da cēIula quando acionados pelos "reguladores extracelulares do crescimento"; os "mecanismos regulatörios" e os "reguladores" são de existência postulada; a seleção de células que exí bem os "mecanismos regulatörios" e que respondem aos "regula dores" deve ser atacada empiricamente, mas alguns principios racionais podem ser adiantados "a priori". il) um modelo pro babilistico de "ciclo celular" fol sugerido; os "reguladores de crescimento" foram definidos no contexto deste modelo; os "mecanismos regulatörios de crescimento" são hipotetica mente colocados entre as reações iniciais de Gl; uma conduta para iniciar o teste experimental das hipōteses propos tas foi estabelecida.

Do ponto de vista experimental, dois problemas foram estudados: i) estabelecimento de linhagens clonadas 
$-105-$

de cēlulas mamărias, a partir de um carcinoma transplantāvel de ratos $\mathrm{AxC}$, o qual era dependente de eströgeno para crescer en animais; as limitações präticas do processo de estabelecimento de linhagens foram estudadas e exemplificadas ex perimentalmente; linhagens clonadas de células foram estabe lecidas, as quais necessitam glucocorticoides, em concen traçōes fisiológicas, para crescer em cultura; os efeitos de CAMP e CGMP sobre o crescimento das cēlulas clonadas foram estudados. ii) fibroblastos de camundongo de linhagem 3T3 foram tomados como modelo experimental para estudar o contro le do crescimento; proteinas de origem hipofisäria, descobertas anteriormente (ARMELIN, 1973), foram experimental mente caracterizadas como "reguladores" do crescimento de 1 broblastos em cultura; foi verificado que a atividade destas proteinas è potenciada por hidrocortisona e insulina, em concentrações fisiolōgicas; as previsōes do modelo de "ciclo celular" proposto concordam com os resultados obtidos, indicando aderēncia do modelo à prātica; foi descoberto que o nivel intracelular de CGMP eleva-se abruptamente no inicio de Gl; experiências com diversos protocolos foram tentadas visando esclarecer o papel de CAMP e CGMP no inïcio de Gl.

O relato apresentado, aparentemente, justifi ca dizer que uma etapa critica do trabalho proposto fol vencida; os conceitos preliminares sugeridos e os resultados apresentados ter implicações bāsicas para a fundamentação biọ quimica da fisiologia celular de mamiferos. 
VII. REFERENCIAS

AARONSON, S.A. E TODARO, G. (1968) - Science, 162: 1024.

ABERCROMBIE, M. e HEAYSMAN, J. (1954) - Exp. Cell Res., 6: 293.

ARMELIN, H.A. (1973) - Proc. Nat. Acad. SC. U.S., 70: 2702.

ARMELIN, H.A. (1974) - In: Biochemical Actions of Hormones,

Vol. III: Ed. G. Litwak (em impressão).

ARMELIN, H.A. A ARMELIN, M.C.S. (1974) - Nature (submetido). ARMELIN, H.A. e SATO, G. (1973) - In: World Symposium on

"Model Studies in Chemical Carcinogenesis"; Ed. E. Farber

chapter 24, pāg. 483; Marcel Dekker Inc., Nova York.

ARMELIN, H.A.; NISHIKAWA, K. e SATO, G. (1974) - In: Control

of Proliferation in Animal Cells; Ed. B. Clarkson and

R. Baserga, Vol. I, pāg. 97, Cold spring Harbor Press, № va York.

ASUA, I.J.; SURIAN, E.; FIAWIA, M. e TORRES, H.N. (1973) -

Proc. Nat. Acad. Sc. U.S., 70: 1388

AUGUSTI-TOCCO, G. e SATO, G. (1969) - Proc. Nat. Acad. Sc.

U.S., 64: 311 .

BABAD, H. e BASSID, W.z. (1966) - J. Biol. Chem., 241: 2672.

BASERGA, R. (1968) - Cell Tissue Rinet., 1: 167.

BASERGA, R.; COSTLOW, M. e ROVERA, G. (1973) - Fed. Proc.,

32: 2115 .

BENDA, P.V.; LIGHTBODY, J.; SATO, G.; LEVINE, L. e SWEET, V.

(1968) - Science, 161: 370 .

BISKIND, M.S. e BISKIND, G.R. (1944) - Proc. Soc. Exp. Biol.

Med., 55: 176 .

BROWN, J. (1968) - Exp. Cell Res, 52: 565 . 
BUONASSISI, V.; SATO, G. e COHEN, A. (1962) - Proc. Nat. Acad. Sc. 0.S., 48 : 1184 .

BURGER, M. (1971) - In: "Ciba Fdn. Symp. Growth Control in Cell Cultures"; Eds. G. Wolstenholme and J. Knight, Churchill Livingston, London.

BURGER, M.; BOMBIK, B.; BRECKENRIDGE, B. e SHEPPARD, J.

(1973) - Nature New Biol., 239: 161.

BURGUS, R.; DUNN, T.; DESIDERIO, D.; VALE, W. e GULIEMIN, R.

(1969) - C.R. Acad. Sci. Ser. D, 269: 1870.

BUTCHER, R.W. e SUTHERLAND, E.W. (1962) - J. Biol. Chem., 237:

1244 .

CECCARINI, C. e EAGLE, E. (1971a) - Proc. Nat. Acad. Sc. U.s., 68: 229 .

CECCARINI, C. e EAGLE, H. (197lb) - Nature New Biology, 233:

CLARKE, G.; STOKER, M.G.P.; LUDLOW, A. e THORNTON, M. (1970) Nature, 227: 798 .

CHEN, R.F. (1967) - J. Biol. Chem., 242: 173.

COHEN; S. (1962) - J. Biol. Chem., 237: 1555.

CORVOL, M.; MALEMUD, C.J. e SOKOLOFF, I. (1972) - Endocrinology, 90: 262 .

CUNNINGHAM, D. A PARDEE, A. (1969) - Proc. Nat. Acad. Sc. U.S., 64: 1049 .

CUNNINGHAM, D. e REMO, R. (1973) - J. Biol. Chem., 248: 6282. CUNNINGHAM, D.; THRASH, C. e GLYNN, R.D. (1974) - In: "Control

of Proliferation in Animal Cells"; Eds. B. Clarkson and R.

Baserga, Vol. I, Cold Spring Harbor Press, Nova York.

DULBECCO, R. (1970) - Proc. Nat. Acad. Sc. U.S., 67: 1214.

DULAECCO, R. (1971) - In: "Ciba Fdn. Symp. Growth Control in

Cell Cultures"; Eds. G. Wolstenholme and J. Rnight, Churchill Livingston, Londor. 
DULAR, N.C. e TEMIN, H.M. (1973) - J. Cell Physiol., 81. 153. ESTENSEN, R.D.; HADDEN, J.; HADDOX, M.R. e GOLDBERG, N.D.

(1974) - In: "Control of Proliferation in Animal Cells";

Eds. B. Clarkson and R. Baserga, Vol. I, Cold Spring Har-

bor Press, Nova York.

FLECK, A. e MUNRO, H. (1962) - Blochim. Blophys. Acta, 55: 571. FURTH, J. (1968) - In: "Thule International symposia"; Eds.

A. Engel e T. Larsson; Nordiska Bokhandelns Förlag, Estocol mo, vol. 2, päg. 131 .

FURTH, J. (1970) - In: "Proc. 10 th Int. Cancer Congress"; Eds.

R. Clark, R. Cumley, J. McCay e M. Copeland, Vol. I, pág.

272.

GOSPODAROWICZ, D. (1974) - Nature, 249: 123 .

GOSPODAROWICZ, D. E PAPKOFF, H. (1966) - Endocrinology, 80:

699.

GREEN, H. (1974) - In: "Control of Proliferation in Animal

Cells"; Eds. B. Clarkson and R. Baserga, Vol. I, Cold Spring Harbor Press, Nova York.

HADDEN, J.W.; HADDEN, E.M.; HADDOX, M. A GOLDBERG, N.D. (1972) -

Proc. Nat. Acad. Sc. U.S., 69: 3024.

HALI, K. e VAN WYK, J. (1973) - In: "Current Topics in Experi-

mental Endocrinology" Ed. Martini and James, Academic Press, Nova York.

HARTWELL, L.H. (1971) - J. MOl. BiOl., 59: 183.

BAYFLICK, L. (1965) - Exp. Cell Res.., 37: 614 .

HAYFIICK, L. E MOORHEAD, P.S. (1961) - EXp. Cell Res., 25: 585.

HERSHKO, A.; MAMONT, P.; SHIEIDS, R. e TOMKINS, G.M. (1971) -

Nature New B101., 232: 206.

hollenberg, M. e CUATrecasas, P. (1973) - Proc. Nat. Acad. Sc.

v.S., 70: 2964 . 
HOLLEY, R.W. (1972) - Proc. Nat. Acad. Sc. U.S., 69: 2840. HOLLEY, R.W. e KIERNAN, J. (1968) - Proc. Nat. Acad. SC. U.S., 60: 300 .

HOLLEY, R.W. e KIERNAN, J. (1971) - In: "Ciba Fan. Symp.

Growth Control in Cell Cultures"; Eds. G. Wolstenholme and

J. Knight, Churchill Livingston, London.

HOIIEY, R.W. E RIERNAN, J. (1974) - Proc. Nat. Acad. Sc. U.S.,

(in press).

HOWARD, A. e PELC, S.R. (1952) - Heredity. Suppl. $\underline{6}: 261$.

HSIE, A. e PUCK, T.T. (1971) - Proc. Nat. Acad. Sc. U.S., 68:

358 .

IGLESIAS, R. (1970) - In: "Proc. $10^{\text {th }}$ Int. Cancer Congress";

Eds. R. Clark, R. Cumley, J. McCay and M. Copeland, Vol. I, pāg. 300 .

JAINCHILL, J.L. e TODARO, G. (1970) - Exp. Cell Res., 59: 137.

JOHNSON, G.; FRIEDMAN, R. e PASTAN, I. (1971) - Proc. Nat.

Acad. Sc. U.S., 68: 425 .

KLEVECZ, R.R. (1969) - J. Cell Biol., 43: 207.

KLEVECZ, R. e RUDDLE, F. (1968) - Science, I59: 634 .

RIEVECZ, R.; KAPP, I. e REMINGTON, J.A. (1974) - In: "Control

in Proliferation of Animal Cells"; Eds. B. Clarkson and R.

Baserga, Vol. I, Cold Spring Harbor Press, Nova York.

LAJTHA, L.G. (1963) - J. Cell Physiol., 62: 143.

LIPTON, A.; KLINGER, I.; PAUL, D. e HOLLEY, R.W. (1971) - PrOC.

Nat. Acad. SC. U.S., 68: 2799.

LOWRY, O.; ROSEBROUGH, J.; FARR, A.; RANDELL, R. (1951) - J.

Biol. Chem., 193: 265.

LYONS, W.R.; LI, C.H. E JOHNSON, R.E. (1958) - Rec. Progr.

Hormone Res., 14: 219.

MAZIA, D. (1974) - Sci. Amer:, 230: 54 .

MIIGRAM, E. e BAULIED', E. (1969) - Biochim Biophys. Acta, 194:602. 


$$
-110-
$$

MITCHISON, J.M. (1971) - The Biology of the cell Cycle, Cambridge University Press, Cambridge.

MURAD, E.; MaNGANIELLO, V. e VAUGHN, M. (1971) - Proc. Nat.

Acad. Sc. U.S., 68: 736 .

NACHTWEY, D. E CAMERON, I. (1968) - In: "Methods in Cell

Physiology"; Ed. D.M. Prescott, Vol. 3, pāg. 213, Academic Press, Nova York.

NARDONE, R.M.; TODD, J.; GONZALEZ, P. e GAFFNEY, E. (1965) Science, 149: 1100 .

NICOLSON, G.I. (197I) - Nature New Biol., 233: 244.

NICOLSON, G.I. (1973) - Nature New Biol., 243: 218.

NISHIKAWA, R.; ARMELIN, H.A. e SATO, G. (1974) - Proc. Nat.

Acad. Sc. U.S., (in press).

OTTEN, J.; JOHNSON, G. e PASTAN, I. (1971) - Biochem. Biophys.

Res. Comm., \$4: 1192 .

OTTEN, J.; BADER, J.; JOHNSON, G. E PASTAN, I. (1972) - J.

Biol. Chem., 247: 1632 .

PAPROFF, H.; GOSPODAROWICZ, D.; CANDIOTTI, A. e LI, C.H.

(1965) - Arch. Biochem. Biophys., 111: 431.

PAPKOFF, H.; GOSPODAROWICZ, D. e II, C.H. (1967) - Arch. BiOche Biophys., 120: 434.

PAUL, D.; LIPTON, A. e KIINGER, I. (1971) - Proc. Nat. Acad. Sc., U.S., 68: 2799 .

POLIACK, R.E.; GREEN, H. e TODARO, G. (1968) - Proc. Nat. Acad. Sc. U.S., 60: 126 .

PUCR, T.T. e KAO, F. (1967) - Proc. Nat. Acad. Sc. U.S., 58: 1227.

ROBISON, G.A.; BUTCHER, R. e SUTHERLAND, E.W. (1971) - CYCIIC

AMP, Academic Press, Nova York. 
SALMON, W.D. e DADGHADAY, W. (1957) - J. Lab. and Clin. Med., 49: 825 .

SAMBROOR, J. (1972) - Adv. Cancer Res., 16: 141.

SAMBROOR, J.; SHARP, P. e KELLER, W. (1972) - J. MOl. BiO1.,

70: 57 .

SANFORD, R.R. (1968) - Nat. Cancer Inst. Monograph, 26: 387.

SATO, G.; ZAROFF, I. e MILIS, S.E. (1960) - Proc. Nat. Acad.

Sc. O.S., $46: 963$.

SEFTON, B.M. e RUBIN, H. (1971) - Proc. Nat. Acad. Sc. U.S.,

68: 3154 .

SHEPPARD, J. (1971) - PrOC. Nat. Acad. SC. U.S., 68: 1316.

SHIN, S.; YASUMURA, Y. e SATO, G. (1968) - Endocrinology, 82:

614 .

SILAGI, S. (1971) - Proc. Nat. Acad. Sc. U.S., 68: 1402.

SMITH, J.A. e MARTIN, L. (1973) - Proc. Nat. Acad. Sc. J.S.,

70: 1263 .

STEEL, G.G. (1972) - Cell Tissue kinet., $\underline{5}: 87$.

STEINER,A.; PARKER,C. e KIPNIS,D. (1972) - J.Biol.Chem, 247:1106.

STUDZINSKI, G.; GIERTHY, J.F. e CHOLON, J. (1973) - In Vitro,

8: 466 .

TASHJIAN, A.; YASUMURA, Y.; LEVINE, L.; SATO, G. e PARKER, M.

(1968) - Endocrinology, 82: 342 .

TEMIN, H.M. (1967) - J. Cell physiol., 69: 377.

TEMIN, H.M. (1971) - J. Cell Physiol., 78: 161.

TOBEY, R.; GURIEY, I.; HILDEBRAND, C.; RATLIFF, R. e WALTERS,

R. (1974) - In: "Control of Proliferation in Animal Cells";

Ed. B. Clarkson and R. Baserga, Vol. I, Cold Spring Harbor

Press, Nova York.

TODARO, G. E GREEN, H. (1963) - J. Cell Biol., 17: 199.

TODARO, G. E GREEN, H. (1964) - Virology, 23: 117. 
TODARO, G.; GREEN, E. e GOLDBERG, B. (1964) - proc. Nat. Acad.

Sc. U.S., 51: 66 .

TODARO, G.; LAZAR, G. e GREEN, H. (1965) - J. Cell Comp.

Physiol., 66: 325 .

UTENE, R. (1973) - Acta Endocsinologica Suppl. 175: 1.

WALTERS, R.; TOBEY, R. e RATIIFF, R. (1973) - BiochLm. BIOphys.

Acata, 319: 336 .

WEBER, M.J. (1973) - J. Bio1. Chem., 248: 2978.

WESTPHAL, U. (1967) - Arch. Blochem. Blophys., 118: 556.

WILIIAMS-ASHMAN, H.G.; PEGG, A.E. e LOCKWOOD, D.H. (1969) -

Adv. Enz. Regul., 7: 291.

WIILINGHAM, M.C.; JOHNSON, G.S. e PASTAN, I. (1972) - Biochem.

Biophys. Res. Comm., 48: 743 .

YAFFE, D. (1968) - Proc. NäE. Acaa. SC. U.5., 61: 477.

YASUMURA, Y.; BUONASSISI, V. e SATO, G. (1966a) - Cancer Res.,

26: 529 .

YASUMURA, Y.; TASHJIAN, A. e SATO, G. (1966b) - Sc1ence, 154:

1186. 
VIII. ABREVIATURAS

Fases do ciclo celular

G1: "gap" ou Intervalo existente entre o fim da mitose e o inicio da sintese de DNA

S: intervalo da sintese de DNA

G2: "gap" ou intervalo existente entre o fim da sintese de DNA e o começo da mitose

M: mitose

Hormôntios e outros fatores

ACTH: hormōn1o estimulador da cortex adrenal

FI: mistura de proteinas hipofisārias diferentes dos hormônios proteicos conhecidos, que estimulam crescimento de diversos tipos de células en cultura

FP: proteina pura que estimula o crescimento de fibroblas tos en cultura

FSH: hormônio estimulador do foliculo

GH: hormônio de crescimento

LH: hormōnio Iuteinizante

NIH-IH-B8: preparação impura de LH bovino, fornecida pelos National Institutes of Health, EUA; partida no 8 TSH: hormônio estimulador da tirốide

uinhagens de animais

Balb/c: camundongos "geneticamente puros"

AxC: ratos "geneticamente puros"

Linhagens de células e virus

$3 T 3$ - fibroblastos de camundongo suiço "normais" (TODARO e GREEN, 1963) 
6T6: Fibroblastos de camundongo suiço "expontaneamente trans formados" (TODARO e GREEN, I963)

SV3T3: fibroblastos $3 T 3$ transformados pelo virus SV40

Balb/c 3T3: fibroblastos de camundongo Balb/c, "normais" (AARONSON E TODARO, 1968)

SV40: "simian virus 40", virus oncogênico que crescem permis sivamente em células de macaco

Meios de cultura

DME: meio quimicamente definido, cuja composição é a do meio minimo de EAGLE e segundo modificação de DULBECCO

CFB: meio composto por $85 \%$ de DME, $12,5 \%$ de soro de cavalo e 2,58 de soro de feto bovino; medidos en volume 108V: meio composto por 908 de DME e $10 \%$ de soro de vitelo 10\%VC: meio composto por $90 \%$ de DME e $10 \%$ de soro de vitelo extraido com carvão ativo

MBCS : meio com baixa concentração de soro (menos que 1\%)

Nucleosidios e nucleotidios

UDP: uridina-5'-difosfato

FUDR: 5-fluor-2'-desoxiuridina

BUDR: 5-bromo-2'-desoxiuridina

cCMP: adenosina ciclica-3',5'-monofosfato

cGMP: guanosina cỉclica-3',5'-monofosfato

DicAMP: $\mathrm{N}^{6} \mathrm{O}^{2}$-dibutiril adenosina ciclica-3',5'-monofosfato

Diversos

DMSO: dimetil sulföxido

TCA: äcido tricloro acētico

EP: eficiência de plaqueamento

CMC: carboximetil celulose 